UNIVERSIDADE DE SÃO PAULO

FACULDADE DE FILOSOFIA, LETRAS E CIÊNCIAS HUMANAS

DEPARTAMENTO DE LETRAS ORIENTAIS

BRUNO HISSATUGU

\title{
Retratos maternos: fotografias e cartas de imigrantes japoneses em São Paulo
}


UNIVERSIDADE DE SÃO PAULO

FACULDADE DE FILOSOFIA, LETRAS E CIÊNCIAS HUMANAS

DEPARTAMENTO DE LETRAS ORIENTAIS

\title{
Retratos maternos: fotografias e cartas de imigrantes japoneses em São Paulo
}

\author{
Bruno Hissatugu \\ Dissertação apresentada ao Programa de Pós- \\ Graduação em Língua, Literatura e Cultura \\ Japonesa do Departamento de Letras Orientais \\ da Faculdade de Filosofia, Letras e Ciências \\ Humanas, da Universidade de São Paulo, para \\ obtenção do título de Mestre.
}

Orientador: Prof. Dr. Koichi Mori 
HISSATUGU, Bruno. Retratos maternos: fotografias e cartas de imigrantes japoneses em

São Paulo. Dissertação apresentada ao Programa de Pós-Graduação em Língua, Literatura e Cultura Japonesa do Departamento de Letras Orientais da Faculdade de Filosofia, Letras e Ciências Humanas, da Universidade de São Paulo, para obtenção do título de Mestre, 2012.

Aprovado em:

Banca examinadora:

Prof. dr.:

Instituição:

Julgamento:

Assinatura:

Prof. dr.:

Instituição:

Julgamento:

Assinatura:

Prof. dr.:

Instituição:

Julgamento:

Assinatura: 
Agradecimentos

Orientador prof. dr. Koichi Mori

Patrícia Tamiko Izumi, Luzia Miyuki Teruya e Kátia Müller (CEJAP - USP)

Tatiana Vasconcelos, Museu Paulista

Marcos de Souza Persici, Museu Histórico da Imigração Japonesa no Brasil

Marli Marcondes, Centro de Memória da Unicamp

Famílias Hara, Hirata, Hisatsugui, Irino, Matsuyama, Nagano, Okazaki, Sakasegawa,

Shinmyozu, Tomita, Umeki, Uehara

Maurício Medeiros Shirakawa

Takashi Kayano

Diógenes Kozo Shitara

Aos professores Mario Celso Ramiro de Andrade, Rose Satiko Gitirana Hikiji, Marcos

Antonio de Moraes, Madalena Natsuko Hashimoto Cordaro, Luiza Nana Yoshida, Junko Ota, Universidade de São Paulo

Aya Hikosaka, Hideko Wada, Yurie Watanabe, prof. dr. Hidekazu Sensui, dr. Kouichiro

Kobayashi, diretor Shigeru Tagami, Universidade de Kanagawa

Elena Yamagata, JICA Yokohama

Naoki Tanaka, Foundation Nippon Rikkokai

Prof. dr. Yuji Kurose, Universidade Internacional de Kagoshima

Miho Nagai, Shibusawa Memorial Museum

Mestres Makoto e Fumie Nishida, ACAM - FEPAI, Brasil

Mestres Hiroshi Isoyama e Shigemi Inagaki, Ibaraki Shibu Dojo - Aikikai Foundation, Japão

Gretchen Seichrist \& Iris

Aos meus pais e meu irmão 
Resumo: A pesquisa que realizei se concentrou em minha avó materna Akie Sakasegawa Matsuyama e suas famílias: seus pais e irmãos (Sakasegawa) e seu marido e fillhos (Matsuyama). Não conheci meu avô Hideo Matsuyama. Talvez este estudo seja a maneira que encontrei de conhecer um pouco de sua história. Concentrei-me principalmente no espólio de Akie Sakasegawa Matsuyama, que compreende cartas, fotos avulsas e álbuns fotográficos, e na coleção fotográfica de sua mãe, Ine Narita Sakasegawa. Conduzi entrevistas não estruturadas, com fotografias, com diversos membros de sua família, nuclear e estendida, no Brasil e no Japão. Através desse material, pude vislumbrar os meios pelos quais as relações familiares foram mantidas após a imigração para o Brasil. O principal intuito do trabalho foi questionar o papel da fotografia nas trocas interpessoais entre as famílias no Japão e no Brasil. $\mathrm{E}$, dessa forma, entender as ligações entre os retratos fotográficos e a noção de identidade que os imigrantes tinham de si mesmos. Por se tratar de um estudo sobre a família, a minha família, tentei utilizar metodologias concernentes à antropologia reflexiva, ou seja, procurei deixar claro que sou eu quem faz as reflexões e escreve sobre elas. Assim, muitos pontos podem dar margens à discórdia, muitas afirmações são escolhas que tive de fazer em função do texto. Uma vez que este estudo se refere à vida íntima de membros de minha família que, em sua maioria, não tive o privilégio de conhecer, boa parte do texto está aberta a outras interpretações. Tentei não impor minha visão demasiadamente, procurei estar aberto o suficiente para ouvir sem preconceitos o que os informantes me comunicaram. Busquei, enfim, seguir os rastros deixados por meus antepassados e ser fiel ao que pude vislumbrar. Este é um trabalho cuja intenção é preservar a memória das histórias e dos afetos compartilhados pelos imigrantes japoneses e suas famílias. Através de materiais permeados por amor e amizade, fotos e cartas, tentei compreender as relações íntimas entre os imigrantes de minha família materna.

Palavras-chave: Fotografia - Antropologia Visual - História

Famílias - Retratos de imigrantes japoneses - São Paulo 


\begin{abstract}
This research focused on my maternal grandmother, Akie Sakasegawa Matsuyama, and her families: her parents and siblings (Sakasegawa) and her husband and children (Matsuyama). I did not know my grandfather, Hideo Matsuyama. Maybe this study is a way I found to know a little about his life history. My main focus was on the state of Akie Sakasegawa Matsuyama, encompassing letters, photographs and photographic albums, and on the photographic collection of her mother, Ine Narita Sakasegawa. I conducted several nonstructured interviews, using photographs, with members of her family, nuclear and extended, in Brazil and in Japan. All this material helped me to understand the means by which the familial relationships were maintained after the migration to Brazil. The main purpose of this work was to question the roles of photography in the interpersonal exchanges between the families in Japan and in Brazil, and try to figure out the liaisons between photographic portraits and the sense of identity the immigrants had of themselves. Once this is a study about the family - my family - I felt the need to make use of methodologies within reflexive anthropology. I wanted to make it clear that I'm the one thinking about these issues and writing about them. In this aspect, in many instances, there is room for disagreements; many of the statements I support are choices I had to make in order to write a somewhat coherent text. Because this is a study about the intimate life of members of my family I did not have the chance to meet or interview, a lot of my assumptions are open to interpretation.

Nonetheless, I tried not to force my points of view in an exaggerated fashion, I wanted to be open enough to listen without preconceptions what the interviewees told me. Thus, I tried to follow the threads left by my ancestors and be faithfull to everything I could find. The objective of this work is to preserve the memory of the histories and endearments shared by the Japanese immigrants and their families. Using materials that are fulfilled with love and friendship - photos and letters - I tried to comprehend the intimate relationships between the immigrants and their families.
\end{abstract}

Keywords: Photography - Visual Anthropology - History Family - Portrait of Japanese immigrants - São Paulo 


\section{Lista de ilustrações}

Figura 1 (p. 34). Fotógrafos desconhecidos. Página 1 (álbum 1) com seis fotos. Kagoshima, Japão. ca. 1930. Gelatina. Dimensões da página 34 x 25 cm. Espólio da família Matsuyama. Figura 2 (p. 35). Fotógrafo desconhecido. Página 2 (álbum 1) com uma foto. Kagoshima, Japão. 1915. Gelatina. Dimensões da página 34 x 25 cm. Espólio da família Matsuyama.

Figura 3 (p. 36). Foto estúdio de Antonio Watanabe (foto central) e fotógrafos desconhecidos (oito fotos laterais). Página 3 (álbum 1). Araçatuba, 1932 (foto central) Lins, ca. 1950 (fotos laterais). Gelatina. Dimensões da página 34 x 25 cm. Espólio da família Matsuyama. Figura 4 (p. 37). Fotógrafo desconhecido. Página 4 (álbum 1) com uma foto. São Paulo. 1950. Gelatina. Dimensões da página 34 x 25 cm. Espólio da família Matsuyama. Figura 5 (p. 38). Fotógrafos desconhecidos. Página 7 (álbum 1) com cinco fotos. Avanhandava e Lins, SP. ca. 1940. Gelatina. Dimensões da página 34 x 25 cm. Espólio da família Matsuyama.

Figura 6 (p. 39). Estúdio Foto Ueno (para as três fotos maiores) e fotógrafo desconhecido (3 x 4). Página 9 (álbum 1) com quatro fotos. São Paulo. ca. 1950. Gelatina. Dimensões da página 34 x $25 \mathrm{~cm}$. Espólio da família Matsuyama.

Figura 7 (p. 40). Fotógrafos desconhecidos. Página 11 (álbum 1) com sete fotos. São Paulo. ca. 1950. Gelatina. Dimensões da página 34 x 25 cm. Espólio da família Matsuyama. Figura 8 (p. 41). Fotógrafo desconhecido. Página 12 (álbum 1) com uma foto. Registro, SP. 1925. Gelatina. Dimensões da página 34 x 25 cm. Espólio da família Matsuyama.

Figura 9 (p. 42). Fotógrafos desconhecidos. Página 13 (álbum 1) com três fotos. Avanhandava, SP. ca. 1940. Gelatina. Dimensões da página 34 x 25 cm. Espólio da família Matsuyama. 
Figura 10 (p. 43). Fotógrafo Hideo Matsuyama. Página 15 (álbum 1) com cinco fotos. Avanhandava, SP. 1938. Machado de Melo, SP. ca. 1940. Gelatina. Dimensões da página 34 x $25 \mathrm{~cm}$. Espólio da família Matsuyama.

Figura 11 (p. 44). Fotógrafo desconhecido. Página 17 (álbum 1) com uma foto. Guararapes, SP. 1933. Gelatina. Dimensões da página 34 x 25 cm. Espólio da família Matsuyama.

Figura 12 (p. 45). Fotógrafos desconhecidos. Página 19 (álbum 1) com seis fotos. Kagoshima, Japão. ca. 1930. Gelatina. Dimensões da página 34 x $25 \mathrm{~cm}$. Espólio da família Matsuyama.

Figura 13 (p. 46). Fotógrafo desconhecido. Página 20 (álbum 1) com uma foto. Machado de Melo, SP. 1940. Gelatina. Dimensões da página 34 x 25 cm. Espólio da família Matsuyama. Figura 14 (p. 47). Fotógrafos desconhecidos. Página 21 (álbum 1) com três fotos. Kagoshima, Japão. ca. 1930. Gelatina. Dimensões da página 34 x 25 cm. Espólio da família Matsuyama.

Figura 15 (p. 48). Fotógrafos desconhecidos. Página 23 (álbum 1) com sete fotos. Kagoshima, Japão. 1907. Machado de Melo, SP. ca. 1930. São Paulo. 1954. Gelatina. Dimensões da página 34 x $25 \mathrm{~cm}$. Espólio da família Matsuyama.

Figura 16 (p. 49). Fotógrafo desconhecido (foto de grupo) e Hideo Matsuyama (foto de canto). Página 30 (álbum 1) com duas fotos. Avanhandava, SP. 1941. Gelatina. Dimensões da página 34 x $25 \mathrm{~cm}$. Espólio da família Matsuyama.

Figura 17 (p. 50). Fotógrafo Hideo e Satiko Matsuyama. Página 9 (álbum 2) com seis fotos. Lins, SP. ca. 1950. Gelatina. Dimensões da página 28 x $20 \mathrm{~cm}$. Espólio da família Matsuyama.

Figura 18 (p. 51). Fotógrafos desconhecidos. Página 11 (álbum 2) com seis fotos. São Paulo. ca. 1950. Gelatina. Dimensões da página 28 x $20 \mathrm{~cm}$. Espólio da família Matsuyama. 
Figura 19 (p. 52). Fotógrafos Hideo e Satiko Matsuyama. Página 15 (álbum 2) com seis fotos. Lins, SP. ca. 1950. Gelatina. Dimensões da página 28 x $20 \mathrm{~cm}$. Espólio da família Matsuyama.

Figura 20 (p. 53). Fotógrafos desconhecidos. Página 29 (álbum 2) com três fotos. Lins, SP. ca. 1950. Gelatina. Dimensões da página 28 x $20 \mathrm{~cm}$. Espólio da família Matsuyama.

Figura 21 (p. 66). Fotógrafo desconhecido. "Família Matsuyama. Kojiro, Kesa, Hiroshi e criança”. Kagoshima, Japão. ca. 1930. Gelatina. 10 x 8 cm. Espólio da família Matsuyama Figura 22 (p. 67). Photographia Mattos (Praça Mauá, 45). “Hideo Matsuyama”. Santos, SP. ca. 1920. Gelatina. 13, 5 x 8, 5 cm. Espólio da família Matsuyama.

Figura 23 (p. 68). Foto estúdio de Antonio Watanabe. "Akie Sakasegawa Matsuyama - foto de casamento". Araçatuba, SP. 1932. Carte-postale. 13, 5 x 8, 5 cm. Espólio das famílias Matsuyama e Sakasegawa.

Figura 24 (p. 69). Fotógrafa Satiko Matsuyama. "Hideo, Akie e Luiz Masao Matsuyama". Lins, SP. 1956. Gelatina. 6 x 4 cm. Espólio das famílias Matsuyama e Sakasegawa. Figura 25 (p. 70). Fotógrafa Satiko Matsuyama. "Família Matsuyama". No verso, lê-se, em português: “Toshio, Hamako, Lauro (sic.), Luci, Onório, Akie, Luiz Masao, Hideo”. São Paulo, 1960. Gelatina.13 x 8 cm. Espólio das famílias Matsuyama e Sakasegawa.

Figura 26 (p. 71). Fotógrafo desconhecido. "Família Matsuyama". No verso, lê-se, em japonês: "Fumi, Mutsuko, Mayoshi, Reiko, Masako, Yoriko, e primo mais velho de Fumi". Kagoshima, Japão. ca. 1950. Gelatina. 12, 5 x 8, 5 cm. Espólio da família Matsuyama. Figura 27 (p. 72). Fotógrafo desconhecido. "Ichiko Matsuyama”. Kumamoto, Japão. ca. 1960. Gelatina. 8 x 5, 5 cm. Espólio da família Matsuyama.

Figura 28 (p. 73). Fotógrafo desconhecido. "Tomoko Matsuyama, sua mãe Masue e cão". Kagoshima, Japão. 1965. Gelatina. 9 x 6 cm. Espólio da família Matsuyama. 
Figura 29 (p. 74). Fotógrafo Norio Shinmyozu. "Fuyoko e Makoto Shinmyozu”. Kagoshima, Japão. 1964. Gelatina.9 x 6 cm. Espólio da família Matsuyama.

Figura 30 (p. 75). Fotógrafo Hideo Matsuyama. “Casa”. Em português, lê-se, na frente: "Construção NOB, casa para chefe da divisão Bauru", e, no verso: "Carpintaria cargo do enc. Hideo Matsuyama”. Bauru, SP. ca. 1940. Gelatina. 8, 5 x $6 \mathrm{~cm}$. Espólio da família Matsuyama.

Figura 31 (p. 76). Fotógrafo desconhecido. “Armazém de secos e molhados dos irmãos Ohara”. Mirandópolis, SP. 1934. 16 x 11 cm. Espólio da família Sakasegawa.

Figura 32 (p. 77). Fotógrafo desconhecido. "Fazenda São Joaquim”. No verso, lê-se, em português: "Tirada em 3-9-1943. Lembrança de Moriguchi. Na Fazenda São Joaquim (Ohara, irmão \& Cia.). Fila atrás (da direita): Izuka Moriguchi, Shinichi Otsuka, Kikuo Sato, Tatsuo Moriguchi, Moshiro Sakai, Noboru Aoki. Frente (da direita): Ichisaburo Kojima (sentado no colo: Kazuo Moriguchi), Eiji Sakasegawa, Torazo Fujita, Riorichi Moriguchi (no colo: Toshiko Moriguchi).” Mirandópolis, SP. 1943. Gelatina. 13, 5 x 9 cm. Espólio da família Sakasegawa.

Figura 33 (p. 78). Fotógrafo desconhecido. “Alberto Padovine e Hideo Matsuyama”. No verso, lê-se, em português: "Pescaria no Rio Paraguay, proximidade Porto de Manga, Hideo e Alberto Padovine”. Mato Grosso do Sul. 1953. Gelatina. 8, 5 x $6 \mathrm{~cm}$. Espólio da família Matsuyama.

Figura 34 (p. 79). Estúdio Kojima. "Hideo Matsuyama”. São Paulo. ca. 1960. Gelatina sobre cartão. 14 x $9 \mathrm{~cm}$. Espólio da família Matsuyama.

Figura 35 (p. 100). Fotógrafo desconhecido. "Soemon Sakasegawa”. Kagoshima, Japão. ca. 1900. Carte-de-visite, suporte gelatina. 15 x 9 cm. Obs. No verso, em português, lê-se: “O nosso querido vovô quanta saudade! - Saudade! - Faleceu com 74 anos de idade. Kowe Soemon Sakasegawa”. Espólio da família Sakasegawa. 
Figura 36 (p. 101). Fotógrafo desconhecido. "Ine Narita e amigas". Kagoshima, Japão. 1907. Carte-de-visite, suporte gelatina. 12 x $8 \mathrm{~cm}$. Espólio da família Sakasegawa.

Figura 37 (p. 102). Fotógrafo desconhecido. "Reprodução de retrato de Ine Narita, com dezesseis anos, em 1907”. São Paulo, SP. ca. 1950. Gelatina. 8, 5 x 5, 5 cm. Espólio das famílias Sakasegawa e Matsuyama.

Figura 38 (p. 103). Fotógrafo desconhecido. "Eiji, Ine e Akie Sakasegawa”. Iguape, SP. 1916. Gelatina. 12, 5 x 8 cm. Espólio das famílias Sakasegawa e Matsuyama.

Figura 39 (p. 104). Fotógrafo desconhecido. "Masato Narita e família”. Kagoshima, Japão. 1952. Gelatina. 13 x 8, 5. Espólio das famílias Sakasegawa e Matsuyama.

Figura 40 (p. 105). Estúdio Foto Ueno, Largo de Pinheiros. "Ine Narita Sakasegawa”. São Paulo, SP. ca. 1950. Gelatina. 13 x 9 cm. Espólio das famílias Sakasegawa e Matsuyama. Figura 41 (p. 128). Fotógrafo Severino Hisatsugui. "Neli, Akie e Satiko Matsuyama e Bruno Hisatsugui”. Campos do Jordão, SP. 1982/3. Gelatina. 12,5 x 9 cm. Coleção da família Matsuyama/Hisatsugui.

Figura 42 (p. 129). Fotógrafo Kikuo Nakamura. "Bruno, Luci e Akie Matsuyama”. Bariri, SP. 1983. Gelatina. 12,5 x $9 \mathrm{~cm}$. Coleção da família Matsuyama/Hisatsugui.

Figura 43 (p.130). Fotógrafa Neli Matsuyama. "Bruno e Akie - aniversário de 70 anos”. São Paulo, SP. 1984. Gelatina. 15 x 10 cm. Coleção da família Matsuyama/Hisatsugui.

Nota sobre as três últimas figuras: Procurei uma foto de mim com minha avó Akie, mas só encontrei de quando eu era criança. Talvez não tenha uma foto de mim mais velho com ela pelo fato de que, então, eu era o fotógrafo.

Figura 44 (p.131). Fotógrafo Makoto Shinmyozu. "Ichiko Matsuyama, Bruno, Hisako Matsuyama e Fuyoko Nagano Shinmyozu em frente à estação”. Kumamoto, Japão. 2011. Digital. Coleção do autor. 
Figura 45 (p. 132). Fotógrafo Makoto Shinmyozu. "Norio, Bruno e Fuyoko na casa da família Shinmyozu”. Kagoshima, Japão. 2011. Digital. Coleção do autor.

Figura 46 (p. 133). Fotógrafa Fuyoko Nagano Shinmyozu. "Makoto Shinmyozu e Bruno". Kagoshima, Japão. 2011. Digital. Coleção do autor. (uma coincidência, comprei minha camisa no Brasil, Makoto comprou a dele no Japão)

Figura 47 (p. 134). Fotógrafo desconhecido. "Fumi Matsuyama Nagano e gato". Kagoshima, Japão. ca. 1940. Gelatina. Dimensões desconhecidas (observação: a imagem foi enviada por Makoto Shinmyozu através de e-mail). Coleção da família Shinmyozu.

Figura 48 (p. 135). Fotógrafo desconhecido. "Shina Matsuyama“. Kagoshima, Japão. ca. 1940. Gelatina. Dimensões desconhecidas (observação: a imagem foi enviada por Makoto através de e-mail). Coleção da família Shinmyozu. 
Genealogias (na coluna esquerda, estão os pais, e, na direita, os filhos)

Família Sakasegawa - São Paulo

EIJI (Kagoshima 1892 - São Paulo 1952)

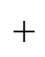

$+$

INE NARITA (Kagoshima 1891 - Arujá 1974)

AKIE (Iguape 1914 - São Paulo 2009)

HAMAKO (Iguape 1919 - Guarulhos 2004)

MATSUO (Santos 1924 - São Paulo 1982)

TOMIKO (Santos 1926 - São Paulo 1997)

MUNENORI (Santos 1929)

TOSHIO (Guararapes 1934)

Família Matsuyama - São Paulo

HIDEO (Kagoshima 1900 - São Paulo 1962)

$+$

AKIE SAKASEGAWA (Iguape 1914 - São Paulo 2009)

DEICY (Avanhandava 1933 - São Paulo 1971)

SATIKO (Avanhandava 1935)

MILTON (Avanhandava 1937)

LUCI (Avanhandava 1938)

NELI (Lins 1947)

LUIZ MASAO (Lins 1951) 
Família Matsuyama - Kagoshima

KOJIRO (Kagoshima 1857 - Kagoshima 1937)

KESA (Kagoshima 1864 - Kagoshima 1939)
MINE (Kagoshima $1880-?)$

SHINA (Kagoshima 1881 - Kagoshima 1947)

KUHI (Kagoshima 1882 - ?)

MASAO (Kagoshima 1890 - Kagoshima 1946)

FUMI (Kagoshima 1897 - Kagoshima 1979)

HIDEO (Kagoshima 1900 - São Paulo 1962)

SATSUO (Kagoshima 1903 - Kumamoto 1976)

HIROSHI (Kagoshima 1906 - Kagoshima 1935)

Família Nagano - Kagoshima

AKIYOSHI (Kagoshima 1894 - Kagoshima 1925)

FUMI MATSUYAMA (Kagoshima 1897 - Kagoshima 1979)
YOSHIFUSA (Kagoshima 1921 - Kagoshima 1945)

MUTSUKO (Kagoshima 1923 - Kagoshima 1997)

ISAO (Kagoshima 1925 - Kagoshima 1944)

FUYOKO (Kagoshima 1938) 


\section{Índice}

Lista de ilustrações

Genealogias

1. Fotos vernaculares e a multidisciplinaridade ............................................................. 1

2. Famílias de imigrantes japoneses em São Paulo (Metodologia).......................................... 12

3. Famílias Matsuyama e Sakasegawa ................................................................................ 24

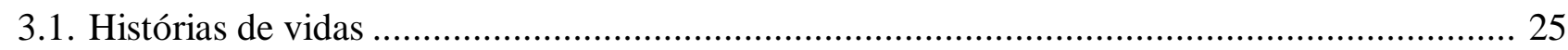

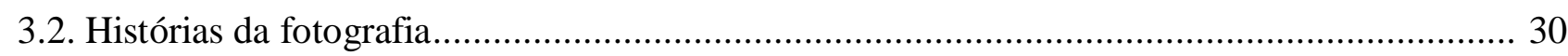

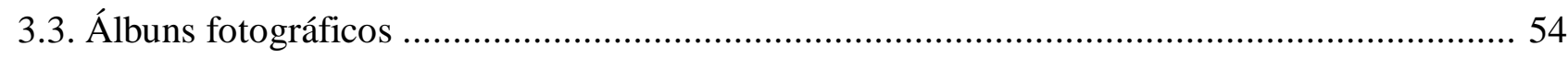

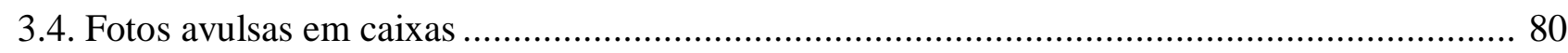

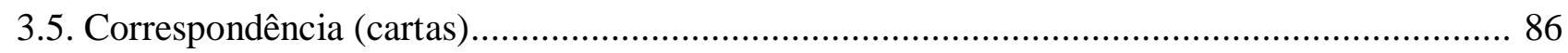

3.6. Repetição de fotos entre parentes .................................................................................. 95

3.7. As diversas encarnações de uma imagem (estudo de caso) ............................................... 105

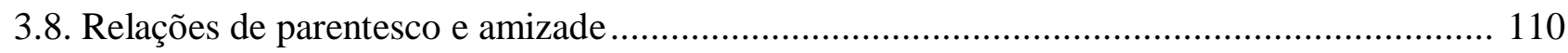

3.9. Construção e reconstrução de memórias ..................................................................... 111

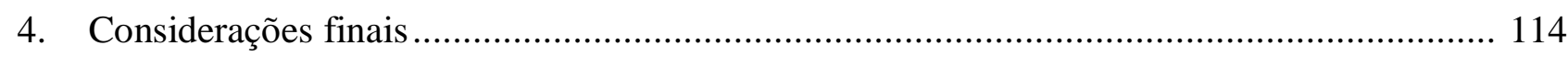

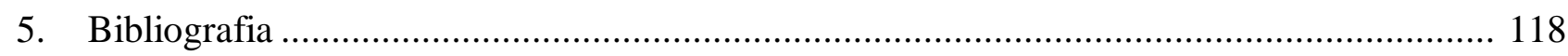




\section{Fotos vernaculares e a multidisciplinaridade}

Vernacular é um termo que tem sido utilizado em relação a fotografias, que escapa a definições rígidas. Por ser tão abrangente, incorpora outros termos anteriormente usados pela crítica como amador, popular, cotidiano, doméstico e nativo. John A. Kouwenhoven conjectura sobre as artes vernaculares e a política estadunidense:

Os produtos das artes vernaculares são ferramentas, brinquedos, prédios, livros, máquinas e outros artefatos cujas textura, forma, etc. foram uma resposta direta, sem instrução e inculta aos materiais, necessidades, atitudes e preocupações de uma sociedade que está se formando pelas forças gêmeas da democracia e da tecnologia. (KOUWENHOVEN, 1982, p. 23)

As fotografias feitas por pessoas comuns, com os propósitos mais diversos, também são consideradas artes vernaculares. Podem ser incluídos até mesmo os retratos realizados em estúdio por fotógrafos profissionais, quando destinados a usos apenas em âmbito privado e não público (identidade, passaporte, etc.). Como se nota, o que faz com que uma fotografia seja considerada vernacular pode diferir muito, caso a caso. Em geral, é de grande utilidade abordar os contextos de produção, circulação e consumo de cada fotografia. Em contextos diferentes da democracia (monarquias e colônias, os chamados primitivos, etc.), diferem também as estratégias e soluções de expansão da tecnologia fotográfica em cada local.

Pesquisadores de diversas áreas têm se dedicado às fotos de famílias. Richard Chalfen (1991) e Christopher Pinney (1997) se destacam em antropologia.

Chalfen trabalhou com duas famílias de imigrantes japoneses nos Estados-Unidos e suas coleções fotográficas. Ao interpretar os álbuns fotográficos, o autor procura mostrar como alguns costumes nipônicos se mantiveram na cultura dos imigrantes. Explora, ainda, questões de identidade, etnicidade, sentimento de pertencer a um grupo ("belongingness"), relações sociais, parentesco e unidade. 
Pinney realizou diversos estudos sobre fotografia na Índia, cobrindo desde a fotografia colonial, passando por estúdios fotográficos e alguns fotógrafos ambulantes remanescentes, até a foto publicitária. Sua pesquisa mostra como, para os indianos, não é o aspecto realista ou objetivo da fotografia que mais importa, mas sim sua capacidade de criar idílios por meio de artifícios diversos, desde figurino, objetos de cena e pano de fundo até as características fotografias pintadas à mão.

No caso da antropologia, é importante ressaltar a diferença de enunciação; ao contrário dos antropólogos que produziam imagens de populações estrangeiras para depois interpretar dados de cultura, isto é, uma visão de fora para dentro, a fotografia vernacular compreende objetos de cultura produzidos por seus próprios integrantes. Nesse sentido, aproxima-se do estudo de materiais culturais e pode oferecer uma visão reflexiva dessas culturas. "Reflexividade é uma tentativa de resistir às universalizações do conhecimento acadêmico e de insistir que esse conhecimento, como qualquer outro, é situacional e parcial.” (ROSE, 2007, p. 193-4)

Para o estudo da fotografia, esse viés é relevante por não ignorar as fotografias mais produzidas na história, fotos comuns feitas por pessoas comuns, "mediadas mais pelo afeto que pelo senso estético e artístico" (BATCHEN, 2001, p. 57). Devido às múltiplas formas que pode assumir, a fotografia vernacular nunca figurou, senão timidamente, nas grandes histórias da arte fotográfica. A dificuldade não está somente na multiplicidade de formas e discursos mas também na completa despretensão artística.

Por outro lado, as fotografias produzidas em esfera privada são capazes de despertar emoções profundas, lembranças esmaecidas, sensações latentes nas pessoas com quem têm relações. Elas contam um pouco da história das pessoas que se fazem retratar, tiram e colecionam fotos, montam álbuns e guardam uma determinada memória de si e de seres queridos. Longe de supérfluos, os modos pelos quais a aparência é gerida são complexos e 
específicos quanto a tempo e espaço. É como queremos ser reconhecidos, como optamos por

nos apresentar, como desejamos ser lembrados.

Esse material, aparentemente marginal, pode ser de interesse antropológico mesmo que não tenha sido concebido com intenções antropológicas. Ele contém aspectos importantes da experiência vivida que devem ser de interesse do antropólogo, e não ignorados. (EDWARDS, 1992, p. 13)

Assim, as fotos de família podem, além de iluminar aspectos da vida privada,

ampliar nossos conhecimentos sobre realidades históricas. Apesar dessas duas disciplinas,

fotografia e história, manterem relações nada estáveis ou simples, elas possuem similaridades.

Conquanto possam haver diferentes expectativas culturais sobre o que a historiografia e a fotografia podem revelar, ambas são restringidas pela natureza parcial da inscrição e compreensão históricas, a derradeira incognoscibilidade em termos holísticos, apesar da aparência de cognoscibilidade sobre a qual as esperanças fotográficas estão baseadas. (EDWARDS, 2001, p. 10)

Todas as linguagens, verbais e visuais, são fragmentos da realidade. Dessa forma, a história, a antropologia e a fotografia não podem abarcar senão interpretações limitadas de uma realidade observada ou vivida. E, ainda assim, são os fragmentos que nos permitem vislumbrar e compreender aspectos de vidas e mundos, passados e silentes. Apesar de fazer parte do passado, esses vislumbres ainda marcam o presente e, ao reinterpretá-los, é possível conferir a eles novos sopros de vida.

Todas as fotografias tem o potencial de representar a história de formas que talvez menos esperamos, quando não são simplesmente usadas como ferramentas evidenciárias, mas sim como instrumentos com os quais se pode refletir sobre a natureza da experiência histórica. As subjetividades localizadas, ao olhar para fotografias, deixam um espaço para articular outras histórias fora dos métodos históricos dominantes. Como sugeri, mesmo as fotografias mais conotativas, saturadas com as assimetrias das relações de poder e retóricas reificantes, podem desvelar momentos da experiência humana, pequenas narrativas que são constituídas ao mesmo passo que constituem as maiores. (EDWARDS, 2001, p. 236) 
Os diversos pesquisadores que se detêm sobre esse tema concordam que, além da imagem técnica propriamente dita, é também preciso atentar para os aspectos físicos da fotografia. Geoffrey Batchen usa o termo morfologia para ressaltar o volume, a opacidade, a tatilidade, enfim, a presença física da foto no mundo. Em Forget me not (2004), o autor expôe uma multiplicidade de objetos fotográficos vernaculares, quadros (de formatura, casamento, memento mori, etc.) onde a foto é apenas um dos elementos entre flores (reais ou de cera), inscrições e até pombas empalhadas, fotografias pintadas à mão, fotos onde os retratados exibem ou olham para outras fotos, bijuterias (broches, medalhões, brincos, pingentes, pulseiras, etc.) que combinam imagem fotográfica e cabelo, álbuns, caixas, colagens, travesseiros, abajures, etc. Essa diversidade mostra como a imagem fotográfica é pervasiva da vida cotidiana. Ao assumir funções de memória, a fotografia influencia e modifica processos cognitivos. O autor investiga, ainda, diferentes estratégias para se lembrar de entes queridos e, principalmente, para não ser esquecido.

Algumas formas fotográficas que tocam intimidades pessoais podem ser consideradas parentes das miniaturas (FRANK, 2000). Tanto as miniaturas pintadas quanto os retratos fotográficos (daguerreótipos, cartes-de-visite, etc.), por seu tamanho reduzido e tatilidade, induzem a fruições individuais em momentos privados de reminiscência.

Elizabeth Edwards, em chave semelhante, chama a atenção para a materialidade dos objetos fotográficos. Afinal, é esse aspecto material que faz com que a fotografia seja "ativa nas relações sociais" (EDWARDS, 2001, p. 13-16) e opere "rituais sociais e culturais" (BATCHEN, 2001, p. 77). Porém, segundo Pierre Bourdieu:

(...) a prática fotográfica não existe e não subsiste, na maior parte do tempo, senão por sua função familial ou melhor, pela função conferida pelo grupo familiar, a saber, de solenizar e eternizar os grandes momentos da vida familiar, enfim, de reforçar a integração do grupo familial, reafirmando o sentimento que ele tem de si mesmo e de sua unidade. (BOURDIEU et alli., 1965, p. 39) 
Seu famoso estudo sobre os usos sociais da fotografia, apesar de ser um marco teórico, deve ser lido com cautela, uma vez que seu campo de interpretação é restrito à França. Autores mais recentes, como Pinney, por exemplo, atentam para o fato que, além de reproduzir funções sociais, a fotografia também pode ser "criadora" (PINNEY and PETERSON, 2003, p. 11) de funções culturais, que observamos nas práticas heterogêneas de culturas que se apropriaram da fotografia longe das convenções em voga nas metrópoles.

Miriam Moreira Leite (2001) tende a concordar com Bourdieu em relação à representação de papéis sociais; as pessoas, nas fotografias, encenariam seus papéis sociais em detrimento de sua individualidade ou subjetividade. Assim, seria possível apenas identificar categorias recorrentes nas coleções fotográficas familiares: retrato individual, retrato de casal ou de casamento, retrato de recém-nascidos, bebês e crianças, retrato de batizado e primeira comunhão, retrato de pais e filhos, retrato de família ou grupo social (escolar, de esportes, teatral ou de música, etc.), fotografias de reuniões, jantares (ou à mesa), visitas, aniversários, festas, férias e viagens, lazer em geral. Essa sistematização é de alguma utilidade quando se trabalha com uma amostragem muito grande de fotografias. No entanto, é preciso compreender como essas categorias funcionam em cada recorte para estudo; em imigrantes japoneses, por exemplo, é comum encontrar fotos relacionadas ao trabalho, coisa rara ou inédita em álbuns fotográficos de europeus e estadunidenses. Outras categorias são igualmente variáveis segundo contexto e recorte populacional, tais como: animais (de trabalho ou domésticos), transporte (embarcação, caminhão, carro, motocicleta, etc.) e eventos sociais. Note-se que nenhuma dessas categorias é rígida e estática, podendo haver intersecções ou sobreposições entre elas. Porém, mais relevantes que as categorizações, são as relações que se dirigem: "do observador para a imagem, da imagem para o observador, de uma imagem para outra e dos retratados para o observador” (LEITE, 2001, p. 155). 
Assim, o observador ou o pesquisador tem e desenvolve relações sociais específicas em relação a seu objeto de estudo. Essa posição deve ficar clara, pois os agenciamentos que determinam o conhecimento influenciam os resultados. A visão reflexiva deve levar em conta o próprio pesquisador como uma voz parcial. As pesquisas inevitavelmente conterão erros, falhas e malogros, dentro de contextos específicos. Mesmo os acertos estarão localizados no tempo e espaço, dentre outras variáveis mais específicas. Assumir a imperfeição não desqualifica a busca em compreender. Daí, também, a multiplicidade de leituras que a linguagem fotográfica pode sustentar.

A autora ainda comenta sobre as diferenças entre as possibilidades expressivas da linguagem escrita e fotográfica. Cada qual possui suas particularidades e limites de expressão, tornando impossível a transcrição ou tradução integral de conteúdos fotográficos para conteúdos lingüísticos e vice-versa. Esse desencontro entre informação verbal e imagem, ainda segundo a mesma pesquisadora, enfatiza o fato de as fotografias serem pequenos recortes da realidade. Portanto, conclusões totalizantes são estranhas a esse tipo de objeto de estudo.

Por outro lado, as manifestações verbais podem adicionar informações às leituras das imagens fotográficas. São as legendas, anotações e comentários escritos no verso ou nas bordas das fotos ou nas páginas de álbuns de família. Tão ou mais idiossincráticas que as imagens, as legendas clareiam algumas entradas ao mesmo tempo em que obscurecem outras. Assim como nas memórias transmitidas oralmente, predominam as lacunas, o esquecimento paira e ameaça. Quando o pesquisador dispõe de profusos comentários escritos, sua interpretação estará mais privilegiada em relação aos contextos afetivos. Assim como, se dispuser de informantes que conviveram com as pessoas cujo espólio está a analisar, o resultado ficará menos elocubrativo e mais próximo das intenções dos criadores. No entanto, a falta de informantes não impossibilita a pesquisa. As fotos vernaculares, por serem tão 
comuns, tendem ao estereotípico; possuem alto grau de familiaridade e previsibilidade. Quando a recepção desse material íntimo se transfere da vida privada para usos públicos, mudam também as possibilidades interpretativas, em suma, a própria natureza desses objetos adquire outras características.

Martha Langford (2001), em sua pesquisa sobre a coleção de álbuns fotográficos, que datam entre 1860 e 1960, sob a guarda do museu McCord de história canadense, exemplifica bem as possibilidades interpretativas uma vez que o material deixou o lar da família para compor o arquivo de um museu. Com poucos registros escritos e sem descendentes para entrevistar, sua tese foca o álbum fotográfico em sua narrativa interna. Procura, desse modo, restaurar as funções comunicativas de cada álbum. Ao entrar nos acervos de um museu, o álbum fotográfico não se torna um objeto morto e petrificado, pelo contrário, adentra um processo dinâmico de ressignificações. Os múltiplos significados que possui se expandem em comparação com outros álbuns ou itens de uma mesma coleção.

A repetição está presente em qualquer tipo de linguagem, seja ela verbal ou imagética. Suas funções, no entanto, não são unívocas ou unilaterais. Na fotografia, pode assumir uma infinidade de sentidos, já que ela mesma é uma arte da repetição. A repetição de uma fotografia em coleções de diferentes parentes ou amigos pode ser uma reafirmação de laços de parentesco e amizade. Múltiplas cópias de uma foto de família podem ser feitas se essa imagem corresponder à imagem que o grupo tem de si. Essas imagens podem ser enviadas por correspondência para parentes e amigos distantes para reforçar a idéia de união. Uma mesma imagem pode aparecer mais de uma vez no mesmo álbum, o que pode ser uma consideração de carinho e afeto. Pode ser também decorrente do fato dessa pessoa não ter muitos retratos de si, portanto, uma mesma imagem tem de servir a fins diversos. Segundo Langford, a repetição é uma ferramenta narrativa que pode servir para melhor retenção de 
certas informações, por exemplo. A autora comenta como essa estratégia funciona no álbum fotográfico:

\begin{abstract}
A organização do álbum forma uma cadeia de repetições, visível em várias formas: temporal/situacional (a distribuição de fotos feitas numa mesma ocasião ao longo do álbum), emblemático (o tratamento de certos tipos de imagens como temas), formal (o estilo da página ou montagem) e factual (a múltipla apresentação de uma mesma imagem). (LANGFORD, 2001, p. 182)
\end{abstract}

Essa cadeia semântica dificilmente é linear ou inteiriça. São comuns fotos que interrompem a linha narrativa com dúvidas e digressões. A fragmentação é típica das linguagens e memórias. No caso da fotografia, isso é tão ou mais evidente, já que as fotos são fragmentos ou recortes da realidade. A própria organização dos álbuns, em geral, é caótica e irregular; raramente a ordem cronológica é respeitada. Mas é nessa aparente desordem que se podem vislumbrar traços latentes de intimidade e subjetividade. A difícil tarefa é compreender a lógica interna de cada álbum.

Tanto lembrar como esquecer fazem parte do funcionamento da memória. Não é possível lembrar-se de tudo, mas também não é possível esquecer-se de tudo. A seleção do que nos lembramos e do que nos esquecemos faz com que a memória não seja apenas um ato do passado, mas uma ação sobre o passado que possui influências sobre o presente e o futuro.

\begin{abstract}
A fotografia tanto detém o tempo quanto permite que aquele passado congelado seja invocado novamente, seja feito presente. Está, então, intimamente relacionada a sentimentos de memória, nostalgia e arrependimento, à presença de uma ausência. (...) Aqui, então, a memória tende à suspensão de movimento e mudança. (...) Essa atividade de tornar o passado presente, de estar acima do fluxo e mudança, que são parte do tempo histórico e cronológico, está vinculada ao papel da memória de guardiã no centro da identidade. (BOOTH, 2006, p. 24)
\end{abstract}

Nem a memória nem a identidade são estáticas, ambas estão sujeitas a reelaborações ao longo do tempo, estejam elas associadas a um indivíduo ou a um grupo. Assim, o esquecimento também não é fixo; podemos não nos lembrar de algo num dado momento, mas 
recuperar aquela impressão em outro; podemos também nos esquecer de algo que um dia já foi importante e claro. Os esquecimentos "são parte de nossa identidade, como uma presença da ausência ou como a reação da lembrança àquela ausência.” (BOOTH, 2006, p. 82)

Martin A. Conway e David C. Rubin também acreditam que a memória não é rígida ou congelada e defendem que "as memórias são compilações, construções ou composições de conhecimento" (CONWAY and RUBIN, in: COLLINS, GATHERCOLE, CONWAY, MORRIS, 1993, p. 104). Dessa forma,

\begin{abstract}
(...) a natureza composicional do conhecimento autobiográfico facilita a construção de memórias nas quais conhecimentos "esquecidos" podem ser novamente recordados, novas interpretações podem ser dadas a memórias estabelecidas, e o tipo de conhecimento que foi recuperado pode ser ajustado às necessidades de uma tarefa particular (como em recordações). Assim, a vista estrutural da memória autobiográfica pode acomodar tanto estabilidade quanto flexibilidade ao se recuperar memórias. (CONWAY and RUBIN, In: COLLINS, GATHERCOLE, CONWAY, MORRIS, 1993, p. 109)
\end{abstract}

Um outro ponto, já mencionado, de concordância entre diferentes disciplinas, cujos limites estão menos demarcados, em benefício das pesquisas (Annateresa Fabris (1998) em Artes Visuais, Leite em História, Chalfen, Edwards, Pinney e Rose em Antropologia, Batchen e Frizot em Fotografia, dentre outros), é a necessidade de abordar os contextos de produção, as histórias da circulação e os motivos de consumo de cada material fotográfico, para discutir questões culturais acerca da representação fotográfica. Impossível e desnecessário criar uma metodologia única ou seminal; será melhor pensar em campos que se expandem e entrelaçam. Por conta da heterogeneidade da fotografia vernacular, são necessários múltiplos modos interpretativos.

Fotos de família são estilos particulares de imagens inseridas em práticas específicas, e é a especificidade dessas práticas que define uma fotografia como uma foto de família tanto, senão mais, do que o que ela retrata. O que é importante em uma fotografia de família: quem a tirou; quem ela mostra; onde e como ela foi mantida; quem fez cópias dela, e as enviou para outras pessoas; quem são essas 
outras pessoas; e a maneira como ela é vista por todas essas pessoas. (ROSE, 2010, p. 14)

Uma vez que a linguagem fotográfica possui ampla "margem de indeterminação" (SIMONDON, 1969, p. 134-147), cada objeto fotográfico possui, por sua vez, alto grau de especificidade. Devido a essa indeterminação do meio fotográfico, diferentes objetos fotográficos exigem diferentes enfoques metodológicos.

Os desafios de interpretar ou compreender os diferentes objetos fotográficos estão num certo respeito e paciência para encontrar possibilidades discursivas a partir deles mesmos, e não impor um discurso exterior.

Mais do que cristalizar verdades absolutas, o conhecimento científico deve levantar questões, dúvidas, incertezas (inclusive a respeito de si mesmo). Uma série de perguntas bem formuladas pode valer mais do que algumas certezas provisórias:

Com qual propósito a imagem fotográfica foi feita? Quem a guardou? A foto é um resultado da visão do fotógrafo ou da imagem que o sujeito tinha de si? Qual foi a relação entre fotógrafo e objeto? O que o retratado pensava da fotografia? Os retratados também praticavam fotografia, em caso afirmativo, eles possuíam uma visão nativa única? Como a população local utiliza a fotografia? Quais tipos de informação essas fotografias contêm e qual sua relevância para o pesquisador? As fotografias refletem mudanças culturais ou representam um tempo histórico estático? Quem colecionou, exibiu e/ou escreveu sobre essas fotografias? (SCHERER, 1992, p. 36)

Para finalizar este trecho, um breve comentário sobre o texto clássico sobre a fotografia de Roland Barthes, A câmara clara. O que mais chama a atenção neste livro são as reflexões sobre as muitas camadas de tempo contidas em qualquer foto e sobre a morte, na busca do autor por uma fotografia de sua mãe recém-falecida na qual ele pudesse reconhecêla, "uma imagem justa, uma imagem que fosse a um só tempo justiça e justeza" (BARTHES, 1984, p. 103): o retrato de sua mãe e seu tio, quando crianças, no jardim de inverno, que ele descreve, mas não mostra. Barthes ecoa o desejo de outro autor, Paul Valéry, na ocasião da 
morte de sua mãe, "escrever uma pequena série de textos sobre ela, apenas para mim" (BARTHES, 1984, p. 95/6), assim, há essa mesma tensão pairando sobre a foto, que ele sabe ser importante apenas para ele. Desse modo, ele indica que a relação entre um sujeito e uma fotografia é particular e idiossincrática, impossível de ser universal e unívoca. Em um volume de ensaios sobre esse texto clássico, Photography degree zero (2009), todos os autores comentam de algum modo a relação de Barthes com a foto de sua mãe, que é o eixo da narrativa. Mais do que simplesmente uma série de escritos sobre a fotografia, o livro de Barthes é sobre o afeto e o amor. Afinal, “(...) falar de fotografia é sempre falar de amor.” (CADAVA and CORTÉS-ROCCA, 2009, p. 113). 


\section{Famílias de imigrantes japoneses em São Paulo (Metodologia)}

Antes de iniciar o mestrado, consultei três acervos iconográficos, o do Museu Paulista, o do Memorial do Imigrante e o do Museu Histórico da Imigração Japonesa no Brasil. O primeiro é uma passagem essencial para qualquer interessado na fotografia de São Paulo, em especial, a coleção de Militão Augusto de Azevedo, objeto de um estudo recente de Íris Morais Araújo (2010). Devido a seu volume, durante pouco mais de um mês, foram cerca de trinta horas de consulta. Nos outros dois, pesquisei cerca de quinze horas, em cada. Minha intenção inicial era tentar compreender, através de imagens fotográficas, a passagem da escravidão negra para os processos migratórios voluntários.

Se, por um lado, as imagens da escravidão negra já estavam sendo objeto de diversos estudos (para citar apenas alguns: African American Vernacular Photography, 2005; ALLEN, ALS, LEWIS, LITWACK, 2008; ERMAKOFF, 2004; KOSSOY \& CARNEIRO, 2002; KOUTSOUKOS, 2010; WILLIS, 2000), a imigração japonesa ainda tinha muito campo para investigação, principalmente no que se refere à iconografia fotográfica.

Dessa forma, havia pouco material fotográfico de imigrantes japoneses nos acervos públicos, especificamente, as fotos de família. Evidente que material tão particular ainda está nas mãos dos descendentes.

Ao trabalhar com fotografia vernacular, um grande desafio é o levantamento de material. Por se tratar de produção privada, essas fotografias se encontram em posse dos descendentes que, de diferentes modos, conservam seus álbuns de família. Desse modo, as fotografias ficam à mercê de fungos, mofos e intempéries diversas. Importante lembrar que o processo de decomposição é contínuo e se tratam de fotos com pelo menos sessenta anos de idade, tempo mais que suficiente para causar danos sérios, caso não recebam cuidados, 
segundo a especialista em conservação de acervos fotográficos do Centro de Memória da Unicamp, Marli Marcondes.

Como eu mesmo descendo de imigrantes japoneses, senti que pela minha aparência e posição social poderia levantar esse material fotográfico privado para fins acadêmicos, evitando, assim, que ele se perdesse no esquecimento.

O primeiro problema foi a maneira como abordá-los.

Quais poderiam formar um grupo dito representativo?

No começo, não sabia bem o que eu poderia fazer com as fotos deles.

Não gostaria de impor qualquer tipo de contato violento ou opressivo.

A princípio, tateando delicadamente, comecei por minha própria família; meus avós maternos: Matsuyama, Sakasegawa, meus avós paternos: Hisatsugui, Hirata, e, aos poucos, fui ampliando esse círculo através da família estendida, Umeki, Uehara, Tomita, Okazaki.

Uma vez que havia começado, também pude observar, ainda que apenas superficialmente, alguns álbuns fotográficos da família de um amigo, Shirakawa.

Uma família desconhecida, Hara, se voluntariou a emprestar suas fotografias, quando a pessoa que guarda esse material (a neta dos imigrantes) tomou conhecimento de minha pesquisa através de uma conversa trivial, numa fila de banco.

Nesse momento inicial, era importante trabalhar com o material de famílias que demonstrassem boa vontade e disponibilidade para entrevistas subsequentes, além de ter uma abertura para trilhar um longo caminho, que eu mesmo ainda não sabia qual seria o desfecho. Confiança e respeito foram palavras-chave desde o começo.

No momento de entrega do material fotográfico, era costume realizar uma breve entrevista não estruturada. Os objetivos eram averiguar a proximidade da pessoa que atualmente guarda o material com a pessoa que produziu ou coletou o mesmo material e investigar as memórias associadas àquelas fotografias. Outro objetivo era fiar uma reduzida 
história de vida dos imigrantes de cada família, atentando para as dificuldades comuns e certas particularidades.

Infelizmente, as informações que puderam ser levantadas através dos descendentes eram superficiais e rarefeitas. Isso porque a maioria dos descendentes que guardavam os materiais fotográficos eram filhos caçulas ou netos dos imigrantes.

Em suma, o que resultou desse primeiro instante foi um grande volume de material fotográfico, mas poucas informações e memórias relacionadas a ele.

De todo modo, fiz uma primeira reprodução digital de todo o material, de forma rudimentar, mas que permitiu um manuseio mais fácil e ágil. Isso também possibilitou devolver às famílias cópias digitais de seus álbuns e fotografias, que é uma nova estratégia para conservar esse material.

O que pareceu significativo, então, além da organização das fotos em álbuns, foi a repetição de determinadas imagens e determinados temas.

Uma sugestão oferecida por meu orientador serviu para dar um rumo mais objetivo à pesquisa. Seria melhor escolher apenas uma família para essa pesquisa pontual, de preferência a minha família. A princípio, confesso que tive receios sobre essa direção, pois o risco de cair em egolatrias parecia incontornável. Mas a possibilidade de falar sobre questões, senão universais, pelo menos comuns, a partir do particular, acabou por me convencer. Assim, o grande tema de minha jornada continuaria a ser a identidade. Neste caso, a minha e a de outros em condição similar.

Como já tinha uma certa ideia sobre as histórias de vidas dos imigrantes das famílias que me emprestaram os materiais fotográficos, os percursos dos imigrantes da família de minha mãe pareceram mais problemáticos, portanto, mais aptos a serem trabalhados, uma vez que chegaram mais cedo do que os outros (1912 em comparação ao ápice migratório na década de 1930). Outro fator que pesou nessa escolha foi o fato de meu avô, Hideo 
Matsuyama, ter vindo ao Brasil em tenra idade (doze anos) na mesma embarcação que seus futuros sogros, o casal Sakasegawa.

Uma vez delimitada a família para pesquisa, estabeleci como centrais os dois casais: Hideo e Akie Matsuyama, Eiji e Ine Sakasegawa. Meus possíveis informantes eram, então, Toshio e Munenori Sakasegawa (filhos caçulas de Eiji e Ine), Satiko e Luci Matsuyama (as filhas mais velhas de Hideo e Akie), Kiwa Makinodam Irino (filha da irmã de Ine, também imigrante; e prima de Akie), Honório e Sérgio Sakasegawa (netos de Eiji e Ine).

Já tinha em mãos o espólio (álbuns, fotos e cartas) de Hideo e Akie e uma caixa de fotografias de Eiji e Ine. Esse material se tornou a base e o centro da pesquisa. As fotos das outras famílias serviram para compor um termo de comparação.

Conduzi entrevistas não estruturadas, com fotografias, com todos os informantes (Toshio, Munenori, Satiko, Luci, Kiwa, Honório e Sérgio). Por diversas razões, realizei repetidos encontros com Satiko e Toshio, alguns, gravados em vídeo. Esses dois informantes se tornaram centrais para a pesquisa, Satiko, por ter sempre vivido com a mãe e por ter guardado as fotos e cartas, e Toshio, pela prolixidade e disposição.

A escolha de sujeitos pela possibilidade de múltiplas entrevistas também foi chave na composição das famílias cujas fotografias serviram de base para este estudo. Através de muitos encontros, foi possível formar um elo de confiança, o que melhorou a disposição em elaborar as memórias e, assim, aprofundou o conteúdo das entrevistas (WELLER, 1998).

A metodologia de pesquisa para o uso de fotografias etnográficas em investigações antropológicas inclui: (1) análise detalhada de evidências internas e comparações de fotografias com outras imagens; (2) entendimento da história da fotografia, incluindo convenções e limitações tecnológicas; (3) estudo de intenção e propósito do fotógrafo e a maneira como as imagens foram utilizadas por seu criador; (4) estudo dos sujeitos etnográficos; e (5) bibliografia histórica correspondente. (SCHERER, 1992, p. 34) 
Minha hipótese inicial era que, através dos retratos fotográficos, eu poderia investigar a identidade dos imigrantes japoneses, que me parecia múltipla, nem japonesa, nem brasileira. O que sustentava essa hipótese era a estreita ligação entre o retrato fotográfico e a individualidade moderna (ARIÈS, 1973, p. 230; SEKULA, 1989; TAGG, 1988). Isso significava que certos aspectos identitários poderiam ser questionados através da história familiar organizada em álbuns de fotos. As reflexões em relação à certa elasticidade na identidade dos imigrantes japoneses foram apoiadas e ampliadas principalmente pela seleção de ensaios editada por Nancy R. Rosenberger (1992) e pelo abrangente estudo realizado por Jeffrey Lesser (2001).

Uma segunda hipótese, deduzida a partir de parte da bibliografia, era que as relações de parentesco foram mantidas através de cartas e fotos. Segundo John W. Connor, "para praticamente nenhum imigrante (issei) a viagem à América representou uma ruptura completa e final com sua família no Japão.” (1977, p. 88). Eram dignas de exame, portanto, as maneiras através das quais essas relações foram mantidas, conquanto transformadas.

As hipóteses iniciais eram suficientemente amplas para que no trabalho de campo elas pudessem ser modificadas e, não obstante, outras hipóteses pudessem surgir.

Isso estava de acordo com a metodologia reflexiva debatida em antropologia visual. Charlotte Aull Davies afirma que essa abertura é uma prerrogativa necessária a qualquer aprendizado. Afinal, se o trabalho de campo servisse apenas para corroborar as hipóteses e premissas elaboradas em laboratório, ele seria desnecessário, ou, no mínimo, incapaz de reconhecer a complexidade das realidades observadas. Para essa pesquisadora, a reflexividade é o "meio através do qual o conhecimento de uma realidade social pode ser abordado" (2008, p. 265). Ela aponta como características da reflexividade formas dialógicas e polivocalidade, e sugere que uma postura de flexibilidade é essencial. 
Outras autoras, como Gillian Rose (2007) e Sarah Pink (2001), também identificam o conhecimento acadêmico como parcial e localizado, crivado de escolhas. Devido a esse alto grau de seletividade, as autoras sugerem que o texto deve tornar esse processo transparente.

Do mesmo modo, Jon Prosser insiste que a pesquisa deve carregar uma lógica colaborativa, dialética e interativa, e sumariza: "Relatos reflexivos tentam deixar explícito o processo pelo qual informações e conclusões foram produzidas.” (2003, p. 104)

Frederick Steier, em conclusão, afirma que a pesquisa deve ser um "processo recíproco" (1991, p. 7), ou seja, as estruturas e lógicas de pesquisa devem ser passíveis de análise, e não imutáveis.

A dificuldade em conciliar e interpretar as diferentes vozes dos informantes para compreender as experiências dos imigrantes é um dos maiores desafios do texto. A tentativa de adensar as vidas íntimas dos imigrantes peca principalmente por não ter tido contatos diretos, isto é, as experiências dos imigrantes foram deduzidas através de relatos de filhos e netos e de rastros deixados em cartas e fotografias. Um estudo útil sobre biografias, relatos e histórias de vidas, foi feito por Langness e Frank, Lives (1981). Esse volume aponta como uma das peças-chave para qualquer metodologia antropológica a necessidade de estar aberto para ouvir os sujeitos sem preconceitos. Outro interessante estudo sobre metodologias e questões relacionadas a aspectos culturais de histórias de vidas foi realizado por John L. Caughey (2006). Sua abordagem pessoal e reflexiva serviu para indicar caminhos de investigação.

Planejado para resultar em uma biografia cultural dupla (de duas pessoas), o método proposto aqui requer que você, o pesquisador, conduza uma investigação cultural sobre outra pessoa e, simultaneamente, uma investigação cultural sobre si mesmo. (CAUGHEY, 2006, p. xi) 
O intercâmbio de pesquisadores mantido pelo Centro de Estudos Japoneses (CEJAP) da Universidade de São Paulo e o Research Center for Non-written Cultural Materials, Institute for the Study of the Japanese Folk Culture, da Universidade de Kanagawa, em Yokohama, possibilitou-me ficar nesse último por três semanas, em outubro de 2011.

Nesse período, fui orientado pelo professor Hidekazu Sensui, doutor em antropologia. Ele foi muito atencioso e prestativo. Fiquei muito agradecido por tudo o que ele fez por mim. Nossas conversas foram de extremo auxílio para mim, e, além disso, muito prazerosas.

Visitamos dois acervos públicos, onde pude constatar que a importância da fotografia para as famílias de imigrantes estava longe de ser restrita ao Brasil.

O primeiro acervo foi o do Museu da Migração Japonesa ao Exterior, Japan International Cooperation Agency (JICA), em Yokohama. Lá, fomos muito bem recebidos pela senhorita Elena Yamagata.

O outro acervo foi o da Fundação Nippon Rikkokai, onde conhecemos o senhor Naoki Tanaka, que foi extremamente atencioso e solícito.

Nesses dois acervos, pude ver diversas fotos de famílias de imigrantes japoneses de diferentes países (Argentina, Bolívia, Bornéu, Brasil, Chile, Cuba, Estados-Unidos, Paraguai, Peru).

Assim, comecei a compreender que a minha pesquisa, apesar de muito particular, poderia realmente falar de questões universais aos imigrantes japoneses em geral. Afinal, todos eles utilizaram a fotografia de modo muito similar, resguardadas as particularidades locais.

Além da biblioteca central da Universidade de Kanagawa, consultei a biblioteca do Institute for the Study of Japanese Folk Culture e a biblioteca do Tokyo Metropolitan 
Museum of Photography. Pela riqueza desses acervos, pude expandir a bibliografia consultada.

O professor doutor Sensui apresentou-me à senhorita Miho Nagai, atual curadora do Shibusawa Memorial Museum, que já havia trabalhado no Museu Histórico da Imigração Japonesa no Brasil, em São Paulo. Essa pesquisadora organizou, em 2008, uma exposição sobre a colônia de Iguape, onde a família Sakasegawa morou. Ficamos espantados e felizes com a coincidência. Ela, então, levou-me à National Diet Library, em Tóquio, que possui diversos documentos sobre essa colônia. Pacientemente, ela traduziu o conteúdo geral dos documentos para que eu pudesse selecionar aqueles que seriam de interesse para minha pesquisa. Sou muito grato por sua atenção e cuidado.

$\mathrm{Na}$ Universidade de Kanagawa, ainda conheci o doutor em antropologia, Kouichiro Kobayashi, que, juntamente com a senhorita Nagai e o professor doutor Sensui, colaboraram com minha metodologia para trabalho de campo em Kagoshima.

Ao chegar em Kagoshima, à princípio, fui para um hotel. Como não sabia direito o que esperar, tratei de agir cautelosamente. A prima de minha mãe, Fuyoko, através de e-mails, já havia me convidado para ficar na casa da família. No entanto, não quis, logo de saída, invadir a privacidade alheia.

Na manhã seguinte, encontrei com Fuyoko e seu filho mais velho, Makoto. Eles novamente insistiram muito para que eu ficasse na casa da família, então, agora cara a cara, sentindo sua hospitalidade e generosidade, aceitei ficar com eles durante a semana que passei em Kagoshima. Apesar de nunca termos nos encontrado antes, eles me trataram como parte da família, sem desconfianças. Antes disso, tínhamos apenas trocado cartas e e-mails. Como eles me receberam de coração aberto, eu realmente me senti bem-vindo nessa casa, estranha porque nova para a percepção, mas familiar. 
Nesse curto período, eles me levaram para conhecer a província de Kaseda. Lá, visitamos o santuário da família Sakasegawa e o lugar onde era a casa da família Matsuyama, onde meu avô nasceu e cresceu. A casa das famílias não existe mais, mas fomos aos terrenos onde um dia elas ocuparam. Aparentemente, não havia nada de especial no local onde era a residência da família Matsuyama. A vegetação cobriu todos os vestígios. No entanto, é indescritível o sentimento que me possuiu quando estava lá. Havia apenas árvores e mato, mas eram árvores e matos muito específicos e especiais simplesmente por estarem naquele local. Na mesma área, há um riacho que Fumi cita em uma das cartas a Hideo, o riacho da infância onde eles brincavam. Coisas simples, mas talvez sejam elas as que tocam os sentimentos mais profundos.

Visitamos também o cemitério em Kagoshima, onde ficam os túmulos das famílias Matsuyama e Nagano.

Apesar de não seguir nenhuma religião, participei da limpeza dos locais e acendi incensos em agradecimento aos antepassados, com sinceridade. Não creio ser necessário se filiar a religiões para se cultivar a espiritualidade. Assim, quando fazíamos as refeições no lar da família Shinmyozu, eu sempre pedia para levar a primeira colherada de arroz branco como oferenda para os ancestrais no butsudan (altar familiar dedicado aos deuses e aos antepassados segundo a crença budista). Nessas ocasiões, eu agradecia com uma reverência, sentado em seiza (maneira formal e tradicional japonesa de se sentar), pela oportunidade de estar na casa dos descendentes de Fumi, em Kagoshima.

Fomos ainda a Kumamoto conhecer Ichiko e Hisako, duas outras primas de minha mãe, filhas de Satsuo, irmão de Hideo. Ao chegar, fomos visitar um ponto turístico, o castelo de Kumamoto. Depois, fomos almoçar num restaurante. Ao longo dessa refeição, conversamos sobre a família. Fuyoko levou fotos antigas enviadas por Hideo para sua mãe, fotos recentes da família Matsuyama que minha mãe enviou, e fotos recebidas do Japão por 
Hideo da família Matsuyama que eu havia enviado há pouco. Ela levou também um esquema genealógico. As ramificações da família (de qualquer família, na verdade) são tão complexas que é difícil visualizá-las sem a ajuda desses diagramas genealógicos e de fotografias. Uma das fotos do espólio de meu avô, que eu havia enviado para Fuyoko, era um retrato de Ichiko, quando jovem (Figura 27). Como essa é uma de minhas fotos preferidas, esse encontro foi especialmente tocante para mim, pois pude conhecer a mulher do retrato, mais ou menos cinquenta anos após ele ter sido feito. Tive uma sensação de estranheza pelos muitos tempos presentes nesse dia, um retrato de cinquenta anos atrás, minhas lembranças de contemplar esse retrato de uma mulher que não conhecia, e encontrar a mulher do retrato como uma senhora de setenta anos. Eu e ela ficamos nos admirando, querendo fixar a impressão de beleza do outro em novas fotografias pois a memória não seria o bastante. Ficamos absortos nesse encontro, enamorados um com o outro. As duas primas de minha mãe ficaram muito felizes em me conhecer, em conhecer uma parte da família no Brasil. Depois do almoço, elas fizeram questão de comprar um presente para mim. Escolhi uma camisa de flanela, e elas pediram para que eu me lembrasse delas quando vestisse essa camisa no momento em que eu pensava que sempre me lembraria delas e desse dia quando vestisse essa camisa. Pequenos gestos e pequenos agrados que fazem o coração transbordar. Nos despedimos profundamente agradecidos pela chance de nos conhecermos.

Depois de dias cheios de emoção, à noite, Fuyoko sempre servia um jantar especial, com iguarias locais (como exemplos: porco negro, mexericas pequeninas e shôch $\hat{u}$, bebida alcoólica destilada de batata-doce) e outras comidas típicas japonesas, mas com particularidades locais (destaque para o arroz branco feito em panela tradicional, não elétrica). Então, ficávamos conversando sobre as famílias até tarde.

Fuyoko mostrou-me as fotos que sua mãe, Fumi, recebeu de meu avô, Hideo. Também havia três cartas enviadas para Fumi pela família Matsuyama do Brasil. 
Por intermédio da senhorita Miho Nagai, conheci o professor doutor Yuji Kurose, da Universidade Internacional de Kagoshima. Ele havia feito algumas pesquisas sobre a colônia de Iguape, então, ficou interessado nas informações que levantei sobre a família Sakasegawa. Tivemos uma agradável conversa em Kagoshima. Pudemos comparar dados e constatar algumas disparidades em nomes e datas. E falamos sobre o processo de emigração em Kagoshima.

Foi curto o período que passei na casa de minha família no Japão, mas creio que foi de grande importância para ambas as partes. Após quase cem anos, nosso encontro foi o reencontro simbólico de nossos antepassados. De minha parte, meu avô, Hideo, da parte deles, a mãe e a avó, Fumi, que se separaram quando crianças e nunca mais se reviram.

Quando fui embora de Kagoshima, Fuyoko escreveu um e-mail para minha mãe. Não é a intenção vangloriar-me de qualidades que ela atribui a mim nessa mensagem, apenas mostrar o sentimento com que fui tratado.

\footnotetext{
Neli-san deve ter ficado preocupada com o Bruno. Ele partiu para Ibaraki e por isso ficamos tristes. Ele é um ótimo rapaz e eu gostei muito dele! Tratei-o como a um filho. Gostaria de ter feito mais coisas por ele, mas, pelo curto tempo de sua permanência, não foi possível. Depois que o meu marido Norio ficou doente, não pôde mais dirigir e, por isso, não conseguimos atendê-lo melhor. Ele saboreava de tudo dizendo oishii (delícia) e isso me deixou muito feliz. Neli-san tem um filho de quem pode se orgulhar! O sorriso de Bruno encantou a todos que encontrávamos. Meu filho Makoto, que o acompanhou aos lugares, se deu bem com ele. Seu filho Bruno se portou melhor que nós japoneses. Ficamos muito admirados com isso! Se pudesse, gostaríamos que ele permanecesse por mais tempo em Kagoshima. O local onde ele está faz frio e estou preocupada se não vai se resfriar. A propósito, o agradecimento ficou tardio, mas agradecemos os presentes que ganhamos e que foram feitos com tanto carinho. Estamos muito agradecidos. Usaremos com muito carinho e cuidado. Por favor, mande lembranças a todos.
}

Assim, é possível sentir que os laços familiares foram restabelecidos. Apesar dos encontros serem raros, e, portanto, profundamente preciosos, a troca de cartas, fotos e pequenos presentes se intensificou. Desde então, essa troca ocorre através dos correios e da 
internet. Se antes de nosso encontro já havia muito carinho nas trocas interpessoais, agora, há amor e saudades.

Antes de deixar o Japão, ainda reencontrei Fuyoko e Makoto em Tóquio. Makoto vive e trabalha em Tóquio, Fuyoko estava na cidade para ver seus netos que moram em Kanagawa, por ocasião do natal, mas também para se despedir de mim. Eles me levaram a pontos turísticos e tivemos a chance de conversar mais um pouco sobre a história da família. Fuyoko quis me levar para comer em lugares que serviam coisas que ela já sabia que eu gosto, muitas dessas coisas existem no Brasil, mas são realmente diferentes (tempura, tofu, nabo finamente ralado com ovas de peixe, sashimi de peixes da estação e de polvo, meu preferido). Na manhã de minha partida, Fuyoko me encontrou no ponto de ônibus. Foram os últimos momentos que passamos juntos, nos primeiros ventos do inverno. Ela me entregou um presente de natal para minha mãe. E ficamos esperando pelo ônibus para o aeroporto internacional de Narita. Despedimo-nos com muita emoção, profundamente agradecidos pela oportunidade de termos nos conhecido. Fuyoko ficou no ponto oeste da estação de Shinjuku até que o ônibus sumiu de vista. Isso me fez lembrar minha avó Akie, que sempre se despedia das visitas desse modo. Uma gratidão intransitiva, gratidão pela oportunidade e experiência vivida.

Esse é um trabalho sobre separações incontornáveis e reencontros simbólicos, amores e saudades, temperado pela sinceridade do suor e das lágrimas de muitas gerações. 


\section{Famílias Matsuyama e Sakasegawa}

A pesquisa que realizei se concentrou em minha avó materna Akie Sakasegawa Matsuyama e suas famílias: seus pais e irmãos (Sakasegawa) e seu marido e filhos (Matsuyama). Não conheci meu avô Hideo Matsuyama. Talvez este estudo seja a maneira que encontrei de conhecer um pouco de sua história. Convivi, por alguns anos, com minha avó, Akie, nas mesmas casas. Por infortúnio, ela faleceu pouco antes da pesquisa começar. Estranho que, apenas então, vi os álbuns de família com fotos antigas.

As fotografias e os álbuns eram objetos de grande valor nostálgico para minha avó, reservados para momentos íntimos, de acordo com sua segunda filha mais velha, Satiko, com quem morou por muitos anos. Provavelmente, ela teria me mostrado, caso eu tivesse pedido, mas confesso que a ideia nunca me ocorreu. Em parte, porque eu nem imaginava que eles existiam. Pensando melhor, acho que nunca fiz uma única pergunta sobre meu avô, talvez por achar que lembrar o marido a faria sofrer.

Os dois álbuns fotográficos são parte das coleções que consultei para escrever. Foram montados por Satiko e legendados parcialmente por Hideo. Há ainda muitas fotos avulsas, guardadas em caixas, junto a cartas diversas. A associação desses dois tipos de materiais, fotografias e cartas, também foi constatada por outros pesquisadores, como Richard Chalfen (1987; 1991), Françoise Noël (2003), Irene Nogueira de Rezende (2004), Gillian Rose (2010) e Wendy Cameron, Sheila Haines e Mary McDougall Maude (2000).

Na recolha de material fotográfico, a esposa de um sobrinho (Honório, filho de Matsuo) de Akie cedeu-me uma caixa de fotos da mãe de Akie, Ine. Algumas fotos foram encontradas com os irmãos de Akie, Munenori e Toshio, e com sua prima, Kiwa. Outras foram encontradas com a sobrinha do casal Matsuyama, Fuyoko, filha de Fumi, em 
Kagoshima. As relações de troca puderam, então, ser constatadas na repetição de certas imagens em coleções ou casas diversas.

Observação: os nomes japoneses foram corrigidos para sua forma original em função da coesão textual. As adaptações e erros sofridos em cartórios foram ignorados uma vez que não eram pertinentes à pesquisa.

De todo modo, os nomes são parte das identidades. Uma vez que se modifica o nome pelo qual atendemos e somos reconhecidos, também muda nossa visão de nós mesmos.

\subsection{Histórias de vidas}

O espólio de fotografias e cartas é resultado de seleção e acúmulo de material através dos anos. É preciso recontar os relatos sobre a vida de meus avós. O texto a seguir tem como base, principalmente, os relatos de Satiko, em relação à família Matsuyama, e de Toshio, em relação à Sakasegawa. Foram também empregados documentos oficiais brasileiros (visto de imigração, controle de imigrantes, atestado de óbito) e japoneses (relatórios da administração da colônia de Iguape, Katsura).

Mais do que um retrato exato, perfeito e rigoroso da vida de meus avós e bisavós, este texto revelou-se uma reinterpretação dessas vidas, um esforço colaborativo entre duas gerações (nissei e sansei) de descendentes de imigrantes japoneses. "Cada nova geração traz novas perspectivas, novos entendimentos e novos esquecimentos.” (HOLLAND, 1991, p. 1)

Hideo Matsuyama nasceu em trinta de março de 1900, na província de Kaseda, na cidade de Kagoshima, sexto filho de Kojiro e Kesa.

Com apenas doze anos, emigrou para o Brasil como filho adotivo do casal Kaichiro e Yuka Otsuji. Os motivos são incertos, mas creio que todos, ludibriados pelas propagandas de 
imigração, acreditavam realmente que fariam dinheiro em pouco tempo e retornariam para o Japão.

Os pais de Akie, Eiji e Ine Sakasegawa, assim como a irmã caçula de Ine, Mine, casada com Keisuke Makinodan, vieram na mesma embarcação, Kanagawa-maru, que desembarcou em Santos em 25 de abril de 1912. Outros parentes de Ine e Mine, Toichi, Natsu e Nagamori Narita também imigraram ao Brasil na mesma ocasião.

O casal Otsuji e meu avô foram para a fazenda São Manoel, segundo registros do Memorial do Imigrante. Uma boa parte da juventude de meu avô nos é desconhecida, em parte, porque ele não conversava sobre isso com os filhos, em parte, porque as relações com a família Otsuji não se estenderam aos descendentes. As memórias da família Otsuji concernentes ao meu avô não puderam ser recuperadas, uma vez que minha pesquisa começou após o falecimento dos envolvidos.

A filha Satiko e o irmão caçula de minha avó, Toshio, se lembram que Hideo comentava que, durante a juventude, havia trabalhado como copeiro em uma casa de família enquanto estudava à noite, em Santos. As coisas só vão ficar um pouco mais claras no momento em que ele se casou com minha avó, em 1932.

A memória da família Sakasegawa, no entanto, é mais detalhada.

Os pais de minha avó nasceram na província de Kaseda, em Kagoshima. Não sei muito sobre as vidas de seus pais, apenas que as famílias mantinham relações amigáveis, o que os levou a se casarem para emigrar para o Brasil. As famílias Sakasegawa e Narita (pais de Ine) tinham parentes e amigos (famílias Kijima, Makinodan e Maruno) que já haviam emigrado para o Brasil em 1908 no Kasato-maru, fato que talvez tenha contribuído em alguma medida para incentivar novas migrações de outros membros da família estendida.

Eiji nasceu em dezesseis de outubro de 1892, segundo filho de Soemon e Mune Sakasegawa, Ine nasceu em primeiro de abril de 1891, filha de Hanzaemon e Iso Narita (não 
sei quantos filhos eles tiveram, apenas que Ine era uma das mais novas, seguida de Mine).

John W. Connor (1977, p. 83) nota em seu estudo que a maioria dos imigrantes japoneses não eram filhos primogênitos, ou seja, não tinham direito à herança familiar.

Após o desembarque em Santos, em 1912, a família Sakasegawa morou em diversas cidades no interior paulista. Como era norma, trouxeram um filho adotivo consigo, Matsunosuke, que seguiu para a Argentina no intuito de encontrar os parentes que haviam emigrado para lá. Creio que as constantes mudanças de endereço indicam os desafios da adaptação num ambiente desconhecido.

Segundo o filho Toshio, o primeiro destino da família Sakasegawa foi a estação Santa Ernestina, no município Taquaritinga, de onde fugiram após pouco tempo, devido às péssimas condições de trabalho. Para os senhores do café, que, não havia muito, tinham perdido a mão-de-obra escrava, os imigrantes japoneses iriam preencher aquelas senzalas. Logo, o contraste de visões tornou-se insuportável para os imigrantes que chegaram ainda perto de 1908, ou seja, quando a colônia ainda era incipiente e as políticas locais, desfavoráveis. Nos primeiros anos da imigração japonesa no Brasil, ainda não estavam estabelecidas as associações de assistência ao imigrante, que Boris Fausto chama de microssociedades, que, mais tarde, terão papel fundamental na adaptação do imigrante no país receptor.

\footnotetext{
A referência aos laços de grupo diz respeito à organização de microssociedades, situadas a meio caminho entre as esferas pública e privada, como é o caso dos clubes comunitários, teatros, associações de socorros mútuos formadas por pessoas de uma determinada etnia ou de uma determinada região do país de origem, sindicatos, templos religiosos etc. (FAUSTO, 1998, p. 28)
}

De acordo com Tomoo Handa (1987, p. 101-103), a incerteza de uma boa colheita aliada à impossibilidade de cultivar produtos para subsistência foram fatores que favoreciam 
as fugas dos imigrantes das fazendas. Outros fatores como os muitos boatos (de vidas melhores) também são mencionados.

Após deixar a fazenda, a família Sakasegawa foi para São Paulo, onde Eiji trabalhou como carpinteiro/marceneiro para o industrial Francisco Matarazzo na fábrica do bairro do Belém. Ine, por sua vez, fazia trabalhos domésticos na residência de uma família francesa na Avenida Paulista. A primeira filha nasceu morta e foi enterrada no cemitério do Araçá (na época, mais popular), em 1912.

No ano seguinte, o casal mudou-se para Iguape, quando Eiji recebeu um lote de terra da companhia de imigração japonesa, Brazil Takushoku Kaisha, na colônia Katsura. Esse empreendimento teve como uma de suas figuras fundadoras, o ilustre Eiichi Shibusawa (Nihonjin no Nanbei ni Hattenseshimu, 2008). Um forte motivo para essa mudança, além da oportunidade de cultivar a terra de forma justa, foi o fato de que nessa colônia havia diversas famílias provenientes do mesmo local que o casal Sakasegawa, a província de Kaseda, em Kagoshima.

Na fazenda Jipovura, cultivaram arroz e cana-de-açúcar, que, com um alambique, transformavam em pinga, açúcar mascavo e álcool bruto.

A primeira filha, Akie Sakasegawa, nasceu em cinco de junho de 1914. A segunda, Hamako, em quatro de abril de 1919.

Segundo Toshio, Eiji contava que havia sido a época mais próspera e feliz de sua vida. Segundo relatórios do administrador da colônia, Masao Hashida, as contas da família Sakasegawa eram positivas e a perspectiva de enriquecimento, promissora. Esses documentos estão na National Diet Library de Tóquio.

Mas, devido à contínua sucumbência à malária, principalmente de Eiji, que contava mais de sete vezes, venderam tudo para uma família de amigos e vizinhos, Namba, e se mudaram para Santos, em 1922. 
No litoral, Eiji trabalhou na construção civil como auxiliar de engenharia. Nasceram os filhos: Matsuo, em cinco de janeiro de 1924, Tomiko, em dezoito de setembro de 1926, e Munenori, em três de julho de 1929.

A construção da malha ferroviária estadual levou a família Sakasegawa para a região de Araçatuba em busca de trabalho. Os irmãos (Keikichi, Eizo, Eiji) Ohara, que também vieram de Kagoshima no Kanagawa-maru em 1912, pretendiam abrir uma agência de caminhões e convidaram Eiji para dirigir a manufatura das carrocerias. Enquanto esse empreendimento não vingava, Eiji trabalhou no armazém de secos e molhados da família Ohara (Figura 31). Nessa época, devem ter reencontrado Hideo Matsuyama, que havia vindo na mesma embarcação do Japão.

Akie casou-se com Hideo em 1932. Moraram em Avanhandava de 1932 a 1946, onde tiveram quatro filhos: Deicy, em seis de abril de 1933, Satiko, em cinco de janeiro de 1935, Milton, em primeiro de janeiro de 1937, e Luci, em vinte e nove de abril de 1938, e em Lins de 1946 a 1959, onde nasceram: Neli, em trinta de novembro de 1947, e Luiz Masao, em dezenove de abril de 1951, enquanto Hideo trabalhava como mestre-de-obras para a Estrada de Ferro Noroeste do Brasil (NOB), no trecho Bauru - Araçatuba. Mudaram-se para São Paulo no fim de 1959, quando Hideo aposentou-se como funcionário público da rede ferroviária federal. Hideo faleceu em dez de novembro de 1962, vítima de carcinoma do estômago.

De volta à família Sakasegawa, no começo da década de 1930, moraram em Guararapes, onde Eiji trabalhou no armazém dos irmãos Ohara. O filho Toshio nasceu em oito de abril de 1934 .

Mudaram-se para Mirandópolis, onde Eiji administrou a Fazenda São Joaquim (Figura 32), também dos irmãos Ohara, quando o negócio de caminhões não se realizou. Voltaram a Guararapes em 1947, onde Eiji abriu um armazém de secos e molhados. Como 
esse empreendimento foi à falência, a família Sakasegawa rumou para a Fazenda Santa Rita, para lavoura de batata, dentre outros legumes e frutas, à convite do cunhado Makinodan. Mudaram-se para Cotia em agosto de 1948 para lavoura de alcachofra, com o meeiro de Shigeru Matsuoka, associados à Cooperativa Agrícola de Cotia. Nesse período, a família Sakasegawa também cultivou batata e tomate.

Eiji faleceu em três de setembro de 1952, vítima de micose pulmonar.

O restante da família se mudou em 1969 para Engenheiro Goulart, em São Paulo, na ocasião do casamento de Munenori, cuja noiva era de Guarulhos.

No começo da década de 1970, Ine e família mudaram-se, ainda, para Arujá, para cultivar verduras e legumes.

Ine adoeceu em 1971 e a filha Tomiko cuidou dela até os últimos dias. Ine faleceu em dez de novembro de 1974.

\subsection{Histórias da fotografia}

Como notou Geoffrey Batchen (2001), as fotos produzidas em âmbito familiar, as fotos vernaculares, não figuram amplamente nas histórias da fotografia ou em museus. Dois motivos principais podem ser apontados: a, razoavelmente comum, falta de ambição artística e a multiplicidade, semi-esquizofrênica, de formas e discursos fotográficos.

Uma exceção está em The new history of photography, editada por Michel Frizot (1998, p. 679-685), fato que Batchen também ressaltou. Nesse volume maciço, apenas sete páginas são dedicadas ao álbum fotográfico. Uma contém um artigo de Frizot, The universal album, onde ele delineou um panorama do álbum fotográfico, destacando sua importância histórica e mostrando diretrizes de interpretação. Na mesma página, há uma reprodução de uma página de um álbum. Nas duas seguintes, há uma colagem com fotos pequenas $(3 \mathrm{x} 4 \mathrm{~cm}$ 
até 10 x $15 \mathrm{~cm}$, aproximadamente). E, nas últimas quatro, há reproduções de sete páginas de álbuns diversos. Em suma, extremamente curto em relação aos outros capítulos do tomo.

Outros exemplos são as enciclopédias fotográficas da Routledge (WICKENSFELDMAN; FOGARASI, in: HANNAVY, 2008; WICKENS-FELDMAN, in: WARREN, 2006), uma enciclopédia da George Eastman House (MULLIGAN and WOOTERS, 2000) e a história da fotografia editada por Jean-Claude Lemagny e André Rouillé (HASSNER, in: LEMAGNY y ROUILLÉ, 1988). No entanto, elas se concentram quase exclusivamente na história do desenvolvimento das tecnologias fotográficas.

Desse modo, as fotos de famílias figuram apenas timidamente na história da fotografia. Lentamente, a sociologia e a antropologia, os estudos culturais ou materiais, foram demonstrando mais interesse nas fotografias de famílias. A compilação de Stacey McCarroll Cutshaw e Ross Barrett (2008) oferece uma visão panorâmica sobre os estudos sobre fotografia vernacular, além de uma extensa bibliografia.

As escolhas para compra de uma câmera, no Brasil do começo do século XX, eram limitadas. As câmeras tinham de ser importadas, portanto, não eram baratas (principalmente para os imigrantes), e eram vendidas em poucos estabelecimentos especializados.

Em uma entrevista estruturada com Satiko, utilizando os volumes de Todd Gustavson (2009) e Brian Coe e Paul Gates (1977), ela me indicou prováveis câmeras que Hideo teria possuido: Folding Pocket Kodak, Vest Pocket Kodak, Ensign Midget, Butcher's Carbine camera, Houghton’s Bo 3 Ensign camera, Houghton’s Ensignette camera, Hawkette camera, Rajar No 6 camera, Ebner camera. Esse é, aparentemente, o modelo. Mas, facilmente, poderia ser ainda de outras marcas mais comuns na América do Sul, como Yashica e Voigtländer.

Todos esses modelos possuem erros de paralaxe, ou seja, o visor por onde se enquadra não corresponde à lente que registra a película. Desse modo, os enquadramentos possíveis são aproximados, nunca exatos. Além disso, o foco não podia ser ajustado na lente, 
assim, o fotógrafo não vê se o objeto está ou não em foco. O foco devia ser ajustado através de uma rosca lateral que indica as distâncias possíveis. Por fim, além de impreciso, o visor era escuro. Comparadas aos modelos atuais, não parece que era muito fácil operar essas câmeras. Por isso, é comum encontrar fotos onde o objeto está fora de foco, ao contrário do fundo, ou fotos nas quais o foco simplesmente não está bem feito (Figuras 10, 12, 14, 17, 19, 21 e 33). $\mathrm{Ou}$, ainda, fotos onde o objeto não está bem enquadrado (cortes estranhos que deixam parte da cabeça ou dos membros de fora).

Pela falta de ambição artística, as fotos vernaculares nem sempre são bem executadas. Michel Frizot vê como características da foto de família: "foco malfeito, erros na composição e falhas técnicas" (1998, p. 679). Evidente que problemas como esses não são deliberados, muitas vezes eles decorrem das limitações impostas pelo equipamento fotográfico.

Marvin Heiferman, por outro lado, vê nesses acidentes não só as características marcantes das fotos amadoras ou vernaculares, mas também como algo que as separa do universo da fotografia profissional, onde erros são simplesmente obliterados.

Os resultados da inexperiência - a inclusão de detalhes inesperados, horizontes inclinados, cortes excêntricos, borrões sobrenaturais, duplas exposições, vazamentos de luz e sombras inesperadas - são, em grande medida, o que faz dos instantâneos tão imprevisíveis, amáveis e deleitosos de se olhar. (HEIFERMAN, 2008, p. 47)

Durante a Segunda Guerra Mundial, não era permitido aos imigrantes possuir, dentre outras coisas, câmeras fotográficas. Hideo enterrou, então, a sua. Após o fim da guerra, Hideo pôde, outra vez, comprar uma câmera. Ele parece ter escolhido uma semelhante à antiga, segundo Satiko, que, por sua vez, tinha uma versão da Brownie. Como recorda Heiferman, a Brownie, da Eastman Kodak Company, era direcionada ao público infantil, e, assim, era de 
fácil manuseio (2008, p. 42), mas não possuía muitos recursos, como ajustes de foco e de velocidade, por exemplo.

O fato de Hideo ter tido uma câmera contribui, obviamente, para certa abundância de fotos. Existem muitos motivos para se ter uma câmera e tirar fotos, mas, creio que, para ele, por morar tão longe de seus pais e irmãos, a fotografia era especialmente importante para manter os laços familiares. "Quanto mais distante as pessoas estão, e quanto mais raro elas se veem, tão mais importante se torna o ato de fotografar e remeter fotos.” (ROSE, 2010, p. 46)

Além das fotos vernaculares produzidas por Hideo, existem muitos retratos dele que foram comissionados por estúdios profissionais (Figuras 22 e 34). Pelo fato de ter deixado a terra natal com tão pouca idade, as mudanças nos traços de seu semblante só podiam ser acompanhadas por sua família no Japão através de fotografias.

Em uma das entrevistas não estruturadas, com fotografias, Toshio também mencionou um fotógrafo profissional que seu pai, Eiji, sempre contratava. Seu nome era Okigawa e residia próximo a Mirandópolis. Não foi possível identificar nenhuma foto realizada por ele, devido à falta de marcas ou de anotações. Suspeito, no entanto, que as fotografias com dimensões em torno de 15 x $20 \mathrm{~cm}$ sejam de sua autoria (Figuras 11 e 13). Como também notou Frizot, grandes ampliações não eram comuns, portanto, a chapa fotográfica e o papel fotográfico deveriam possuir dimensões semelhantes. As câmeras amadoras utilizavam filmes 120 (6 centímetros de altura), apenas câmeras profissionais poderiam suportar chapas maiores ( 4 x 5 polegadas, por exemplo).

A importância de fotógrafos profissionais itinerantes está no fato de que seus retratos podem ser realizados em ambientes domésticos familiares. O que, apesar de não tornar o ato fotográfico muito mais confortável para os retratados, pelo menos, localiza-os em sua moradia ou em um lugar familiar. Muitos imigrantes não possuíam condições financeiras de ter uma câmera, portanto, a visita de um fotógrafo podia ser um acontecimento extraordinário. 


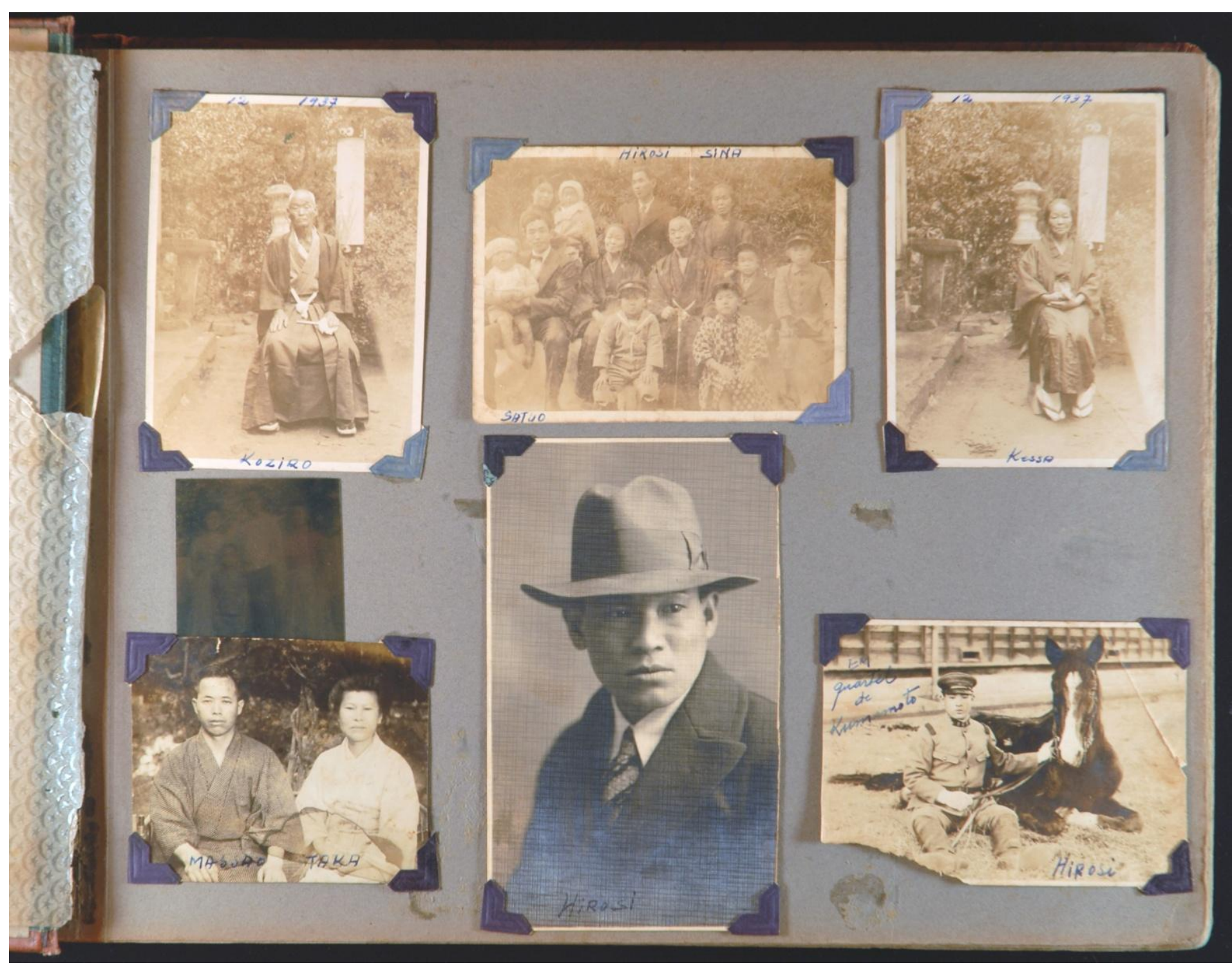

FIGURA 1. Primeira página do álbum da família Matsuyama 


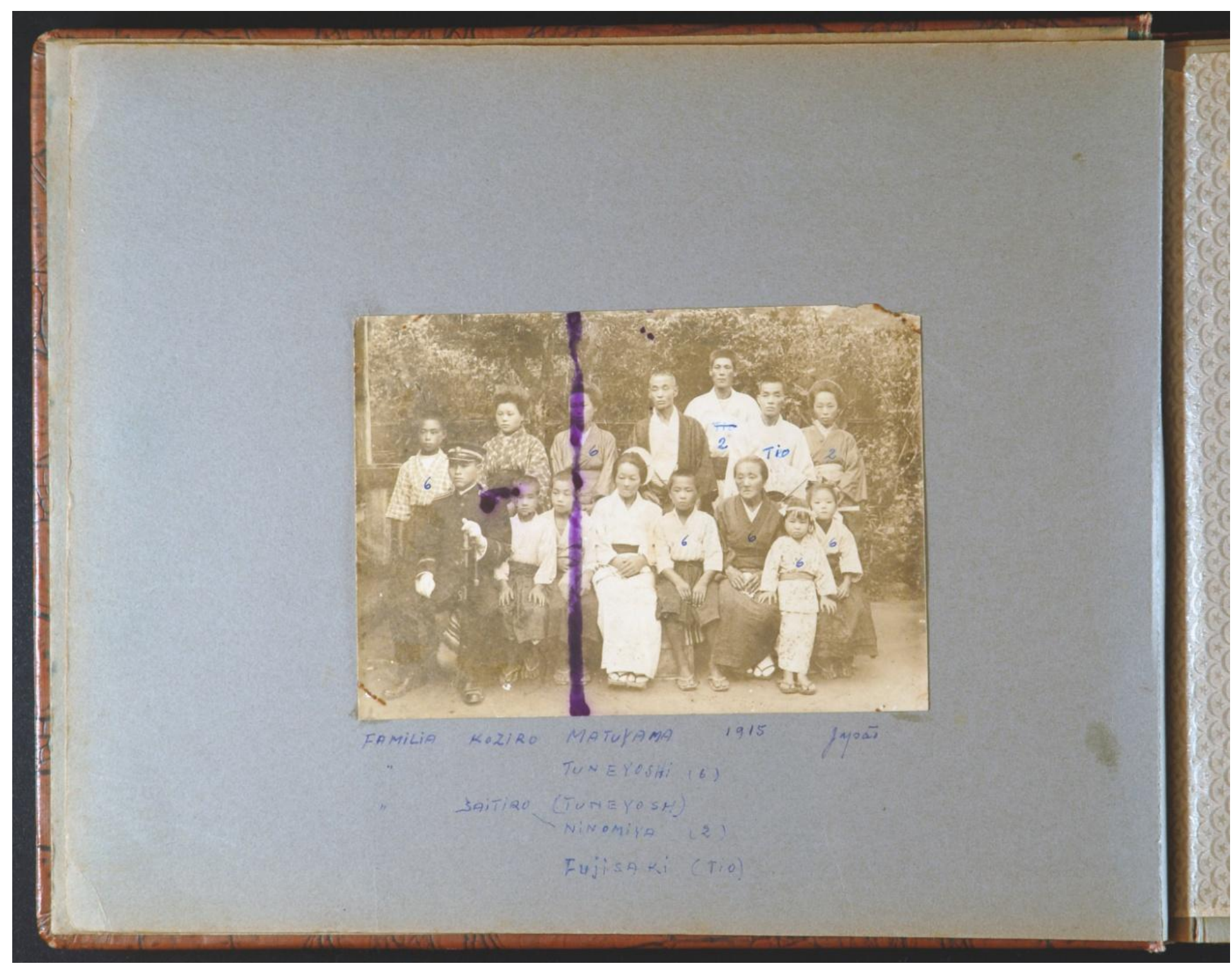

FIGURA 2. Segunda página do álbum da família Matsuyama 


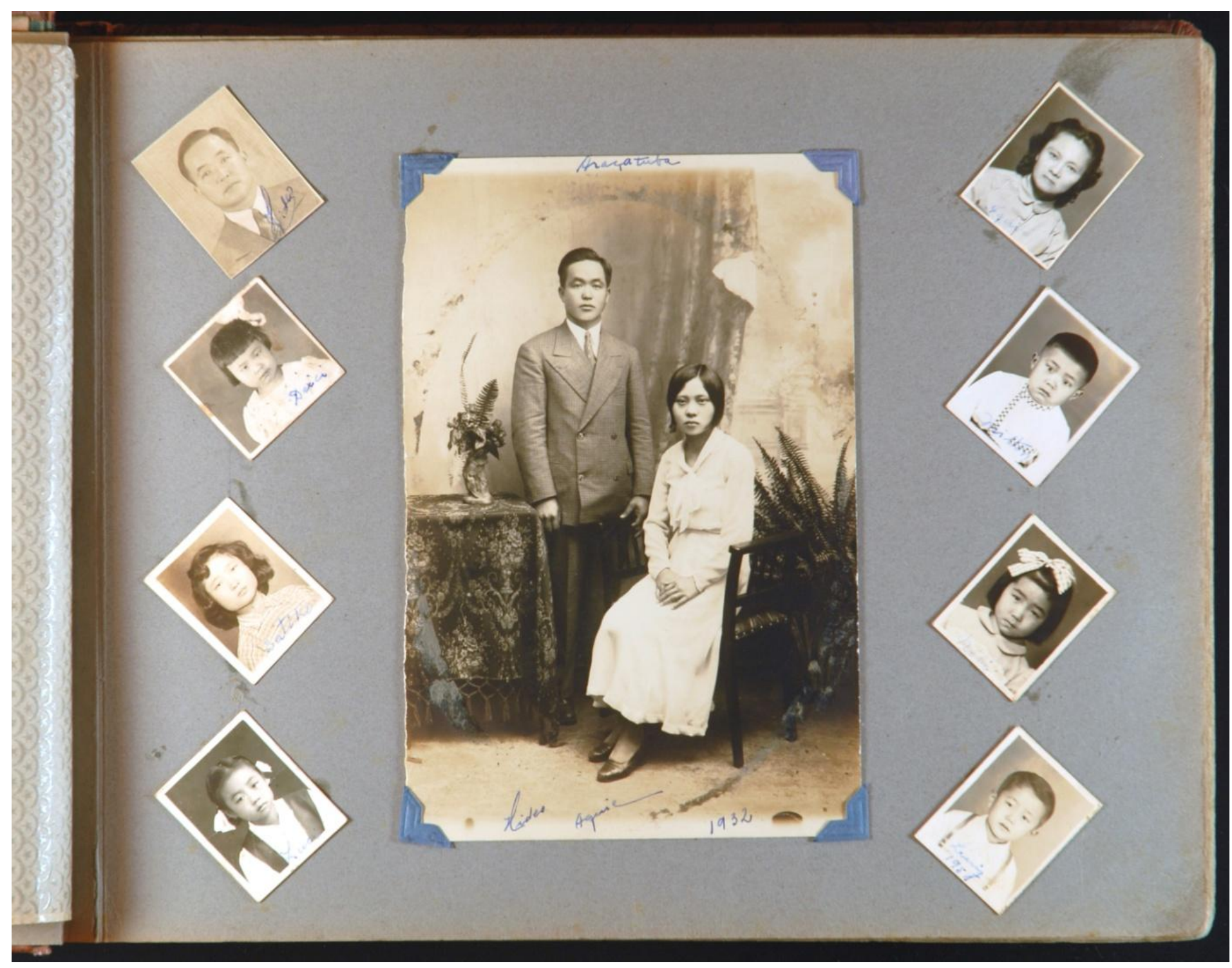

FIGURA 3. Terceira página do álbum da família Matsuyama 


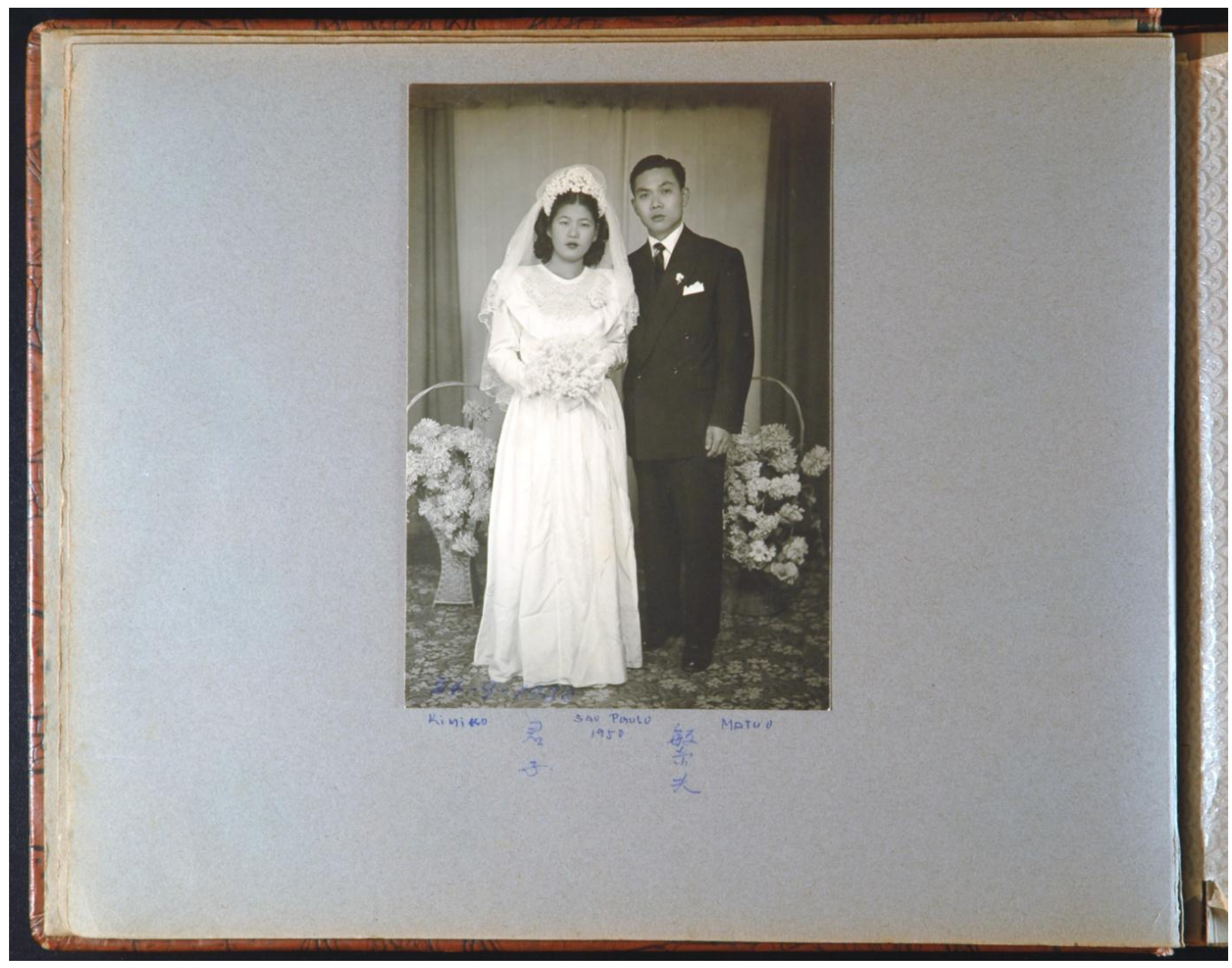

FIGURA 4. Quarta página do álbum da família Matsuyama 


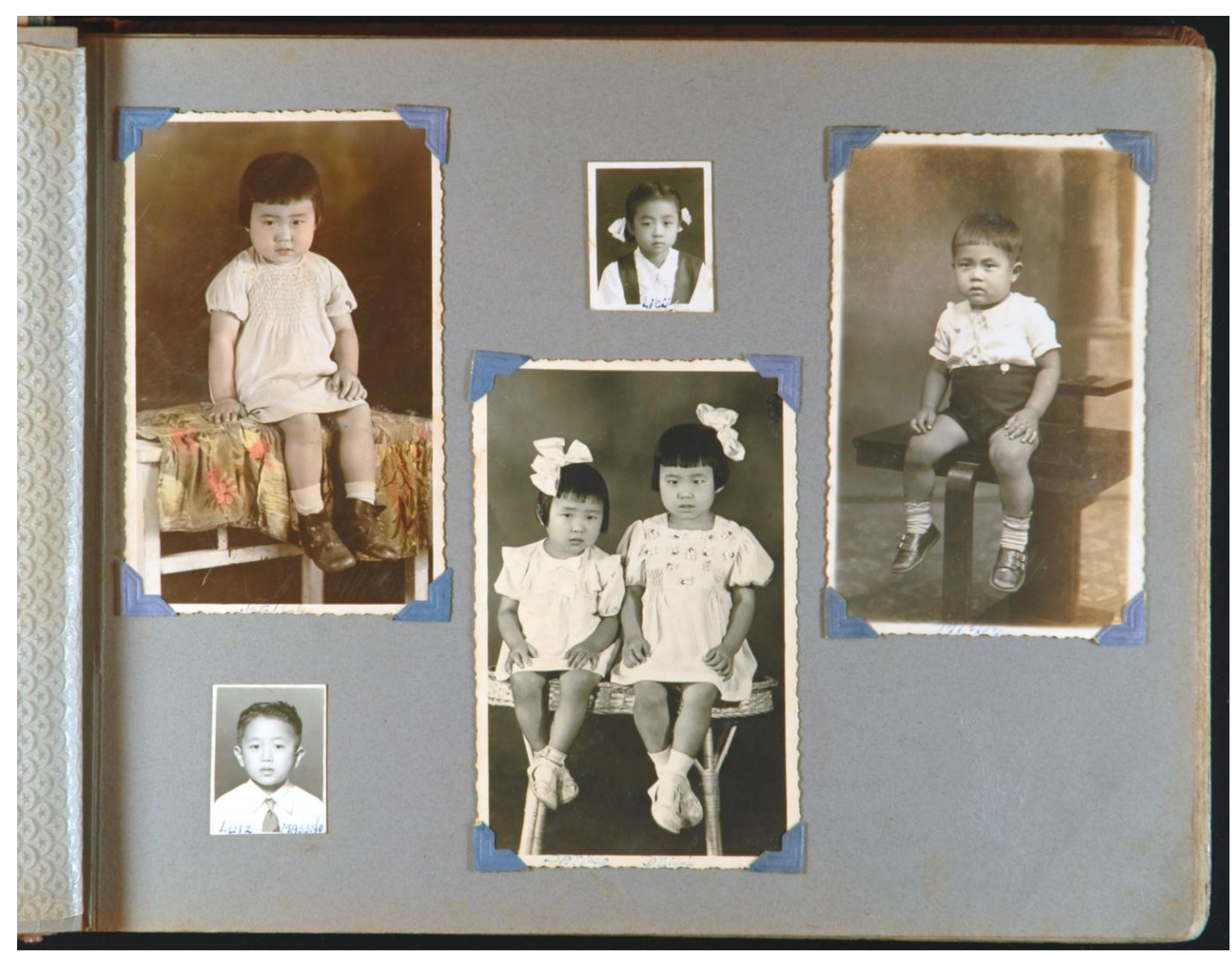

FIGURA 5. Sétima página do álbum da família Matsuyama 


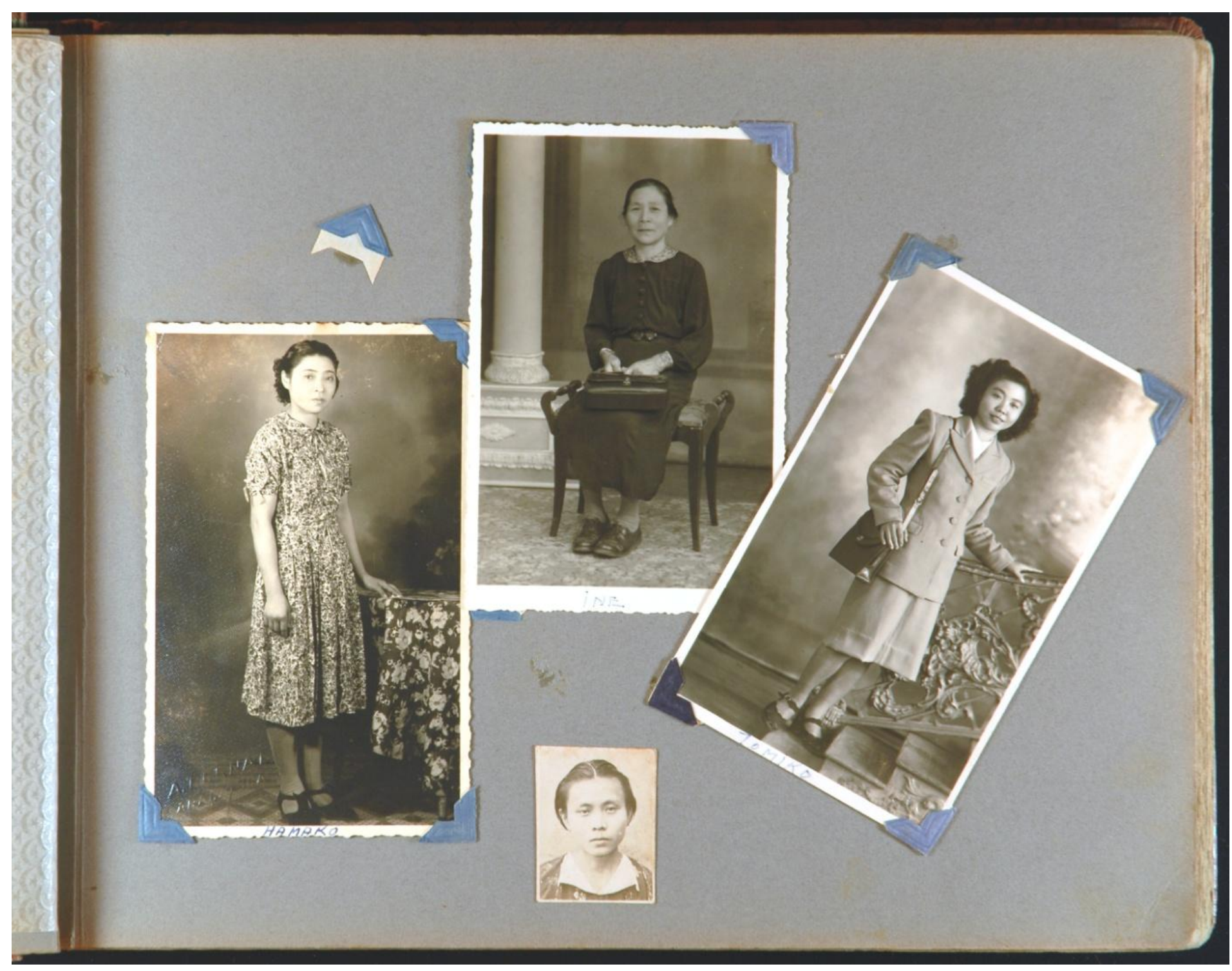

FIGURA 6. Nona página do álbum da família Matsuyama 


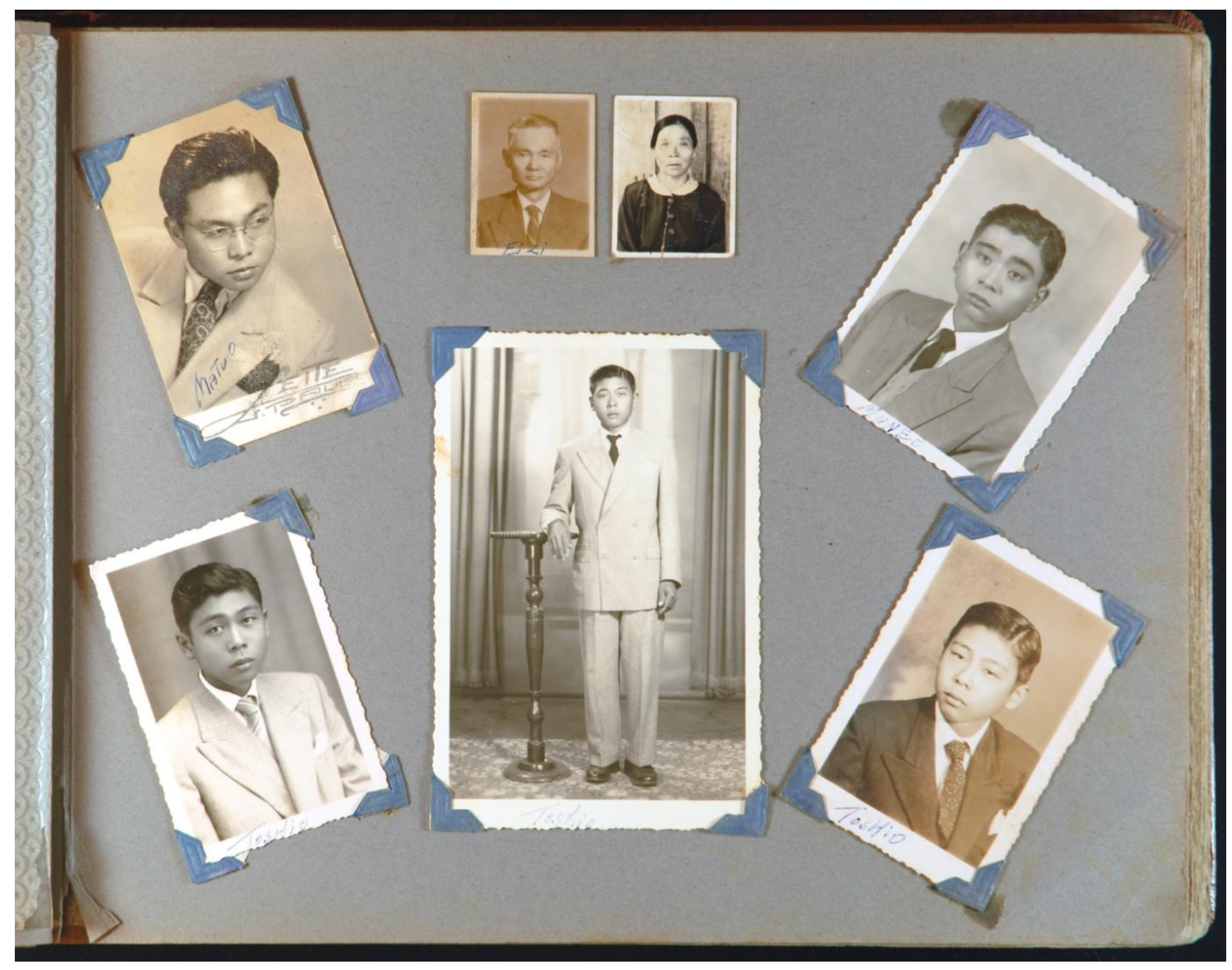

FIGURA 7. Décima primeira página do álbum da família Matsuyama 


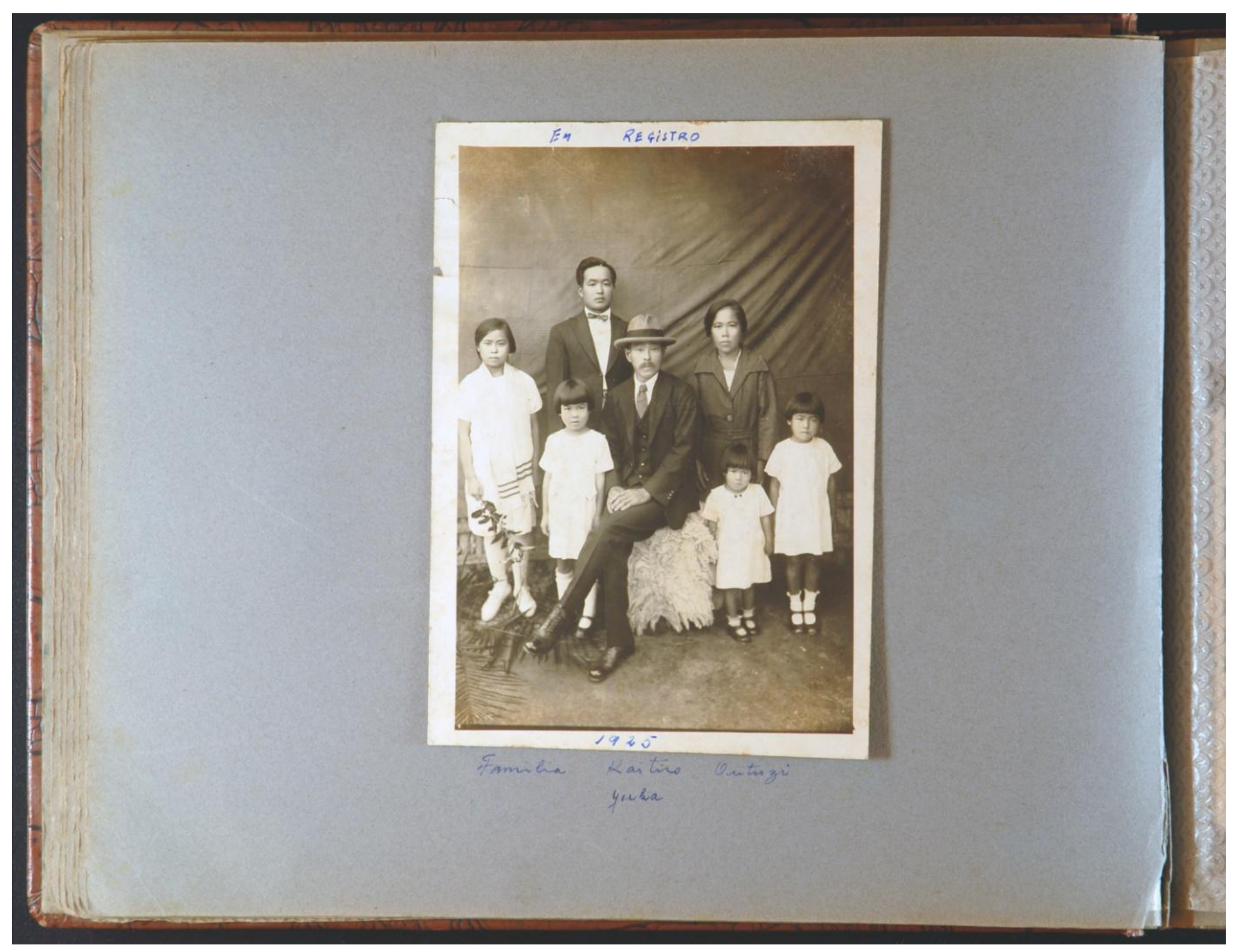

FIGURA 8. Décima segunda página do álbum da família Matsuyama 


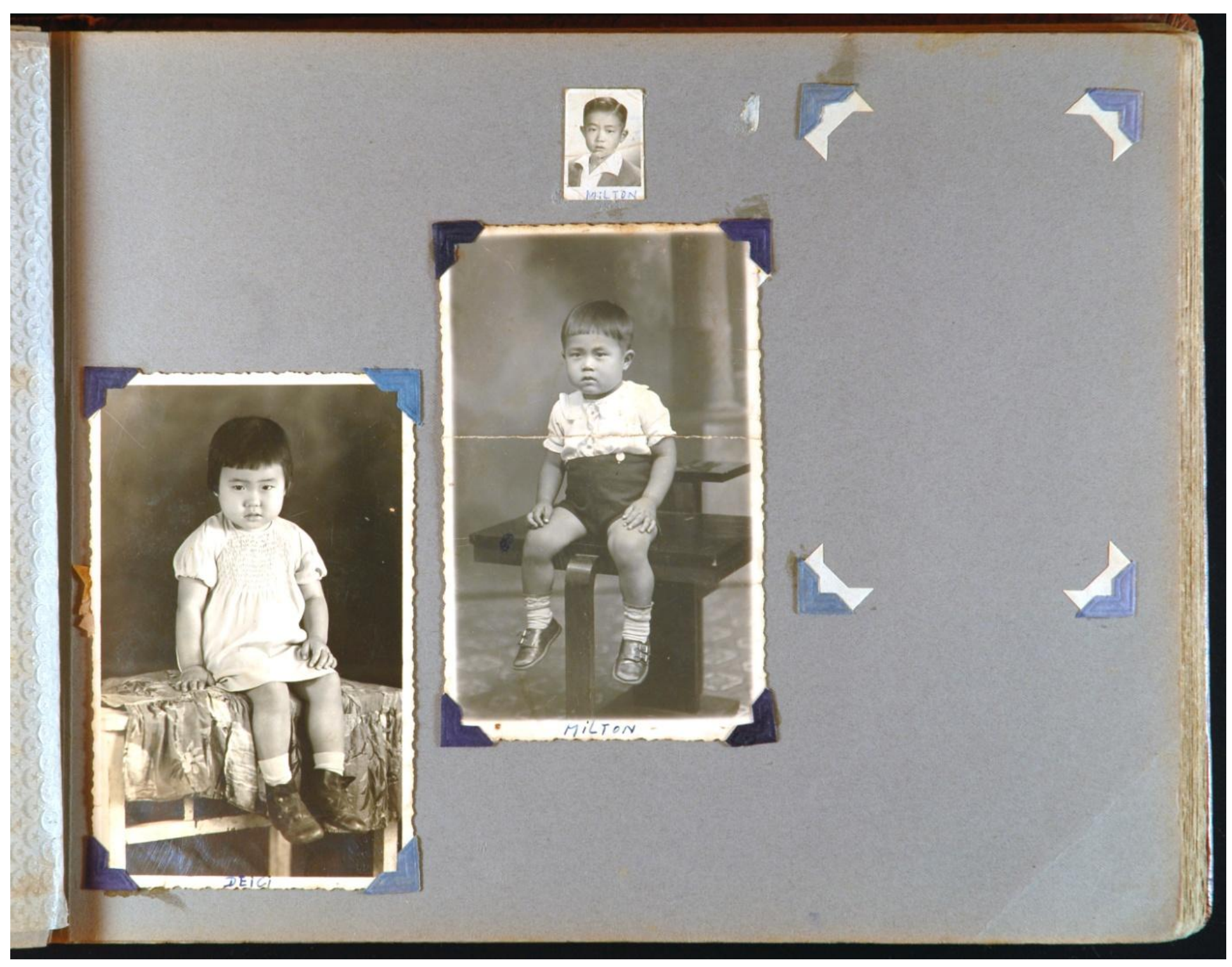

FIGURA 9. Décima terceira página do álbum da família Matsuyama 


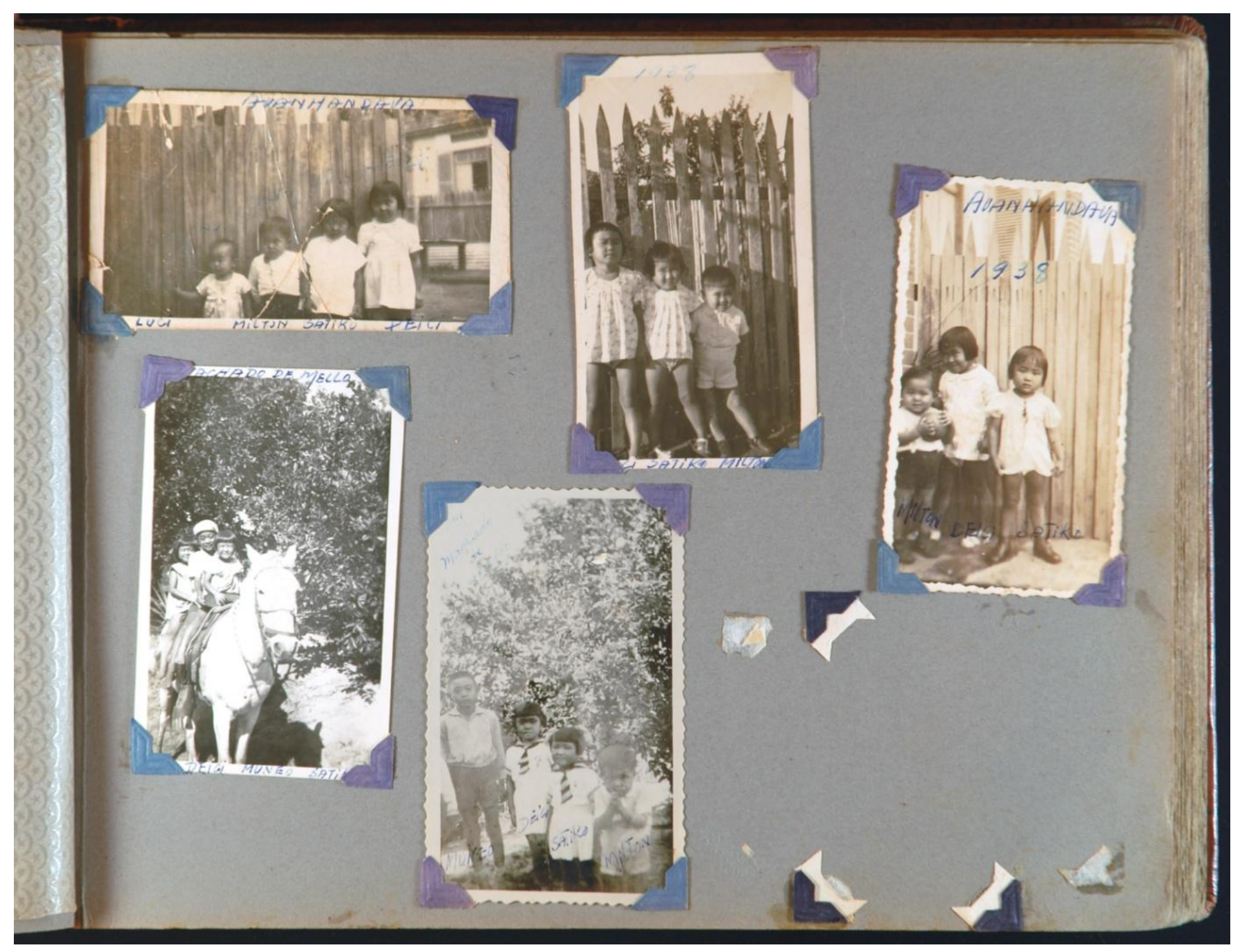

FIGURA 10. Décima quinta página do álbum da família Matsuyama 


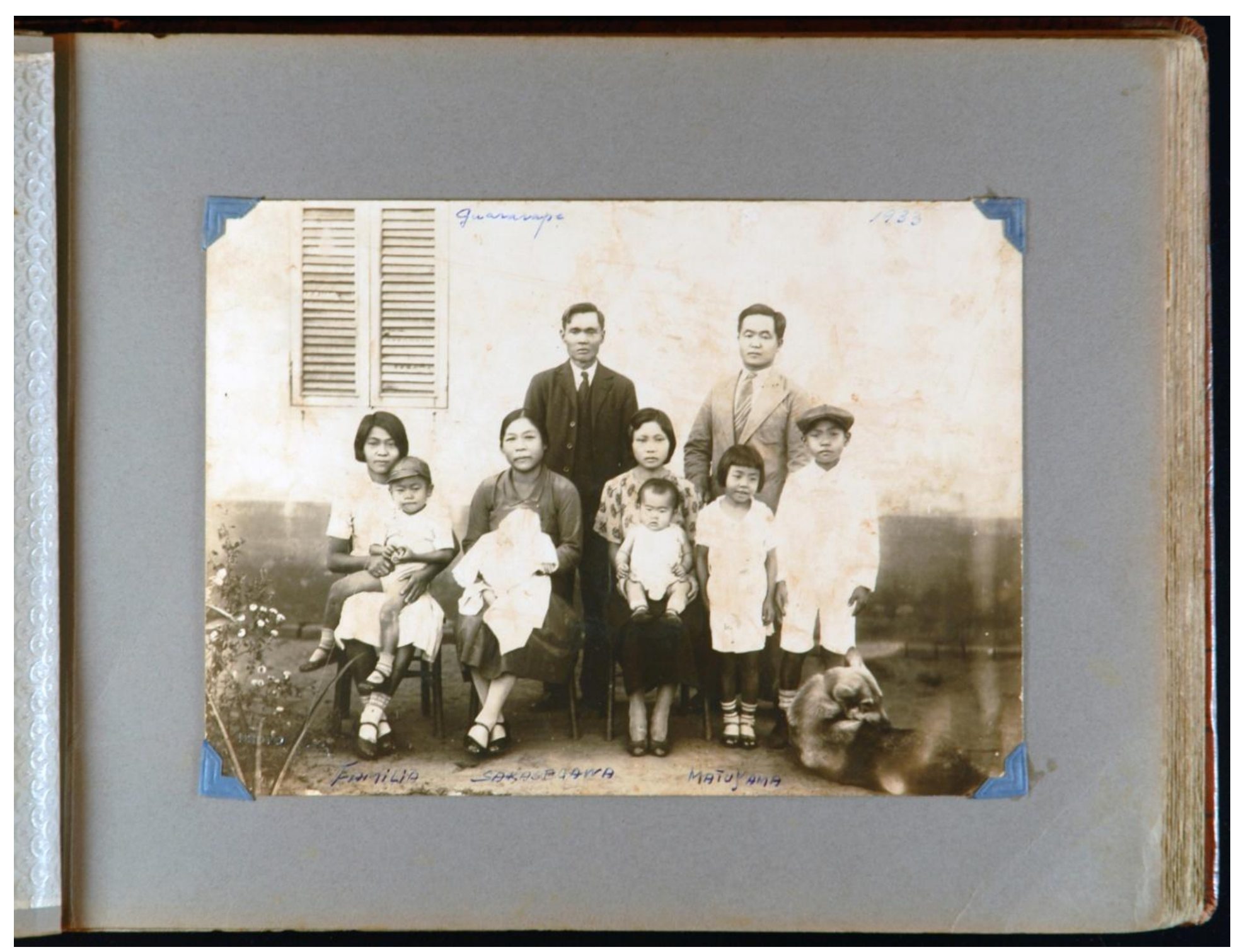

FIGURA 11. Décima sétima página do álbum da família Matsuyama 


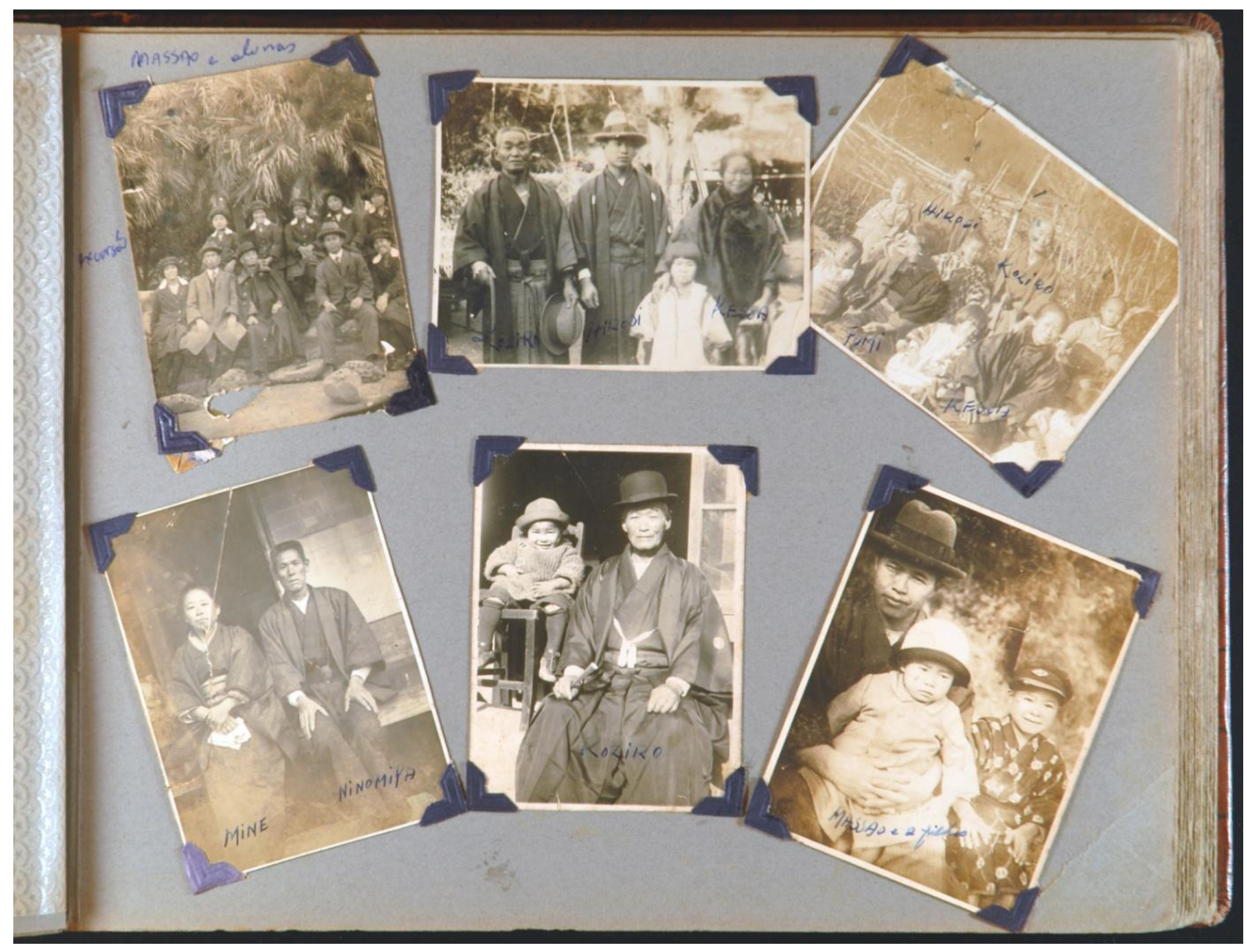

FIGURA 12. Décima nona página do álbum da família Matsuyama 


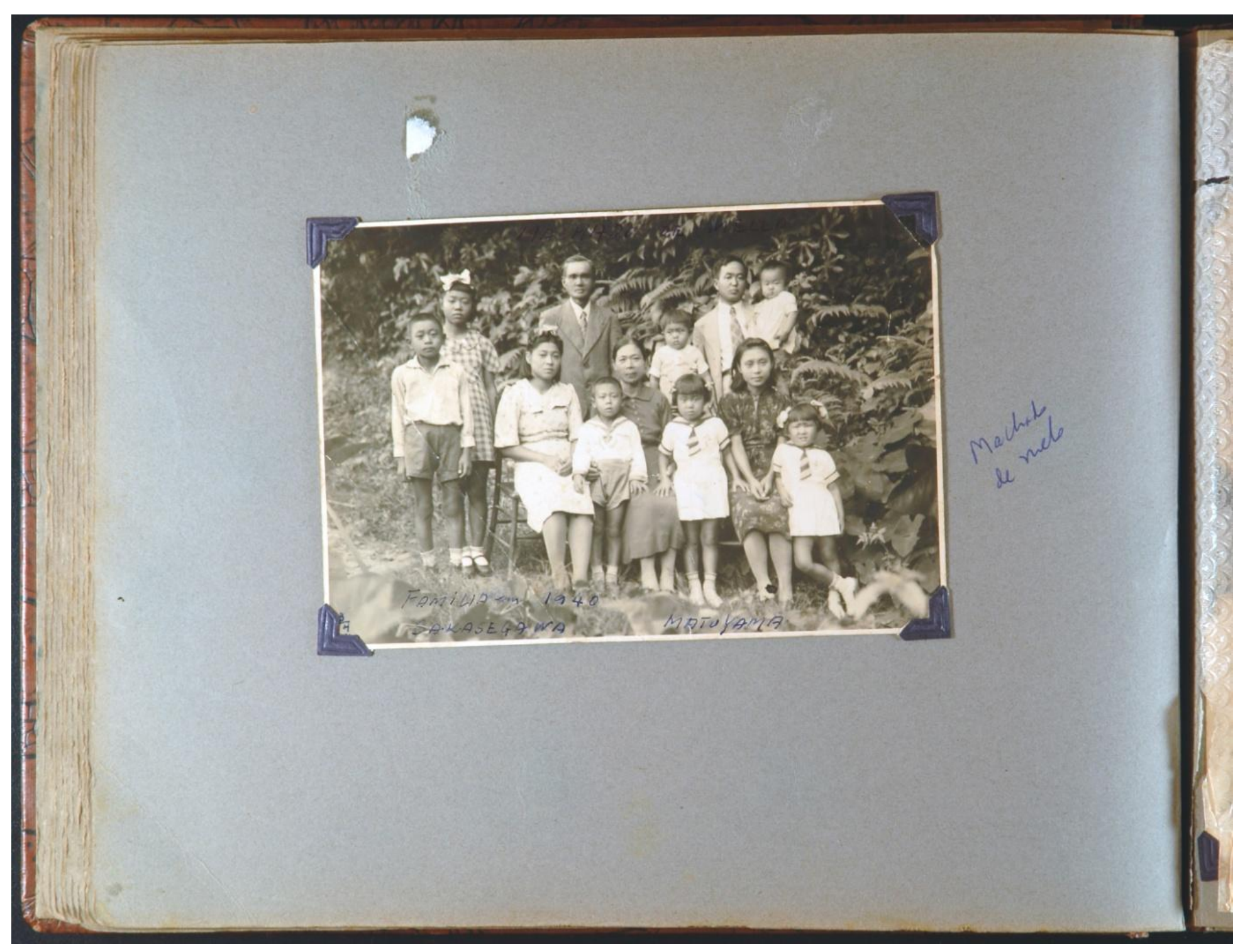

FIGURA 13. Vigésima página do álbum da família Matsuyama 


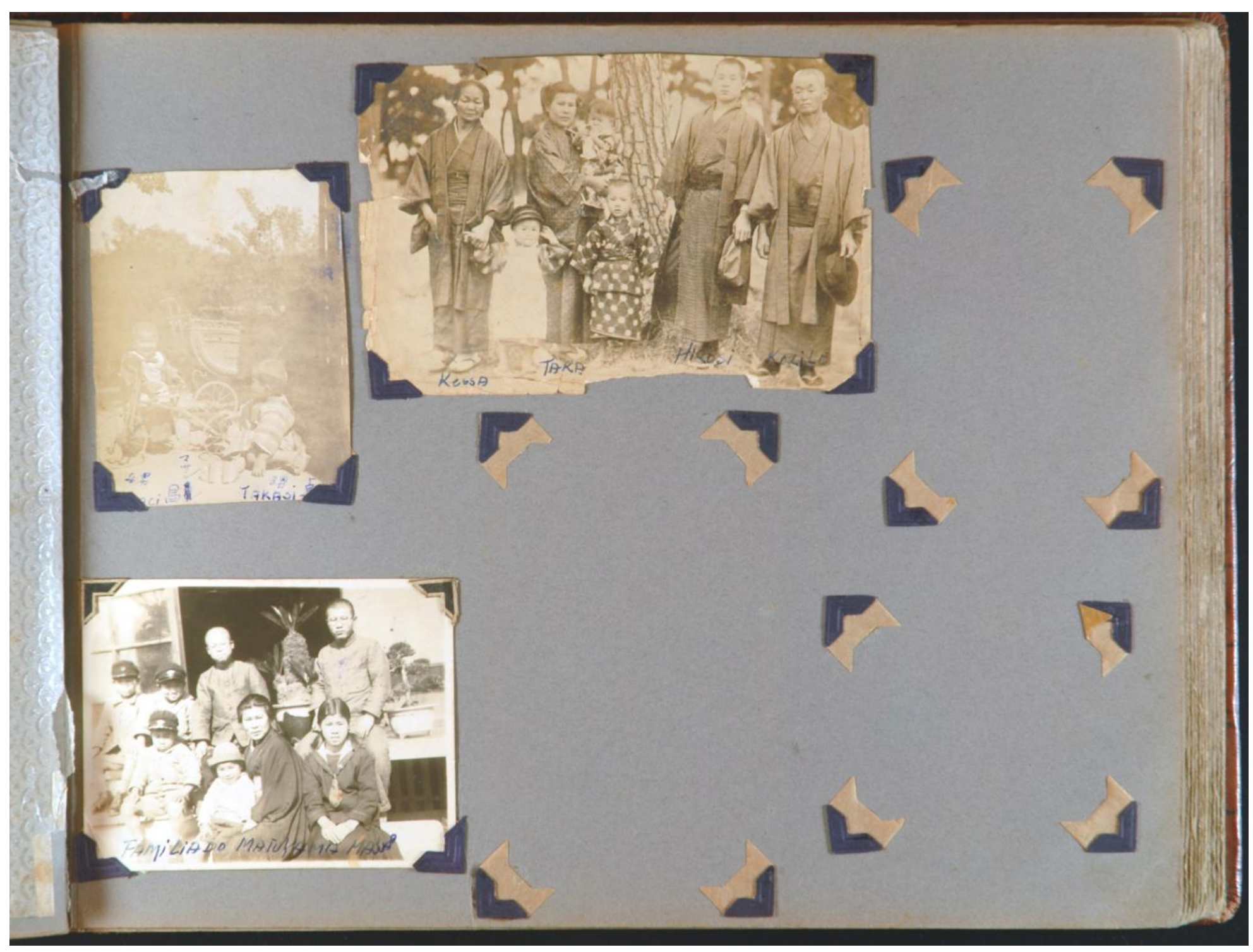

FIGURA 14. Vigésima primeira página do álbum da família Matsuyama 


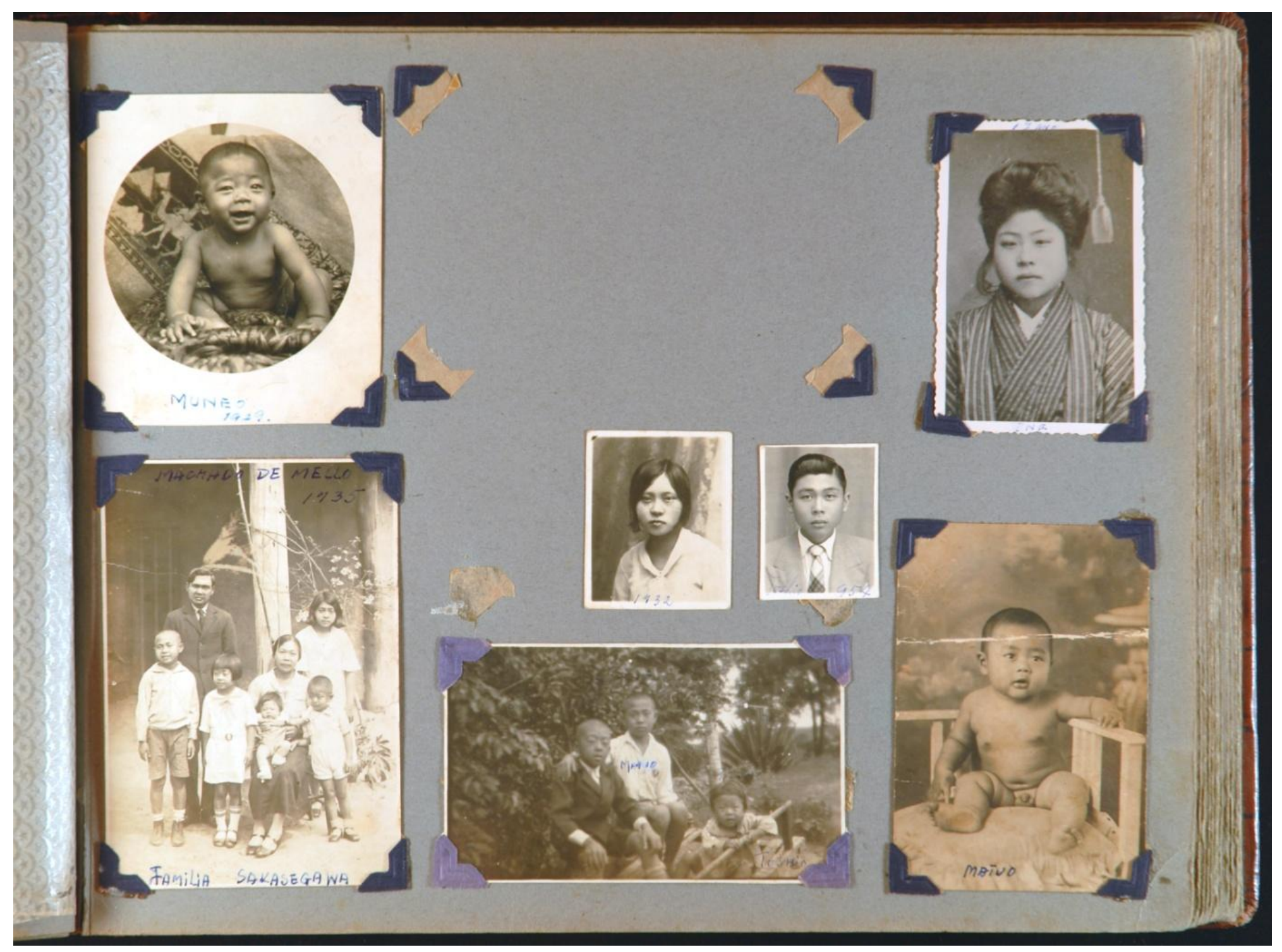

FIGURA 15. Vigésima terceira página do álbum da família Matsuyama 


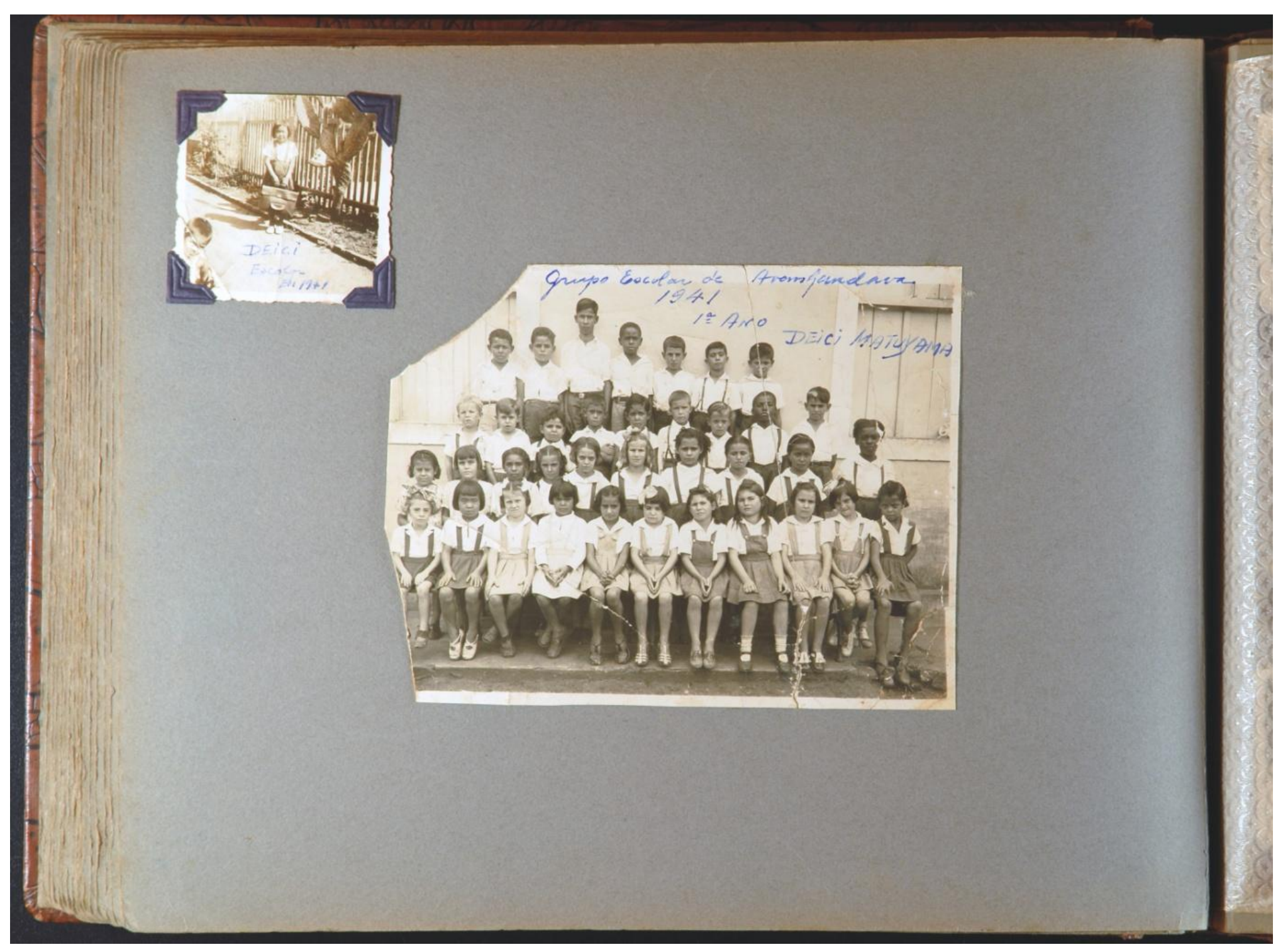

FIGURA 16. Trigésima página do álbum da família Matsuyama 


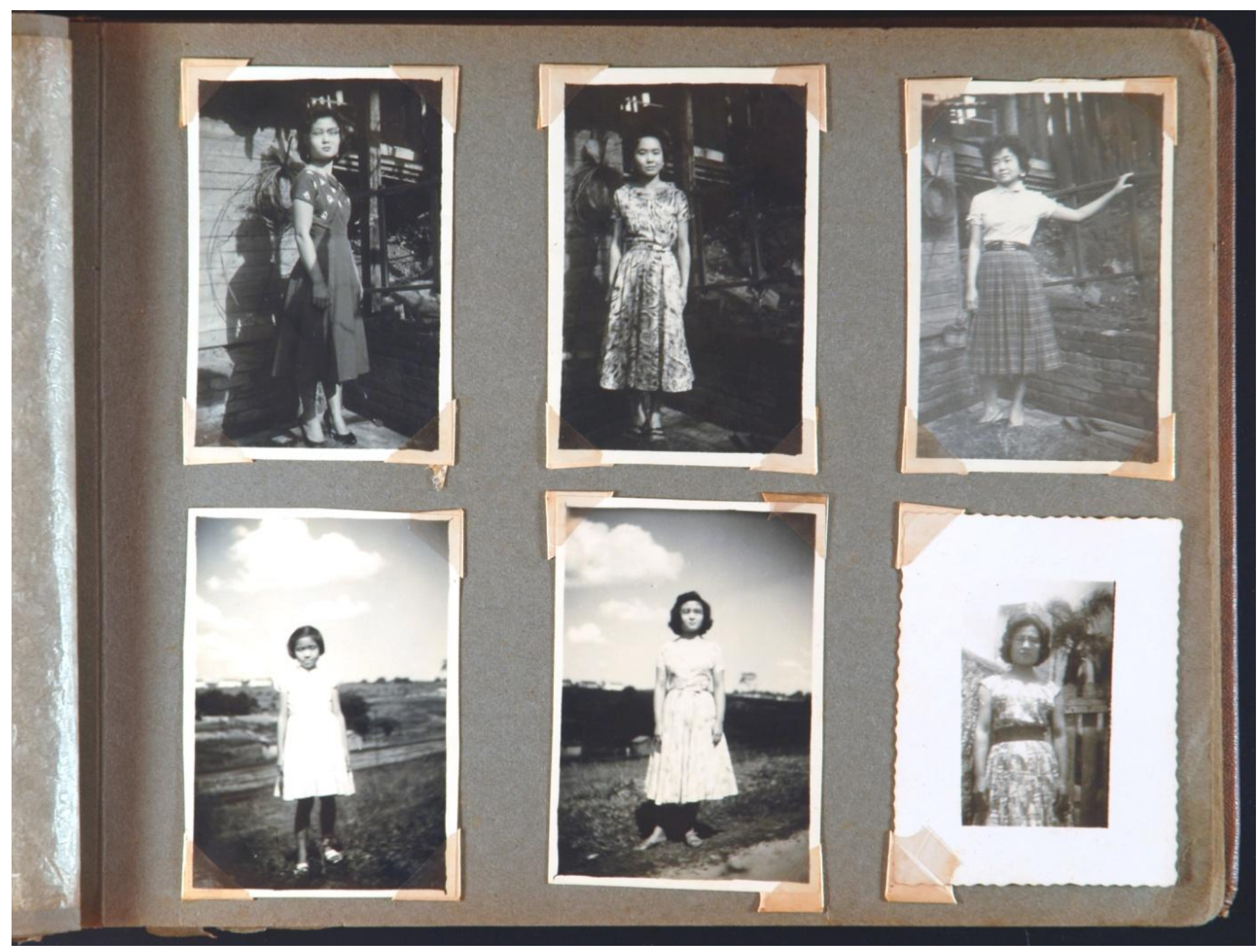

FIGURA 17. Nona página do outro álbum da família Matsuyama 


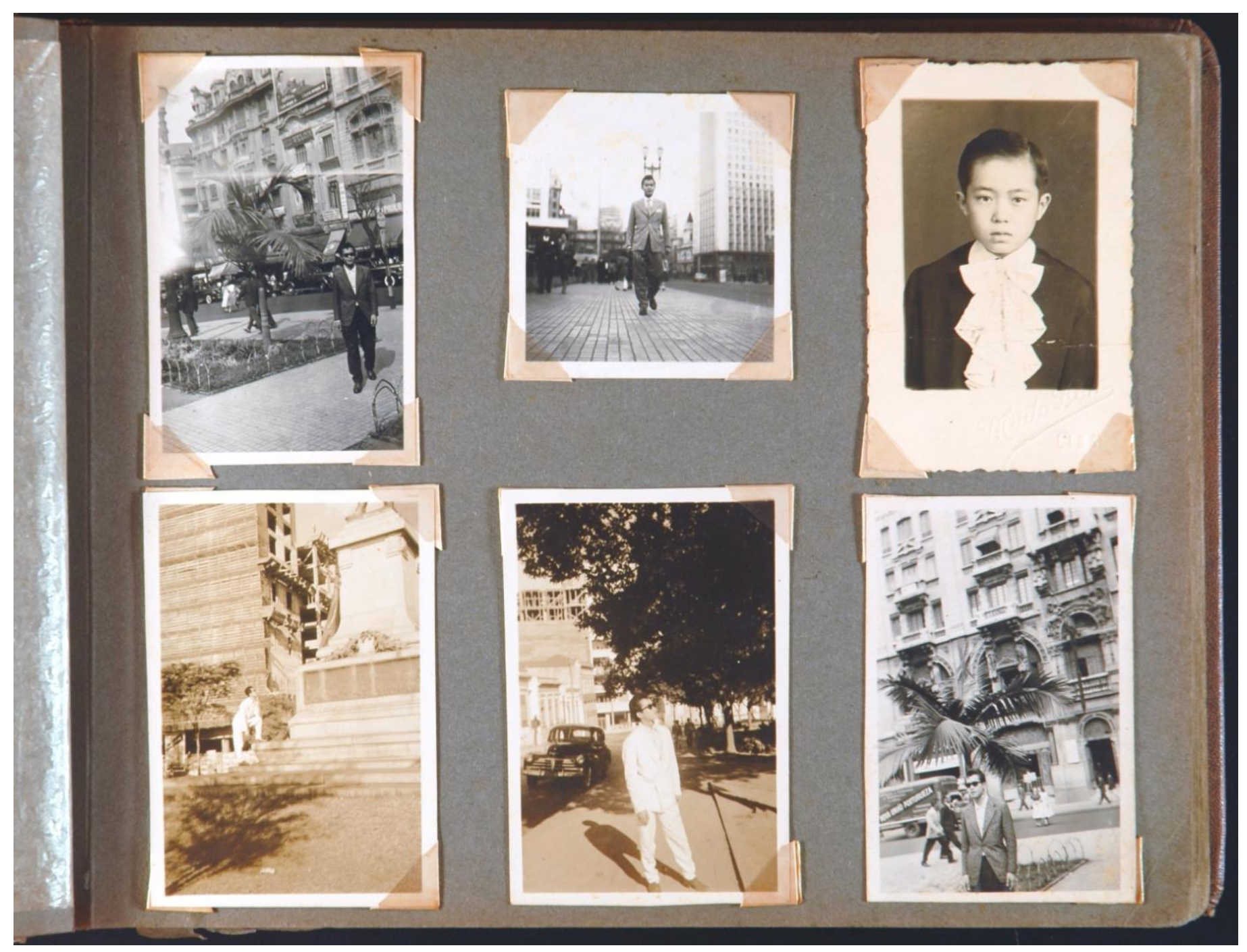

FIGURA 18. Décima primeira página do outro álbum da família Matsuyama 


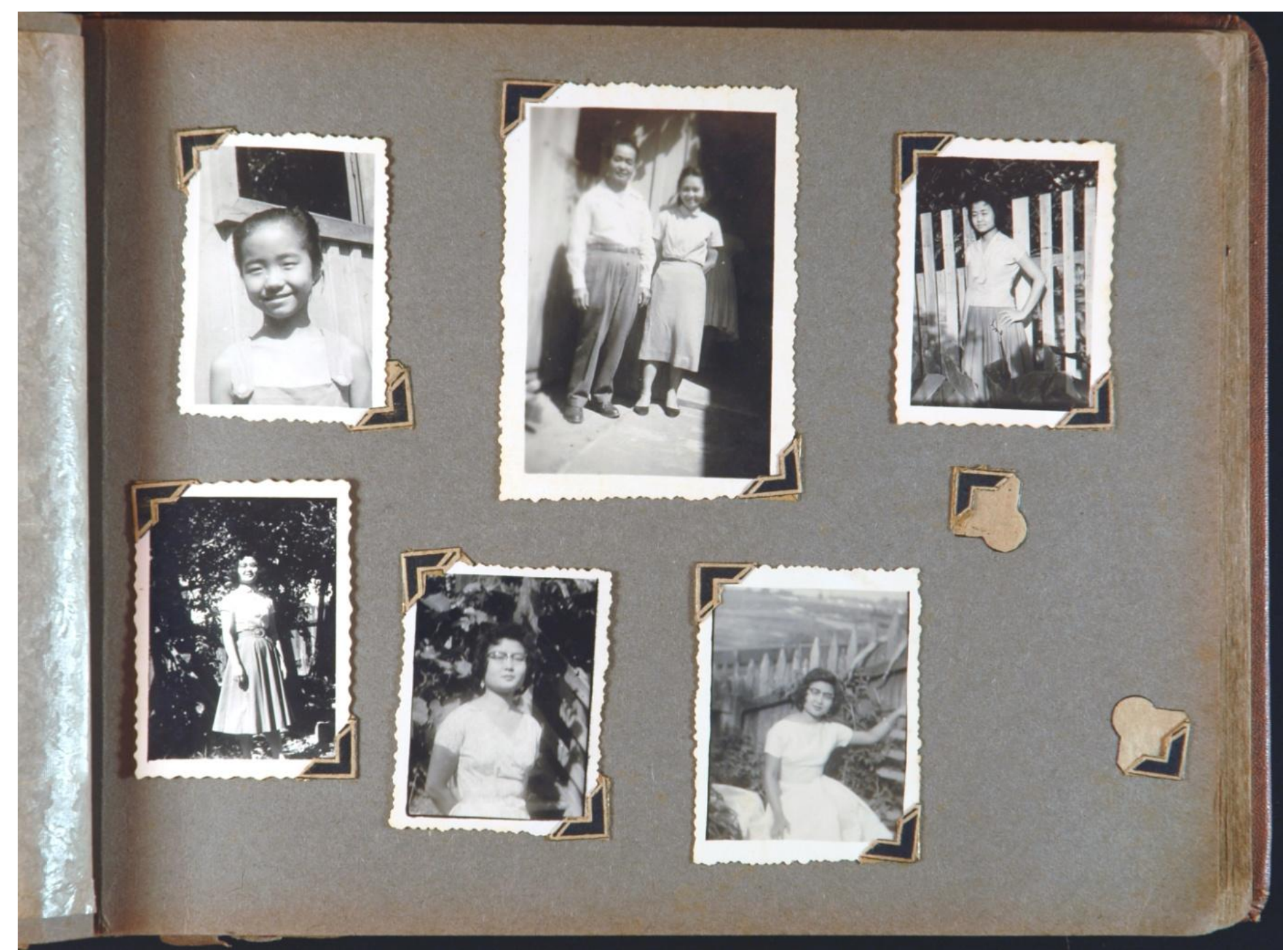

FIGURA 19. Décima quinta página do outro álbum da família Matsuyama 


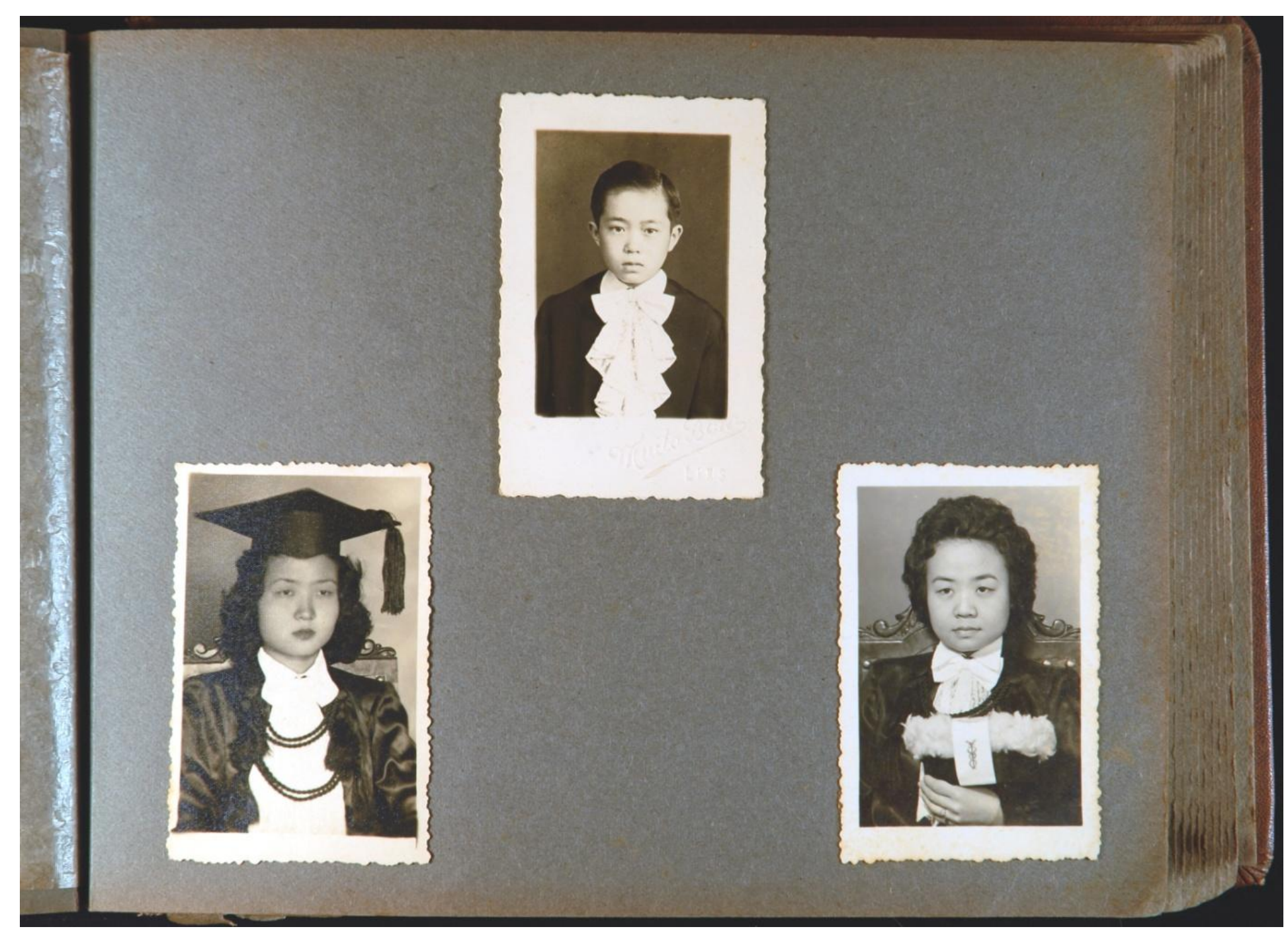

FIGURA 20. Vigésima nona página do outro álbum da família Matsuyama 


\section{3. Álbuns fotográficos}

Os álbuns de fotos de família possuem uma característica narrativa, que foi constatada por muitos pesquisadores, sob aspectos diversos. Há alguns pontos de concordância: o álbum é um artefato de memória e serve a propósitos de integração. "Um álbum de família reflete e expressa valores culturais, e ajuda a construir um sentimento de continuidade em face de dramáticas mudanças individuais, sociais e culturais." (CHALFEN, 1991, p. 115)

Martha Langford (2001) e Armando Silva (2008) concordam que os álbums são compilados com intenções discursivas e insistem em associações com a oralidade. O álbum conta a história da família por ser uma narrativa horizontal e estimula relatos passados de geração em geração. “Ao transcender a história oral, o álbum provê um foco visível para preservar e discutir a história particular do grupo que não poderia ser transmitida de nenhum outro modo.” (DENNETT, 1991, p. 73)

Assim como qualquer narrativa textual, a narrativa fotográfica expressa em álbuns se deve à contiguidade dos elementos. Foto após foto, página após página, as histórias familiares são encadeadas e sumarizadas em busca de unidade, familiar e icônica. No entanto, essa unidade é idealizada e a linearidade das narrativas nem sempre é almejada ou possível.

\footnotetext{
Através de fotografias, cada família constrói uma crônica-retrato de si mesma - um conjunto portátil de imagens que carrega o testemunho de sua união. Dificilmente importam as atividades que são fotografadas contanto que as fotografias sejam tiradas e estimadas. A fotografia torna-se um rito da vida familiar justamente no momento em que, nos países em processo de industrialização na Europa e na América, a própria instituição da família começa a sofrer uma cirurgia radical. Ao mesmo passo que essa unidade claustrofóbica, a família nuclear, estava sendo esculpida a partir de uma família agregada muito mais ampla, a fotografia surgia para celebrar, e reafirmar simbolicamente, a continuidade em perigo e a amplitude da vida familiar em desaparecimento. Esses traços espectrais, as fotografias, fornecem uma presença simbólica de parentes em dispersão. Um álbum de fotografias de família é, em geral, sobre a família estendida - e, frequentemente, é tudo o que resta dela. (SONTAG, 1990, p. 8-9)
} 
Desde o século XIX, a vida familiar foi objeto de deleite para as câmeras e seus amadores. Na compilação de registros fotográficos de Lady Hawarden, realizada por Virginia Dodier (1999), tanto momentos de intimidade quanto composições teatrais são exibidos, mesmo porque, ambos fazem parte da vida doméstica.

Diferentes artistas que empregam a fotografia em suas obras trabalharam com a ideia de foto de família e álbum fotográficos de muitos modos expressivos. Para citar apenas mais alguns, Harry Callahan (SZARKOWSKI, 1976), que fotografou sua esposa e filha, desde a gravidez. Sally Mann (1992), cuja obra inteira gira em torno da intimidade e da vida familiar. Ralph Eugene Meatyard (RHEM, 2002), que, com o provocativo álbum de família de Lucybelle Crater, aborda a artificialidade das relações humanas. Christian Boltanski, com L'Album de la famille D., realizado em 1971, interessado nas características repetitivas do álbum de família, pretende falar das questões mais universais a partir das coisas mais comuns. Nan Goldin (GOLDIN, ARMSTRONG, HOLZWARTH; 1996), que retrata exclusivamente sua família; no entanto, sua ideia de família não se baseia na consanguinidade, mas sim nas amizades e afinidades.

Os álbuns de família são particulares, idiossincráticos, não há como forjar uma regra geral de interpretação. Assim, procurar por uma metodologia seminal seria um equívoco, além de perda de tempo. As condições e motivos de seleção e montagem e as intenções comunicativas devem ser exploradas caso a caso; um sensato ponto em comum entre os diferentes pesquisadores.

A família Matsuyama possui dois álbuns fotográficos. Foram montados por Satiko, a segunda filha do casal, no começo da década de 1960. Todas as fotografias, nos dois álbuns, são em preto-e-branco. 
O álbum maior (34 x $25 \mathrm{~cm}$ ) possui fotos do círculo familiar e social, tanto imediato quanto distante, de Hideo e Akie (Figuras 1 a 16). Há fotos dos parentes de Hideo no Japão, assim como dos pais e irmãos de Akie.

O álbum compreende um intervalo de tempo de cerca de cinquenta anos, entre as décadas de 1910 e 1960. Apesar de não haver linearidade nesse desordenado álbum - não há sequência cronológica - a intenção de Satiko era organizar as relações de parentesco de seus pais, e de si mesma.

As fotos são trabalhos de profissionais contratados, seja em retratos de estúdio quanto de fotógrafos itinerantes. Há também fotos de produção caseira que se concentram na vida familiar mais próxima.

Nesse álbum, há uma concentração maior de fotos profissionais, que cobrem cerca de 21 páginas. As fotos caseiras compreendem onze páginas.

As dimensões das fotos realizadas por profissionais variam de 8,5 x 5,5 cm até $22 \mathrm{x}$ $16 \mathrm{~cm}$. As dimensões das fotos amadoras variam de 7 x $5 \mathrm{~cm}$ até 11 x $8 \mathrm{~cm}$. Por serem maiores, as fotos profissionais, na maioria dos casos, figuram sozinhas em suas páginas. Por outro lado, as fotos amadoras figuram junto a seus pares temáticos, em geral, fotos tiradas na mesma ocasião.

É possível notar uma semelhança entre os álbuns fotográficos e os métodos de diagramas genealógicos (BOUQUET, 2001, p. 105). Assim, por exemplo, fotos de pais e filhos são postas nas mesmas páginas (Figuras 3,6 e 7). Aparentemente, a desorganização do álbum fotográfico destoa da detalhada descrição genealógica. No entanto, a intenção de ambos é ser um auxílio visual para explicar as ramificações familiares.

Ao abrir a capa de imitação de couro, encontra-se, na contracapa, um retrato de Hideo quando jovem, realizado em estúdio profissional. Do lado esquerdo desse retrato, há 
uma 3 x 4 de Akie e, do direito, uma 3 x 4 de Hideo. Ambos tirados quando o casal já tem mais idade. Esse, então, é o eixo da narrativa do álbum, a vida de Hideo e Akie.

A primeira página (Figura 1) é composta por fotos recebidas do Japão da família Matsuyama, assim como as páginas segunda (Figura 2), décima nona (Figura 12) e vigésima primeira (Figura 14). Essas páginas pretendem fixar os laços entre as famílias no Japão e no Brasil e reafirmar as ligações simbólica e de fato, ao evidenciar que a família no Japão ainda constitui um importante grupo de referência para a família no Brasil.

Uma série de páginas alude à família estendida no Brasil. Dentre elas, destaco a página décima segunda (Figura 8), na qual aparece um retrato de Hideo com sua família adotiva para imigração, a família Otsuji, em Registro, em 1925. Mesmo após a imigração, a ligação formada entre eles continuou a ser significativa, a ponto de estar ilustrada nessa fotografia. Antes da imigração, havia uma relação, provavelmente de amizade, entre as famílias Matsuyama e Otsuji. Dessa forma, em algumas cartas, os parentes no Japão perguntam sobre a saúde da família Otsuji e enviam lembranças.

A relação entre as famílias Matsuyama e Sakasegawa era estreita, como se pode observar pelos retratos de família ao longo do álbum. Nas páginas décima sétima (Figura 11) e vigésima (Figura 13), constam dois retratos das famílias reunidas. Apesar dos laços serem ternos, pelo fato das famílias morarem em cidades diferentes do interior paulista, os encontros entre todos os membros das duas famílias eram esporádicos. O retrato da página décima sétima é de uma reunião das duas famílias em Guararapes, em 1933. A foto da página vigésima é uma reunião em torno do ano novo de 1940, em Machado de Melo. Esta última, por ocasião da publicação de um livro sobre a história do assentamento de pessoas provenientes de Kagoshima no Brasil (IKEDA, 1941, p. 252), deixou a esfera privada para adentrar um meio público pela primeira vez. Isso mostra o quanto essa imagem era significativa para os membros desse grupo familiar e o quanto eles se reconheciam nela, uma 
vez que a seleção dessa imagem para publicação foi feita pela própria família, muito provavelmente por Eiji Sakasegawa.

Membros da família Sakasegawa aparecem em diversas páginas do álbum, seja em retratos individuais ou em dupla, seja com seus cônjuges e filhos.

Em duas páginas, as fotos são arranjadas de uma maneira que remonta a esquemas genealógicos. Na página terceira (Figura 3), o retrato de casamento de Hideo e Akie figura no centro, e fotos $3 \times 4$ deles e dos filhos cercam os dois lados. Na página décima primeira (Figura 7), as fotos 3 x 4 de Eiji e Ine estão centralizados no topo e retratos feitos por profissionais dos filhos homens seguem abaixo. Na nona página (Figura 6), logo abaixo do retrato de Ine, encontram-se retratos de suas filhas.

Além do casamento de Hideo e Akie na página terceira, os casamentos dos irmãos de Akie figuram nas páginas quarta (o irmão Matsuo e sua esposa Kimiko, em 1950; Figura 4) e oitava (a irmã Tomiko e seu marido Nakagama, em 21 de abril de 1951). Laços matrimoniais são também o tema da confraternização ilustrada na página vigésima sexta com um retrato de grupo das famílias Sakasegawa, Matsuyama e Minami por ocasião das bodas da irmã de Akie, Hamako com Hisao Minami.

O casamento é um tema querido pela família pois é através desse laço que o futuro da família começa a se esboçar. Nessa linha de pensamento, os filhos são a realização da continuação da família. Assim, os bebês e as crianças preenchem diversas páginas do álbum, tanto com fotos amadoras quanto com fotos realizadas em estúdios profissionais (Figuras 5, 9, 10, 12, 14 e 15). Se os antepassados recebem um cuidado reverente, os descendentes despertam uma dedicação jubilosa com a ideia de que a família vai continuar a existir e se perpetuar.

A escola, portanto, é uma preocupação pungente, pois, para os imigrantes, ela representa a possibilidade de ascensão social, exercício da cidadania e, enfim, um futuro mais 
confortável para os filhos e netos. Assim, duas páginas do álbum são dedicadas a esse tema. A trigésima página (Figura 16) comporta duas fotos, uma foto caseira de Deicy à caminho da escola, em 1941, e um retrato do grupo escolar de Deicy feito por um profissional contratado, em Avanhandava, no mesmo ano. Esse retrato confirma que Deicy cursou a escola brasileira e que a classe era mista (meninos e meninas). Na trigésima segunda página, há um retrato feito por um profissional contratado do grupo escolar de Satiko, em Lins. Do mesmo modo, Satiko cursou a escola brasileira em classe mista.

Zeila de Brito Fabri Demartini (2000) discute vários tópicos sobre a educação dos imigrantes japoneses e seus filhos de forma muito interessante. Aqui, basta apenas constatar que os filhos do casal Matsuyama cursaram apenas a escola normativa brasileira, fato que parece ter contribuído para sua adaptação ao dar menor importância à língua e etiqueta japonesas. Tomo como exemplo o fato de Satiko ter enveredado pelo magistério, chegando a se aposentar como diretora de uma escola primária da rede estadual paulistana.

Apesar de Richard Chalfen (1991) atentar para as fotos em álbuns de imigrantes japoneses que se referem ao trabalho, há apenas uma foto de tal espécie nesse álbum fotográfico. É uma foto amadora da família Sakasegawa, em Cotia, trabalhando em sua plantação de tomate. As netas de Ine, Satiko e Neli, se recordam de como a avó tinha um cuidado especial com essa parte da plantação, ao não utilizar agrotóxicos.

Nas fotos realizadas por profissionais, tanto em estúdios quanto em lugares familiares (retratos realizados por fotógrafos itinerantes), as poses são rígidas, os corpos se mostram pouco à vontade. Os agrupamentos procuram evidenciar a integridade da família.

Nas fotos caseiras, feitas com a câmera da família, as pessoas estão, obviamente, mais relaxadas, em poses mais confortáveis. Aqui, não há necessidade de todos estarem sempre juntos nas mesmas fotos. Os agrupamentos são menos formais, parece haver um jogo doméstico entre retratados e fotógrafos amadores. Por exemplo, formar uma fila com os 
filhos, em uma ponta, o mais velho, na outra, o mais novo (Figura 10). As fotos caseiras dão a impressão de que quase podemos ouvir o pai dizendo às crianças o que fazer, onde se colocar e de que modo. No momento em que a película recebe a imagem latente, trata-se muito mais de uma brincadeira familiar do que um registro para a história. Existe, aqui, uma intimidade entre sujeito e objeto fotográfico que, no estúdio profissional, é praticamente impossível.

André Rouillé concorda com esse ponto de vista e observa em relação às fotografias de família:

Seu dialogismo fundamental repousa principalmente sobre essa posição original em que o operador fica o mais próximo possível de seus modelos, no mesmo espaço que eles, no fato de ser ele mesmo uma parte envolvida nas cenas retratadas. Ele é, além disso, ao mesmo tempo produtor e destinatário de suas fotos. (ROUILÉE, 2005, p. 240)

A última página a conter fotos no álbum possui três retratos amadores, caseiros, ou ainda, vernaculares. Foram tirados na casa em Lins, no final da década de 1950. São eles: um retrato de Akie, um de Luci e o outro, das três irmãs mais velhas, Deicy, Satiko e Luci. Ainda nessa página, restaram cantoneiras vazias, delimitando o espaço para duas outras fotografias. Satiko, em entrevista não estruturada, com fotos, não conseguiu se lembrar se havia fotografias nessas cantoneiras e se elas foram tiradas, ou, enfim, o que aconteceu.

As lacunas nas páginas desse álbum só começam a aparecer na décima terceira página (Figura 9). Assim, nesta, há um vazio que, pela lógica, deveria conter um retrato feito em estúdio profissional de Satiko enquanto criança. Isso porque as outras fotos da página são retratos de Deicy e Milton, quando infantes, feitos em estúdios. Ou seja, o tema dessa página são os filhos mais velhos do casal Matsuyama. À semelhança da sétima página do álbum (Figura 5). Falta, então, o retrato de Satiko ou de Luci... 
Na décima quinta página (Figura 10), que ilustra as crianças em cenas da vida doméstica, também há um espaço vazio de uma foto. Por similaridade, a foto perdida devia ser de mesmo teor das que permaneceram.

A vigésima primeira página (Figura 14) exibe fotos recebidas da família Matsuyama do Japão. Restaram três retratos dos pais, irmãos e sobrinhos de Hideo. Faltam três imagens, como as cantoneiras deixam perceber. Do mesmo modo, por similaridade, as fotos que faltam também deveriam ser de parentes no Japão.

Esses são apenas alguns exemplos, ainda existem dez lacunas ou dez fotos que foram perdidas ou se desprenderam de cinco páginas. Apesar de se poder inferir, por similaridade, o que os espaços vazios ilustravam, as lacunas no álbum fotográfico, uma vez que acontecem, são impossíveis de serem restauradas. Do mesmo modo, a memória de Satiko, que foi quem montou esse álbum, não pôde recuperar o que se perdeu.

Em seguida, o álbum ainda possui várias páginas, mas que foram deixadas em branco, sem fotos. Isso é um pouco intrigante, afinal, pela abundância de fotografias, o álbum poderia ter continuado. Talvez o tédio advindo da repetição tenha, aos poucos, deixado o hábito de preencher as páginas cair no abandono.

Para resumir, das cento e dez fotos contidas no álbum, quarenta e uma são retratos de crianças, tanto filhos quanto sobrinhos do casal Matsuyama, vinte e nove são retratos individuais de diferentes membros da família, tanto imediata quanto estendida, vinte e dois são retratos de família e dois são retratos de casais. Os retratos de duplas podem ser divididos em retratos de irmãs (quatro), de avô e neto ou neta (dois), de mãe e filha (dois) e de pai e filhos (um). Os retratos de casamento podem ser divididos em retratos dos noivos (três) e retrato de grupo (um). Os retratos escolares podem ser divididos em retratos de grupo (dois) e retrato individual (um). 
Com o intuito de averiguar com qual intenção esse álbum foi montado, fiz uma entrevista não estruturada, com fotos, gravada em meios audiovisuais, com Satiko, que foi quem o montou. Na ocasião, minha intenção era confirmar, ou não, a vontade dos filhos de imigrantes em preservar as relações de parentesco e amizade através da narrativa fotográfica fiada em álbuns. Em um estudo similar, Richard Chalfen (1991) informa que a principal razão para a organização de fotos em álbuns é a necessidade de figurar e fixar em álbuns essas relações afetivas. Apesar de Satiko ter revelado que sua intenção era de fato manter os laços de família e amigos, o álbum era pouco conhecido pela família. Os filhos do casal Hideo e Akie, irmãos de Satiko, conheciam as fotografias contidas no álbum, mas reuniões de família para reavivar as memórias eram incomuns, senão inexistentes. Já os netos de Hideo e Akie, filhos dos irmãos de Satiko, não tinham nenhum conhecimento tanto das fotos quanto do álbum em si. Eu mesmo, com meu evidente interesse pela história da fotografia, só fui ver o álbum quando minha avó, Akie, estava bem doente.

Satiko forneceu a informação de que, após a morte de Hideo, Akie gostava de folhear o álbum ocasionalmente. Nesses momentos íntimos, as memórias do marido e de outros entes queridos, já falecidos, podiam ser trazidas à tona, com carinho e saudades.

A característica de resguardo dos imigrantes japoneses e seus descendentes foi então constatada no fato de que a fruição do álbum por Akie era feita em momentos de solidão e introspecção. Tanto Sylvia Junko Yanagisako (1985) quanto Akemi Kikumura (1991) notam em seus diferentes estudos sobre a adaptação de imigrantes japoneses na América que mesmo entre parentes próximos (mãe e filha, por exemplo) alguns sentimentos, pensamentos e memórias são privados e incomunicáveis.

Por sua vez, o álbum menor $(28 \times 20 \mathrm{~cm})$ foi feito com fotos de poucos rolos de negativo, que datam o final da década de 1950 e o começo de 1960 (Figuras 17 a 20). Praticamente todas as fotografias são de produção caseira; a maioria foi realizada na casa em 
Lins e algumas foram feitas em São Paulo. As poucas fotos feitas por profissionais são dez retratos 3 x 4 dos filhos do casal, um retrato de primeira comunhão do filho mais novo, Luiz Masao, de 1964, e três retratos de formatura colegial dos filhos mais velhos, Satiko, Milton e Luci (Figura 20).

As dimensões das fotos neste álbum não variam tanto quanto no outro: de 4 x $5 \mathrm{~cm}$ até 9 x 6,5 cm, com predomínio de fotos com dimensões 4 x $5 \mathrm{~cm}$ e 8 x $5 \mathrm{~cm}$. A única exceção é a foto realizada por profissional na ocasião da primeira comunhão de Luiz, 12 x 8 $\mathrm{cm}$.

Este álbum se refere à família nuclear, ou seja, pais e filhos, com exceção de um único retrato de Akie e sua irmã Hamako. A maioria das fotos são retratos individuais dos filhos do casal Matsuyama. Os demais retratos são combinações de dois, três ou cinco irmãos, mãe e filhos (um ou dois), do casal e do casal com o filho mais novo. No entanto, não há um retrato de grupo no qual figurem todos os membros da família (pai, mãe e os seis filhos). O mais próximo disso é um retrato do casal com cinco filhos. A ausência do filho mais velho, Milton, nesse retrato se deve ao fato dele ter saído de casa para trabalhar em São Paulo. Uma página nesse álbum é dedicada a ele (Figura 18), com cinco fotos que ele enviou de si, passeando pelo centro da cidade, e o retrato de formatura, que também aparece na vigésima nona página (Figura 20).

Esse álbum mostra os filhos do casal Matsuyama em sua juventude. Alguns retratos dos filhos mais novos foram tirados quando eles eram crianças. Em outros retratos, esses filhos mais novos já aparecem na puberdade e mocidade. Os filhos mais velhos são mostrados em seus primeiros passos na idade adulta, mas ainda jovens. Uma única exceção é um retrato de Satiko quando bebê.

O álbum foi montado pouco tempo após a mudança para São Paulo (década de 1960), e reflete essa ruptura, ou tentativa de união, entre a família e a casa em Lins e a da 
capital. Também existem diversas lacunas ao longo das páginas desse álbum (Figura 19).

Pode-se imaginar que as fotos que foram retiradas das páginas possuem similaridades com as que permaneceram. Mas não há como dizer o que houve de fato.

O primeiro álbum descrito mais acima, álbum 1, foi montado antes do álbum de scrito logo acima, álbum 2; contêm fotos mais antigas também.

O álbum 1 é um pouco mais atemporal, mesmo porque cobre cinquenta anos. As relações remetem ao passado, mesmo no momento de montagem (década de 1960). O álbum 2, nesse sentido, seria mais atual. Desse modo, parece haver uma progressão narrativa da família estendida para a família nuclear. Naturalmente, pela distância em relação à família estendida, a família nuclear torna-se imediatamente mais importante.

Talvez uma intenção de montagem dos álbuns tenha sido a de relatar em imagens tudo o que havia transcorrido com a família Matsuyama até aquele momento (1960). Assim, no primeiro álbum, são narradas as relações com os parentes no Japão e com os parentes no Brasil, a formação da família nuclear, o nascimento dos filhos, etc. No primeiro álbum, por exemplo, é mais comum encontrar fotografias dos filhos do casal Matsuyama em tenra idade. Nas últimas páginas desse álbum, pode-se vê-los com mais idade, na juventude. O segundo álbum mostra a família em seu lar em Lins, antes da mudança para a capital. Esse passado recente em 1960, a mudança para São Paulo e a nova casa, parece ser o tema desse álbum.

Os álbuns de fotografias são especialmente caros aos imigrantes, pois tornam possível o sentimento de continuidade e união familiar, apesar da experiência de um processo dispersivo como a migração.

As fotografias são, pois, um recurso eminentemente moderno que possibilita a conservação e permanência de uma continuidade visual do passado familiar. Resistindo à aceleração do tempo, elas proporcionam uma orientação para a memória num contexto que tende a ser fragmentário e dispersivo. Por meio de poses e instantâneos que contribuem para a fixação da auto-imagem de indivíduos e grupos familiares, vamos acompanhar os registros de alguns ritos da vida privada e de alguns padrões de sociabilidade. (SCHAPOCHNIK, 1998, p. 457) 
Os álbuns fotográficos são uma importante parte da memória familiar. Eles narram os momentos mais significativos da história de uma família, segundo Pierre Bourdieu (1965), tais como batismos, aniversários, primeiras comunhões, casamentos, nascimentos, etc. Uma vez que o esquecimento é intrínseco à memória, ele também se manifesta em álbuns de fotografias, de forma visual: lacunas ou espaços em branco. É extremamente comum encontrar páginas onde não há fotos, páginas de onde as fotos foram retiradas, restando apenas cantoneiras ou legendas, quando muito. William James Booth discute diferentes tipos de esquecimento:

\footnotetext{
Alguns são o resultado de uma erosão quase natural, como se a passagem do tempo apagasse os traços do passado, deixando apenas uma indentação em seu lugar. Outros são muito mais deliberados e motivados, como quando a memória é silenciada devido a interesses, medo ou vergonha. (BOOTH, 2006, p. 75)
}

Em álbuns fotográficos de famílias, ambos os casos podem acontecer. No primeiro, a erosão pode ocorrer quando a cola perde o efeito, então, a foto pode ficar pendurada na página ou se perder. A segunda é bem comum e pode acontecer da seguinte maneira: um parente que não tem fotos de seus pais ou parentes pode pedir ao dono do álbum por aquela imagem onde seus entes queridos aparecem. Às vezes, o dono concorda e descola a foto do álbum, o que resulta em uma lacuna na narrativa do álbum que, provavelmente, jamais poderá ser restaurada. Aqui, então, as motivações são os desejos do coração e a vontade de rememorar seres queridos. 


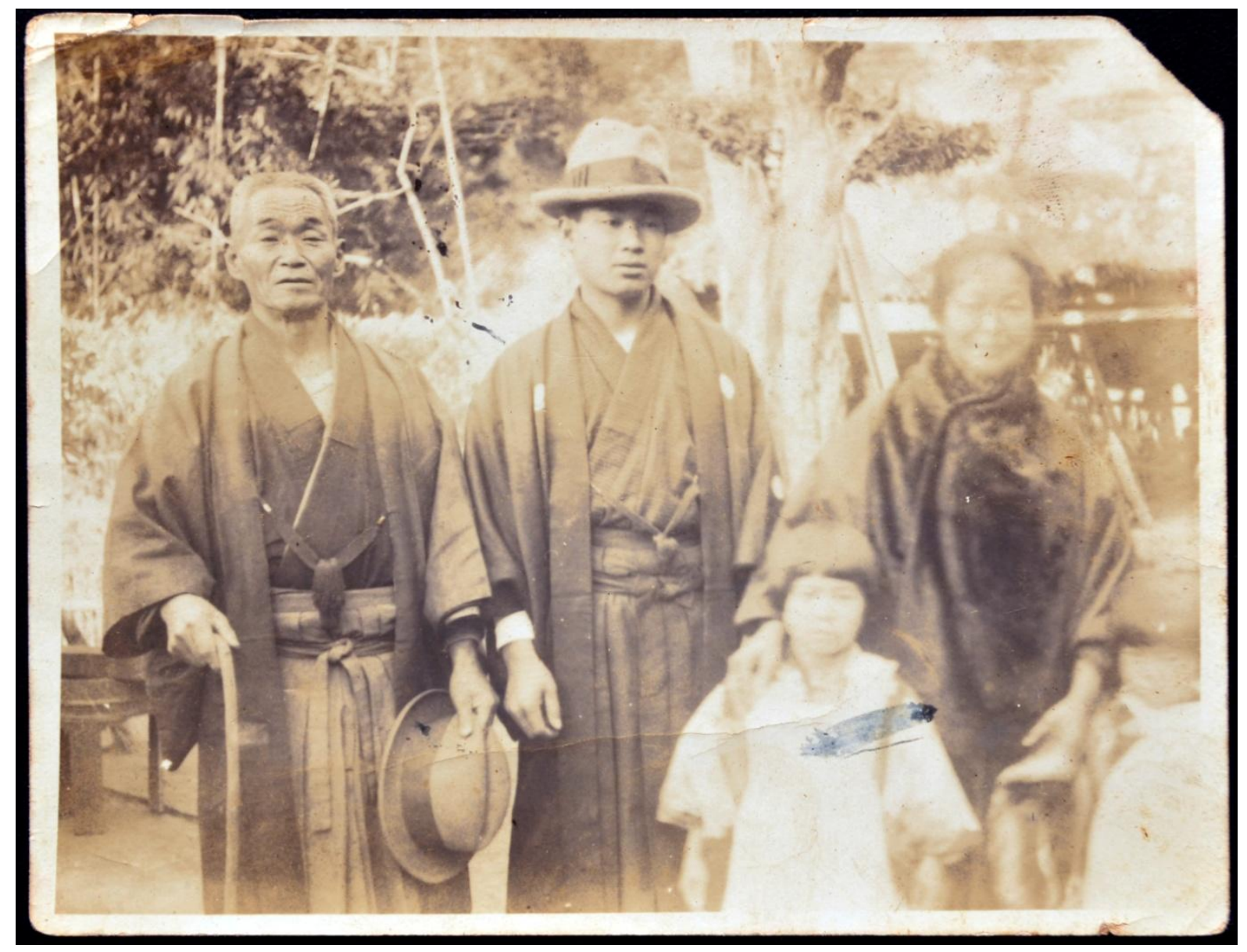

FIGURA 21. Família Matsuyama. Kagoshima, Japão. ca. 1930 


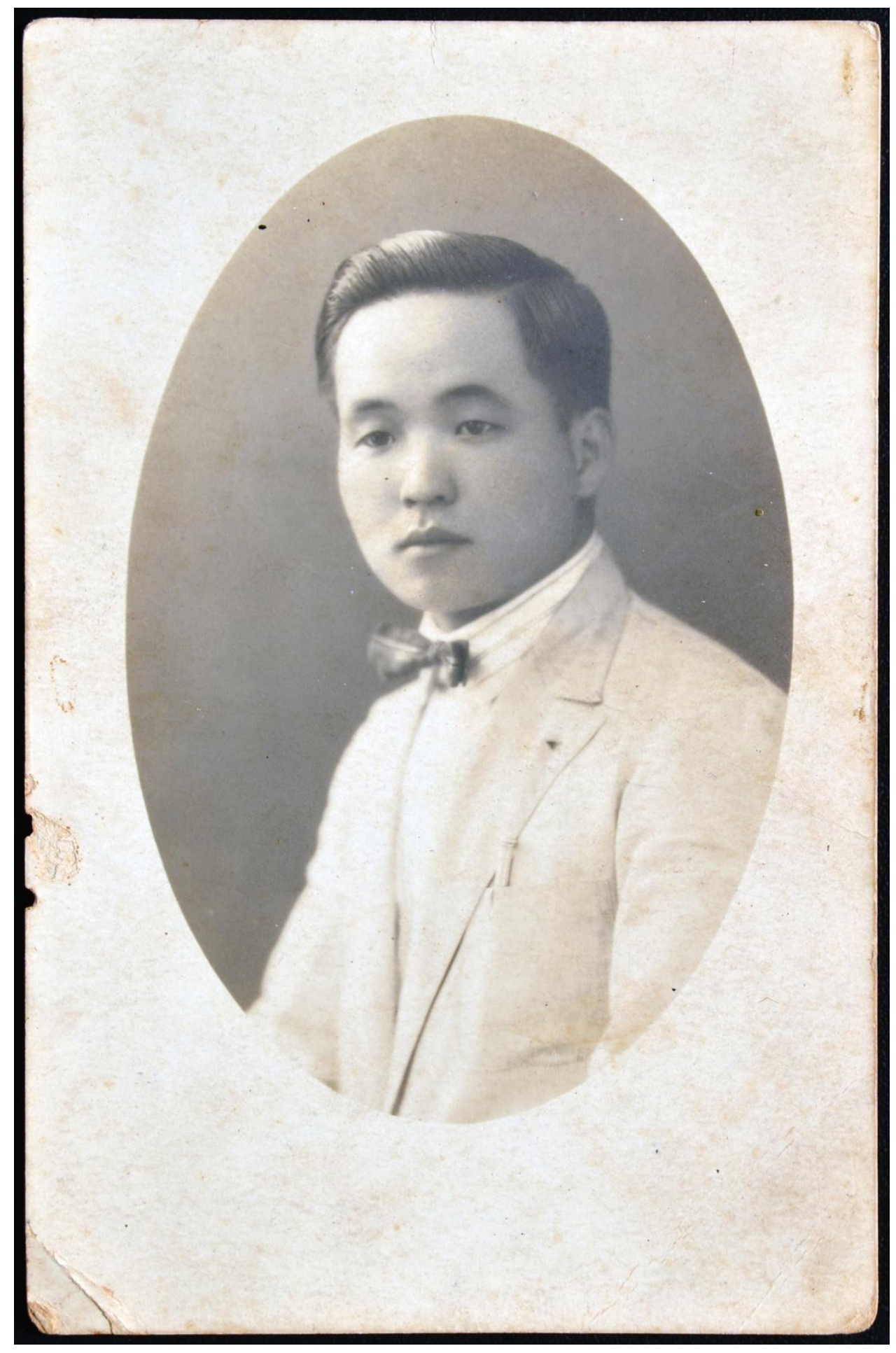

FIGURA 22. Hideo Matsuyama. Santos, SP. ca. 1920 


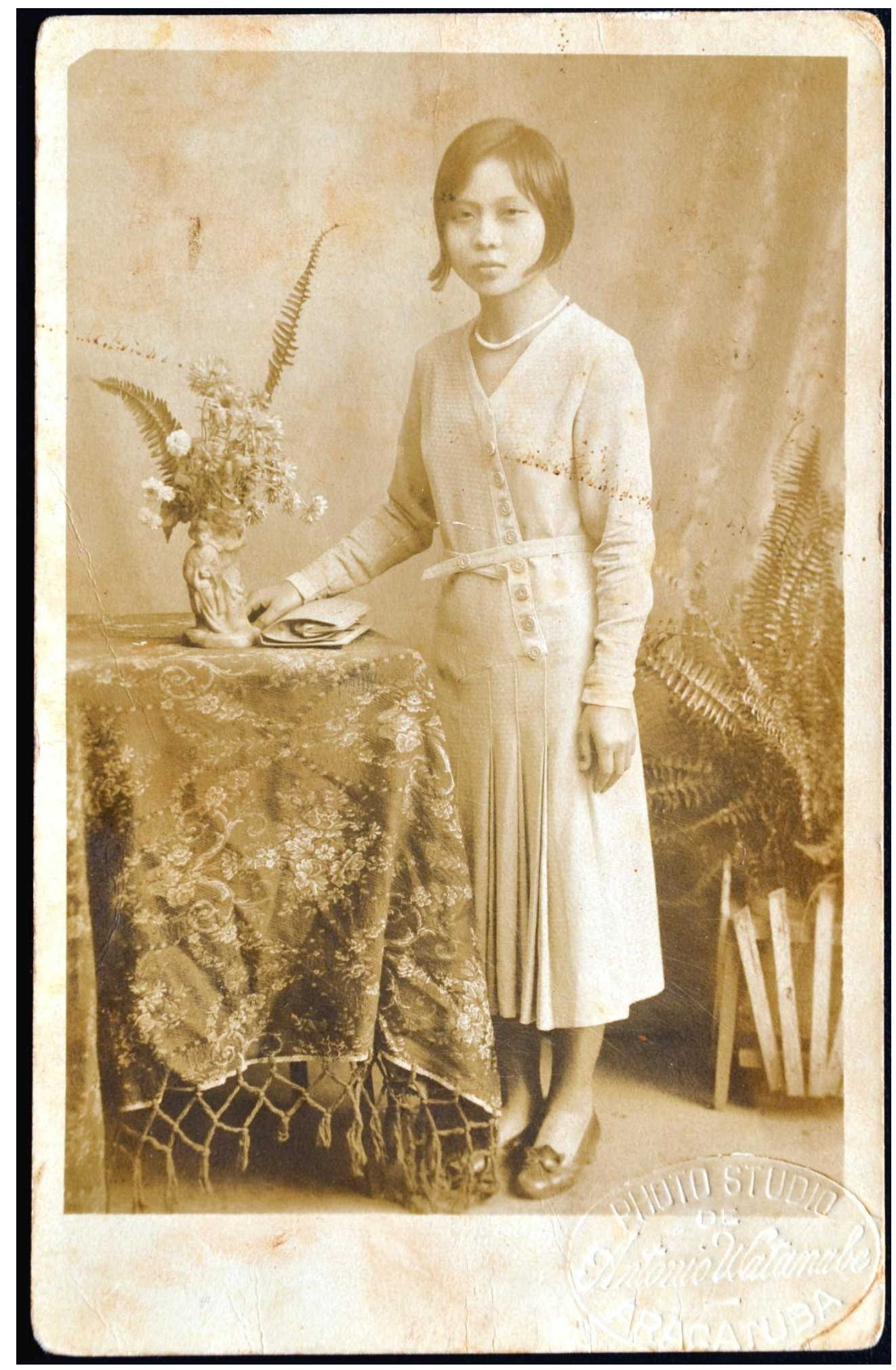

FIGURA 23. Akie Matsuyama - foto de casamento. Araçatuba, SP. 1932 


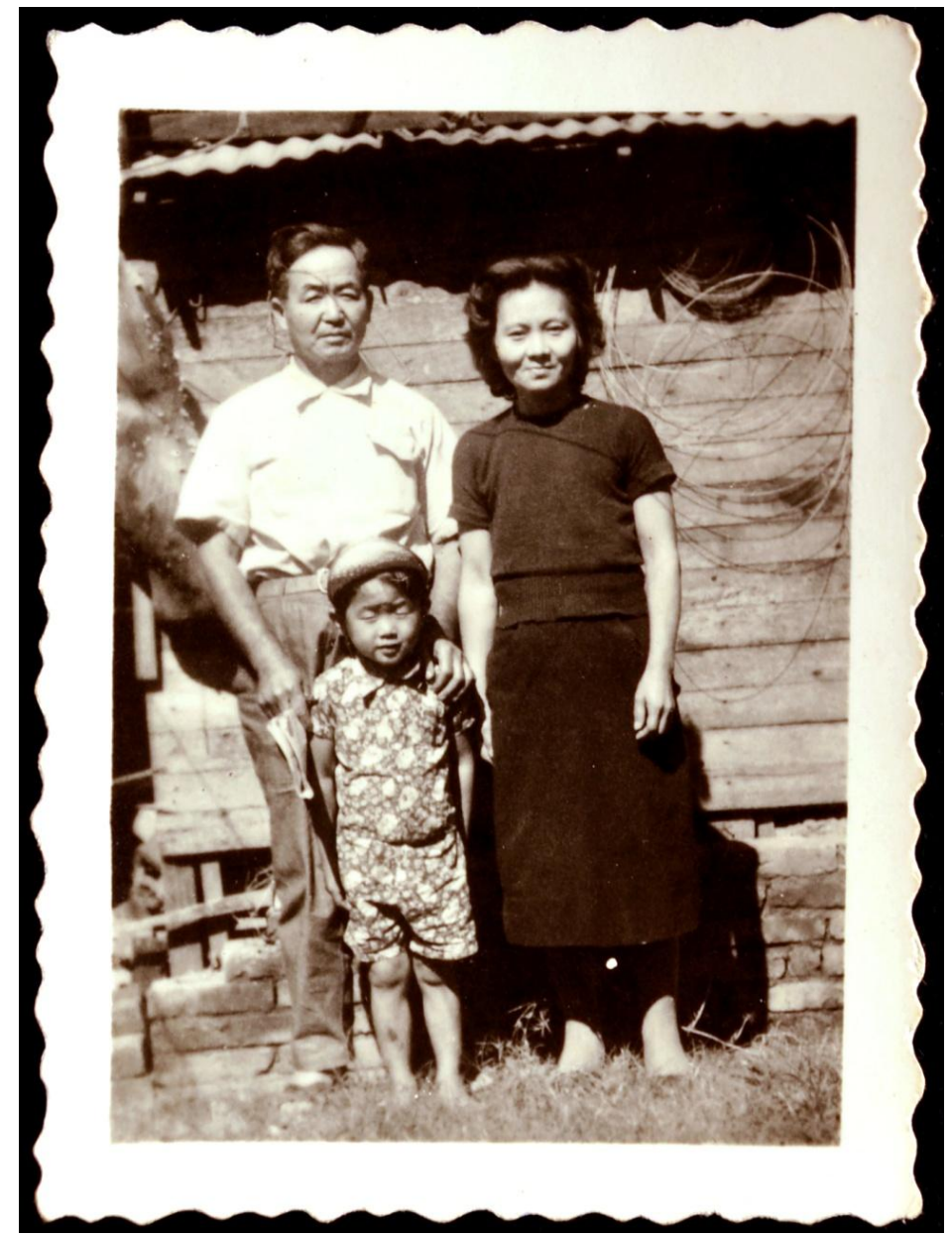

FIGURA 24. Hideo, Akie e Luiz Masao Matsuyama. Lins, SP. 1956 


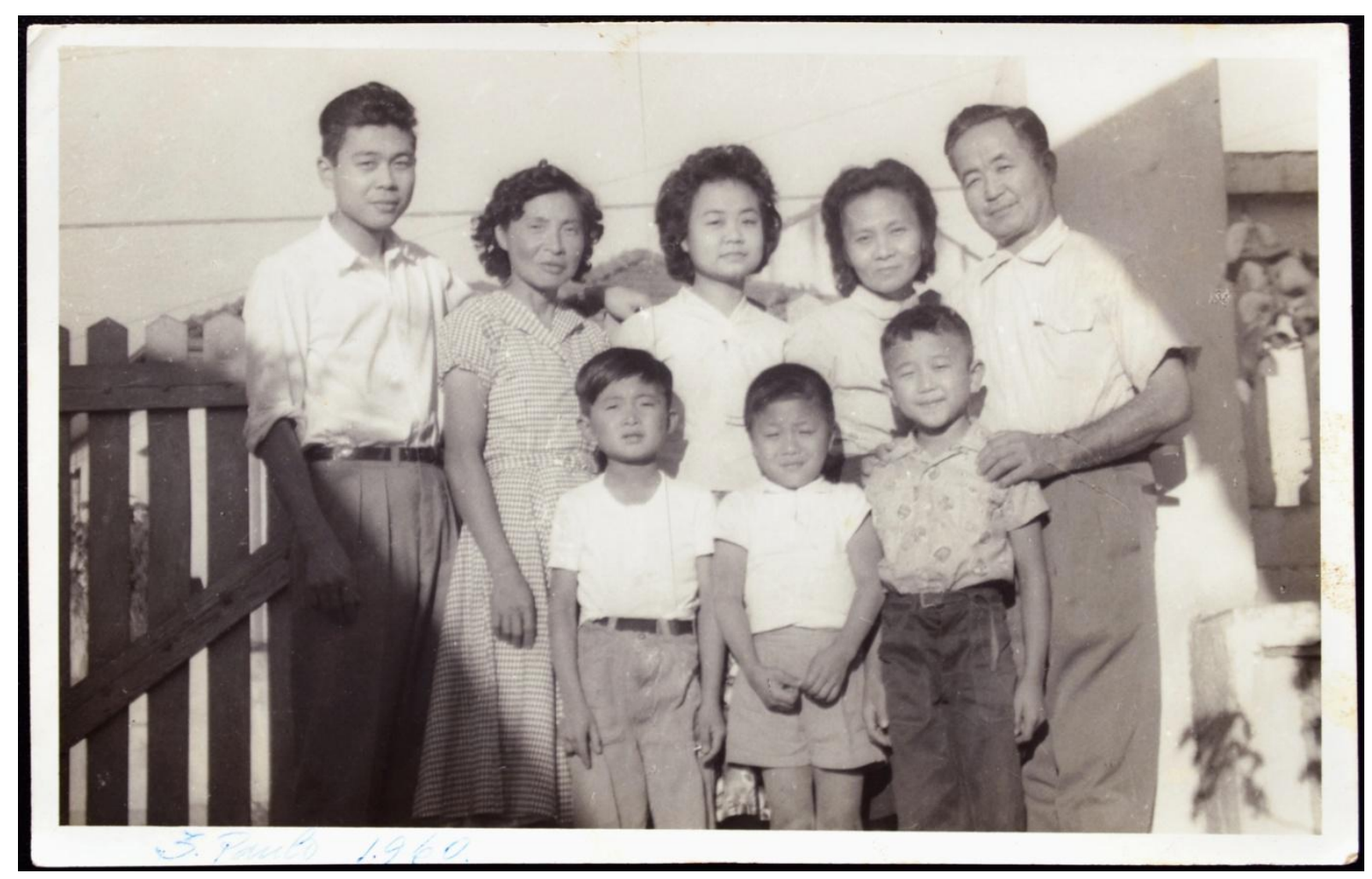

FIGURA 25. Família Matsuyama. São Paulo, SP. 1960 


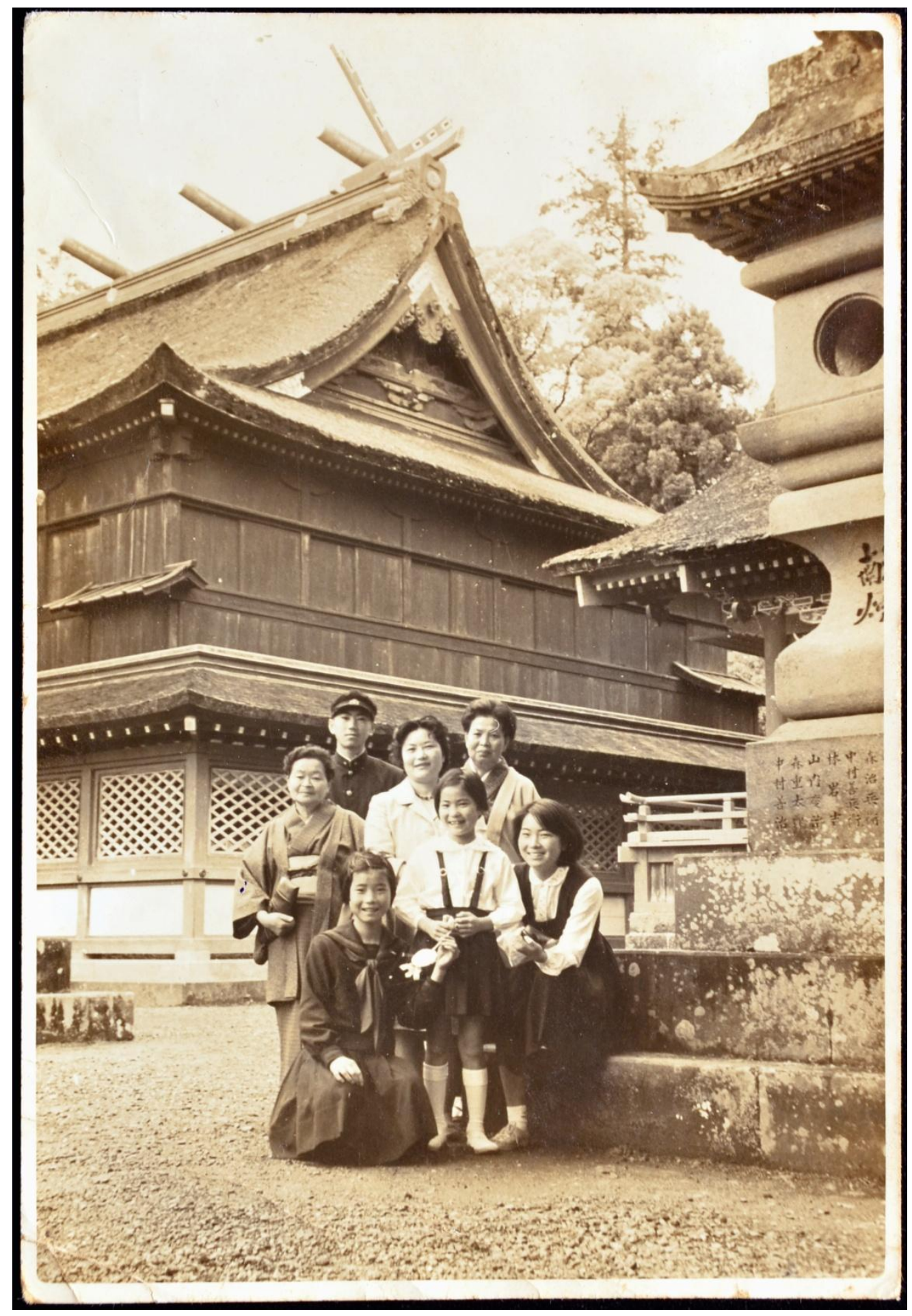

FIGURA 26. Família Matsuyama. Kagoshima, Japão. ca. 1950 


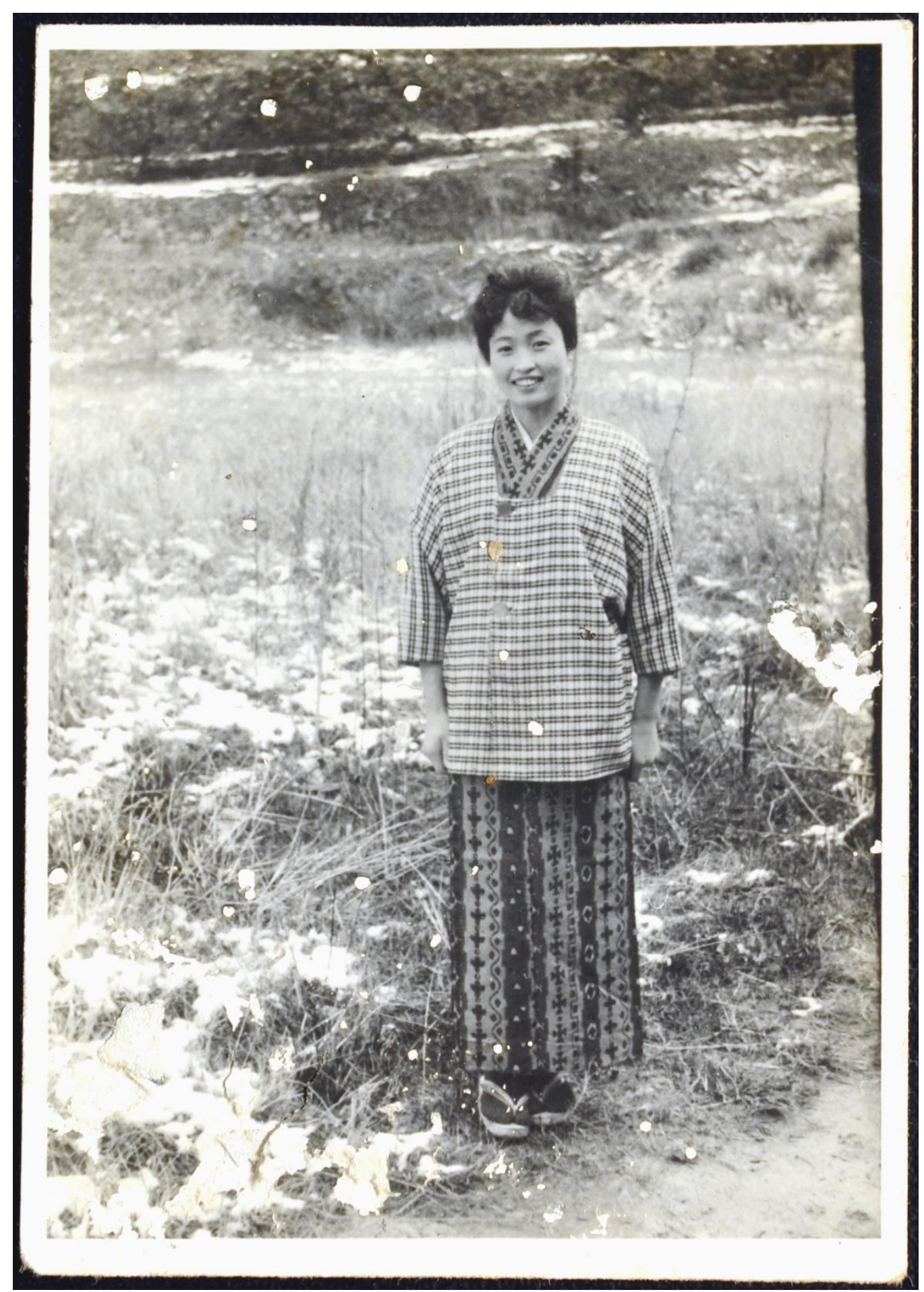

FIGURA 27. Ichiko Matsuyama. Kumamoto, Japão. ca. 1960 


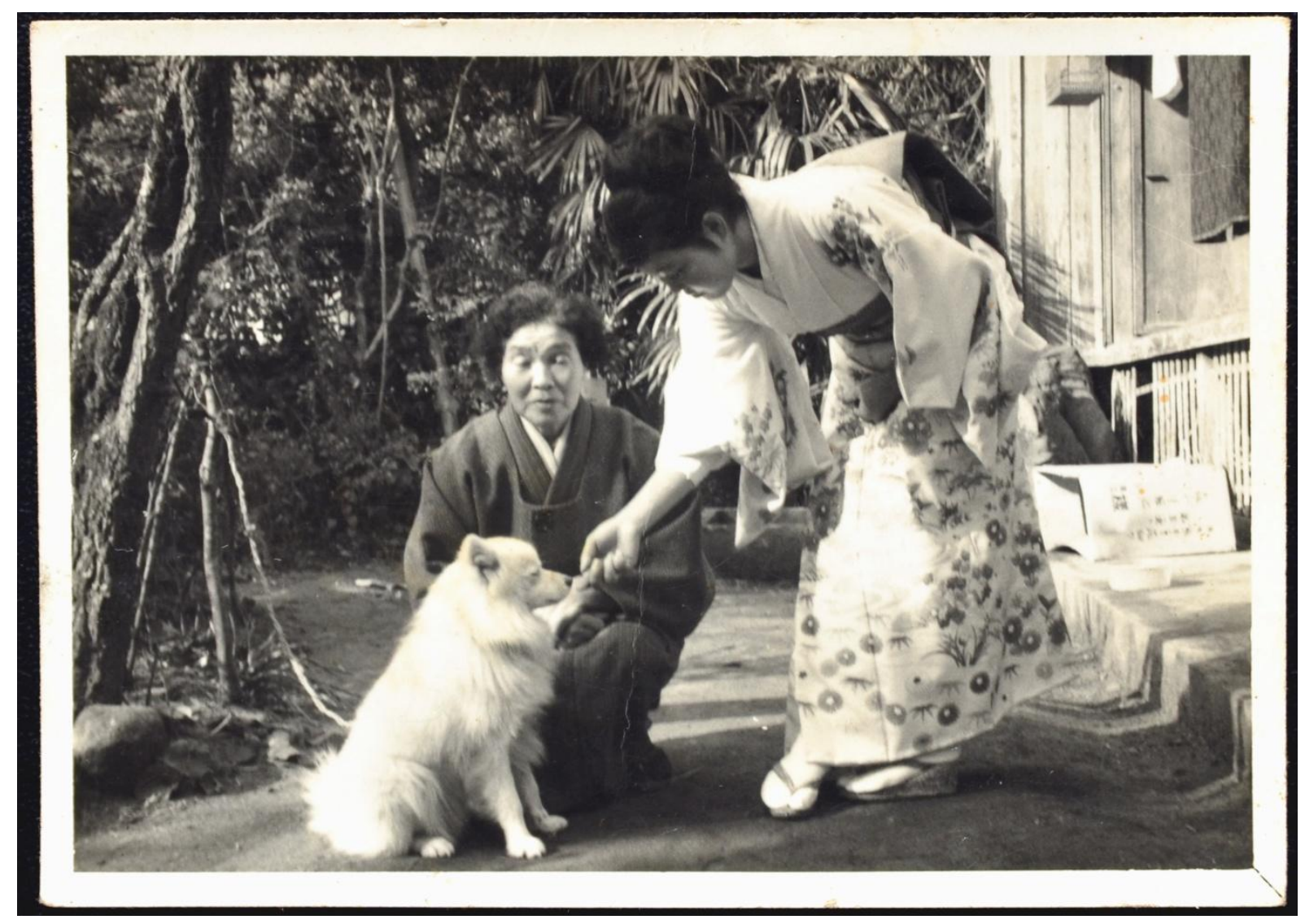

FIGURA 28. Família Matsuyama. Kagoshima, Japão. 1965 


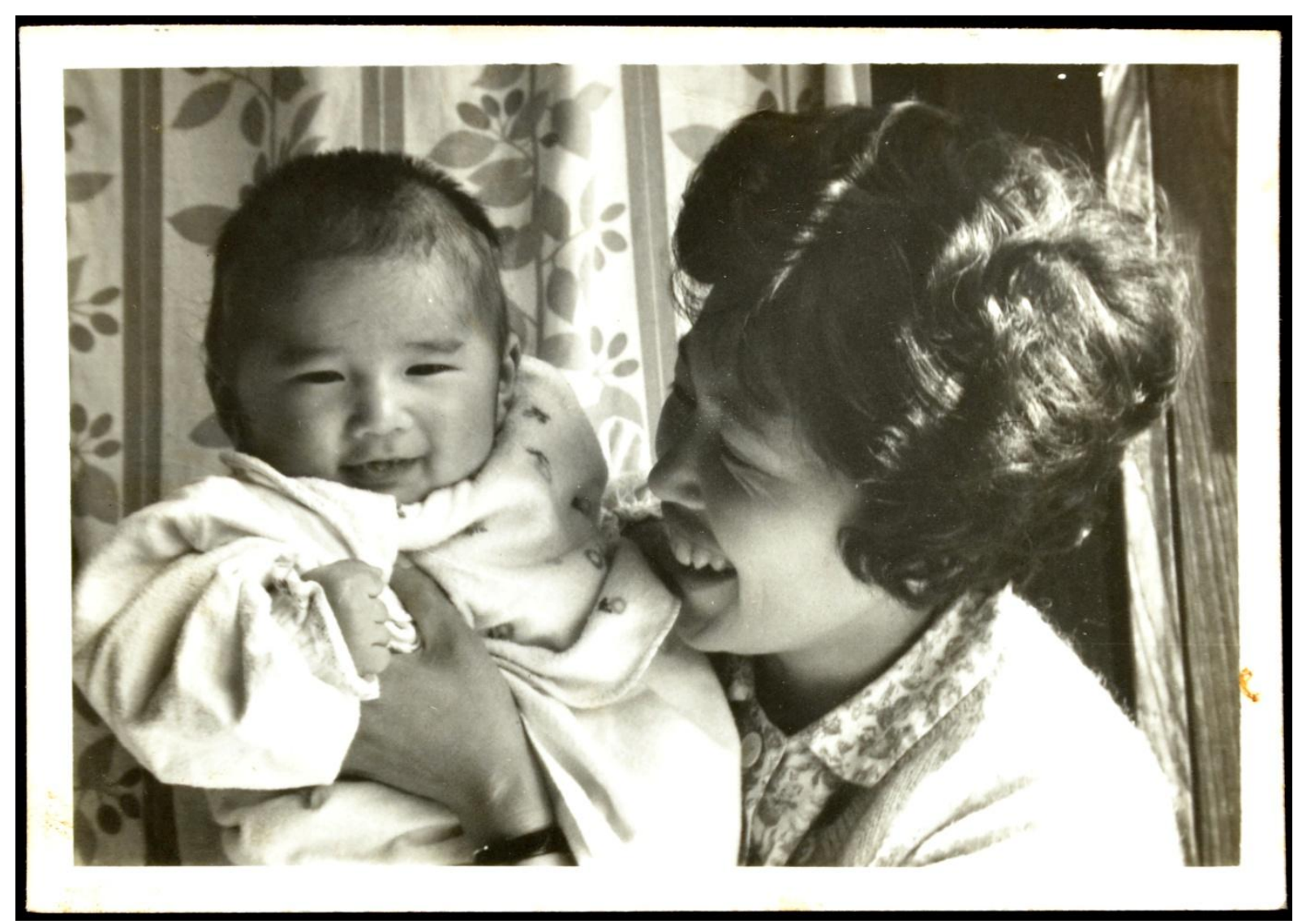

FIGURA 29. Makoto e Fuyoko Shinmyozu. Kagoshima, Japão. 1964 


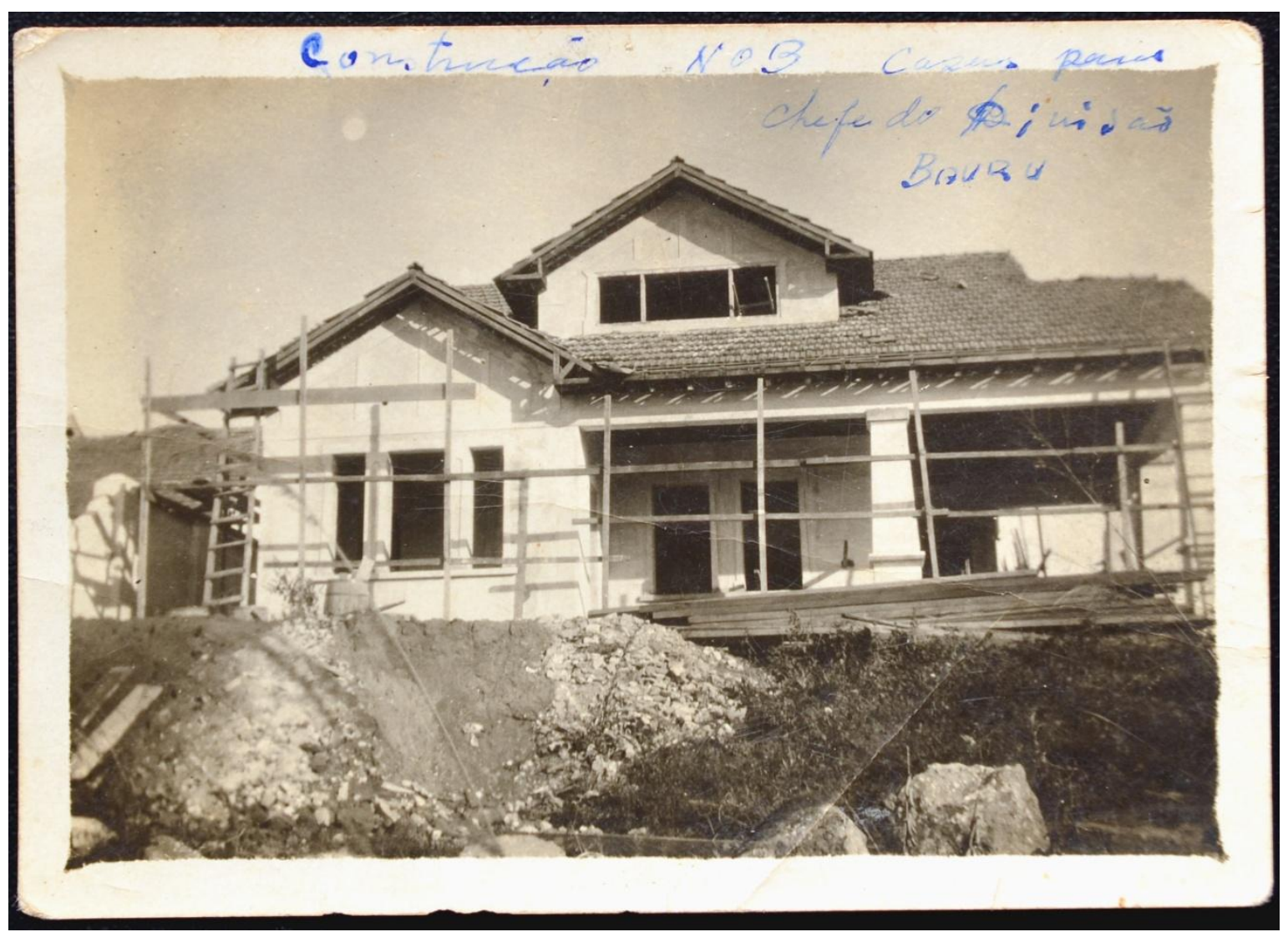

FIGURA 30. Fotografia de Hideo Matsuyama. Bauru, SP. ca. 1940 


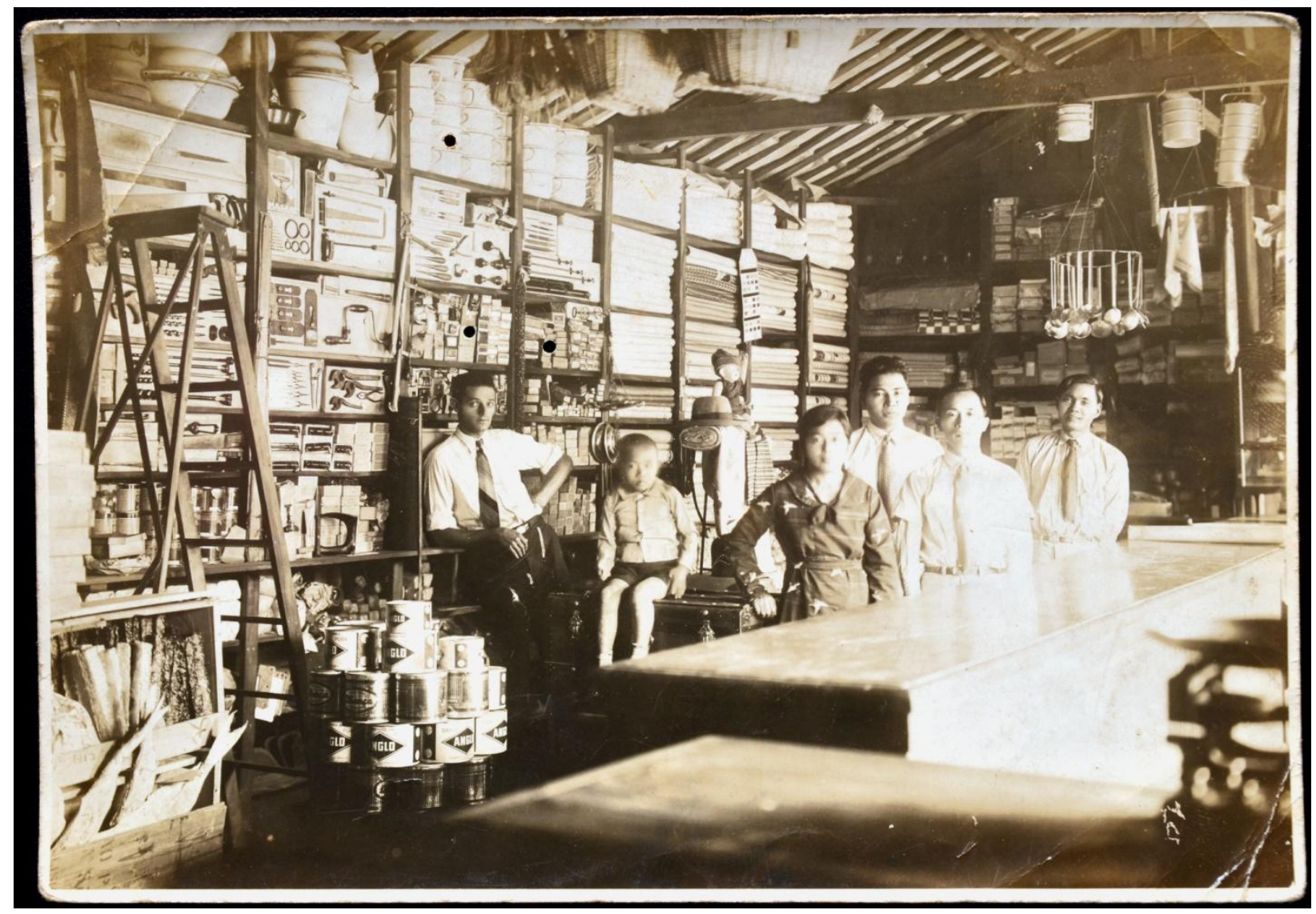

FIGURA 31. Armazém de secos e molhados dos irmãos Ohara. Mirandópolis, SP. 1934 


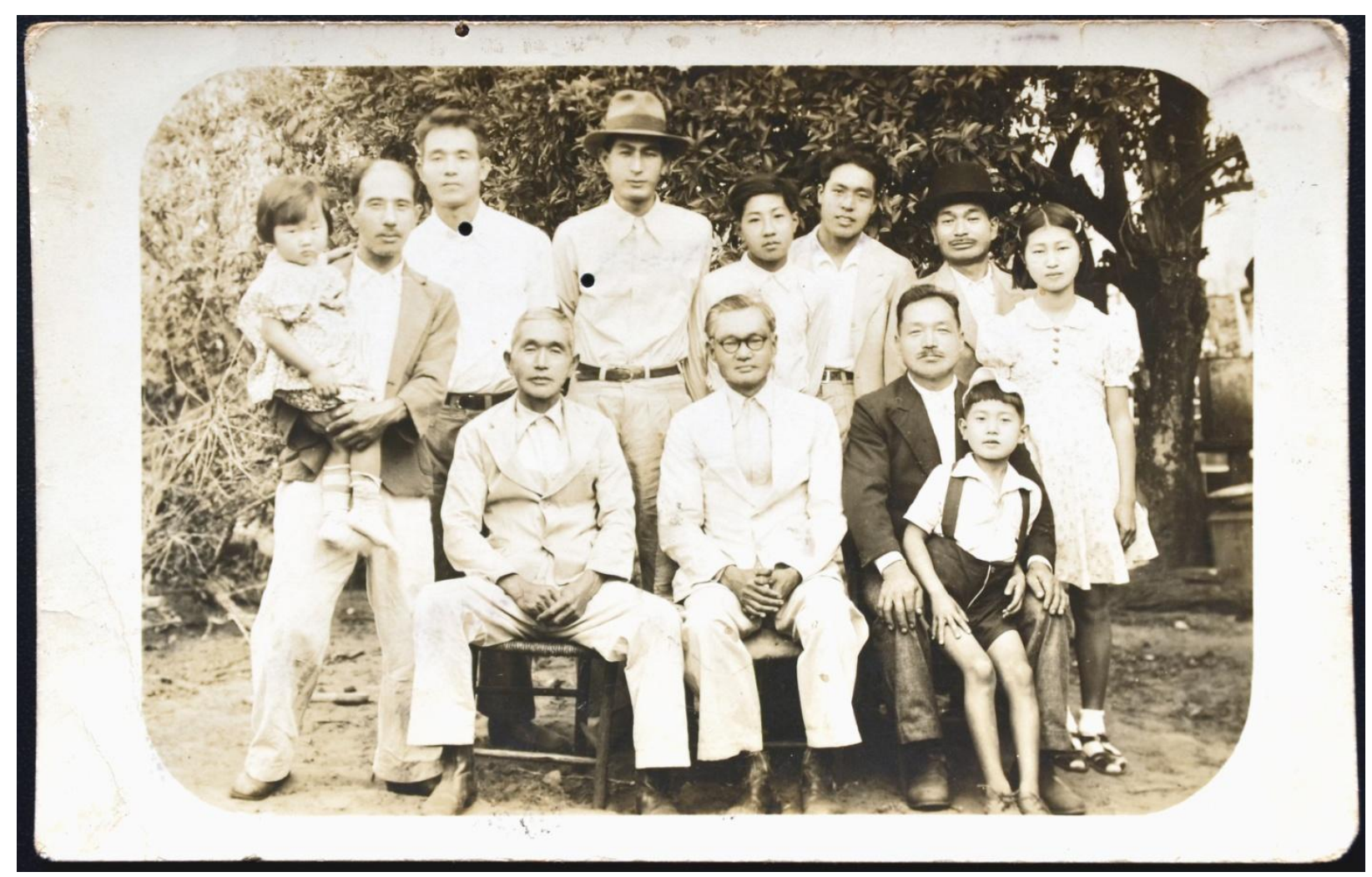

FIGURA 32. Fazenda São Joaquim. Mirandópolis, SP. 1943 


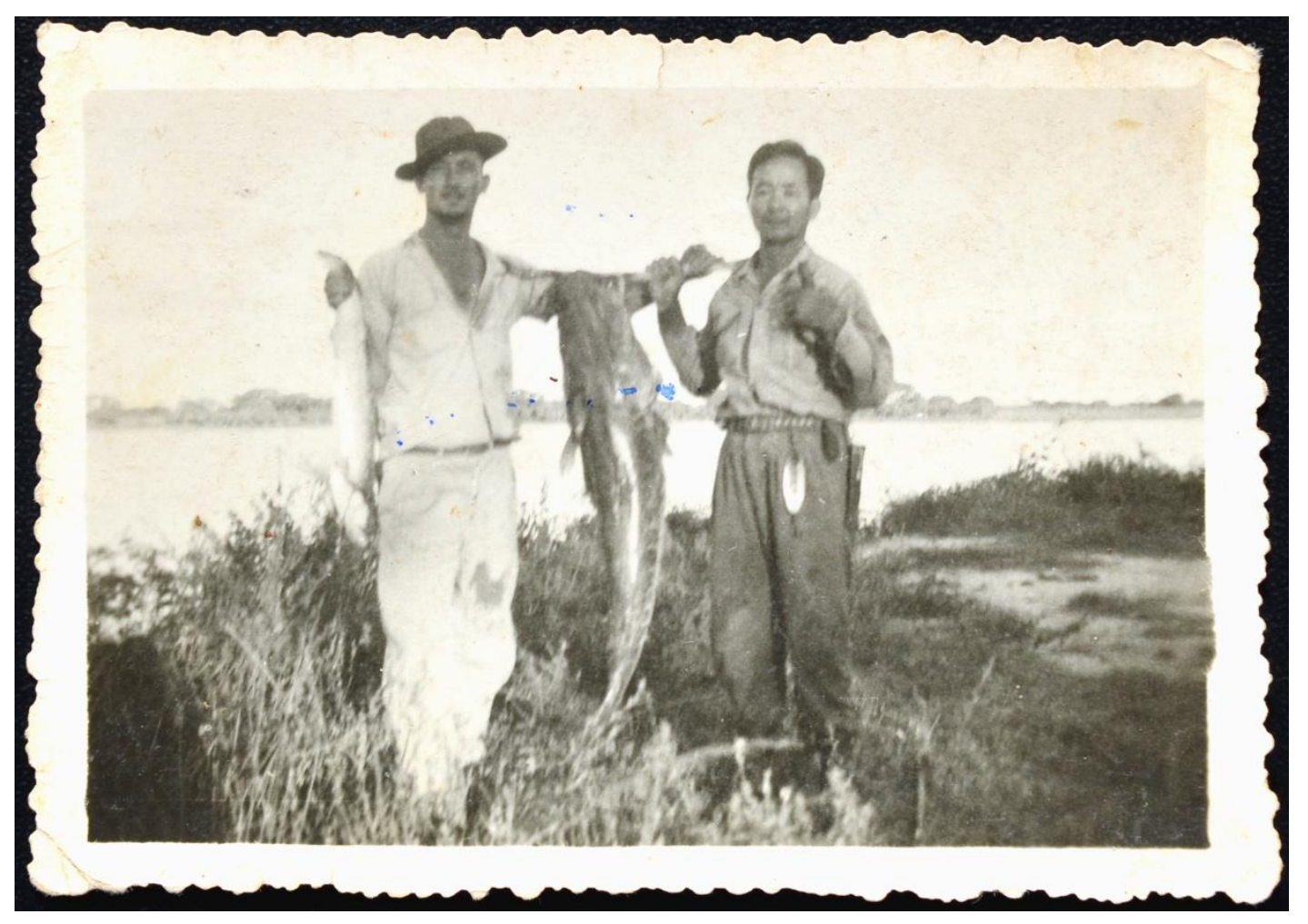

FIGURA 33. Alberto Padovine e Hideo Matsuyama. Mato Grosso do Sul. 1953 


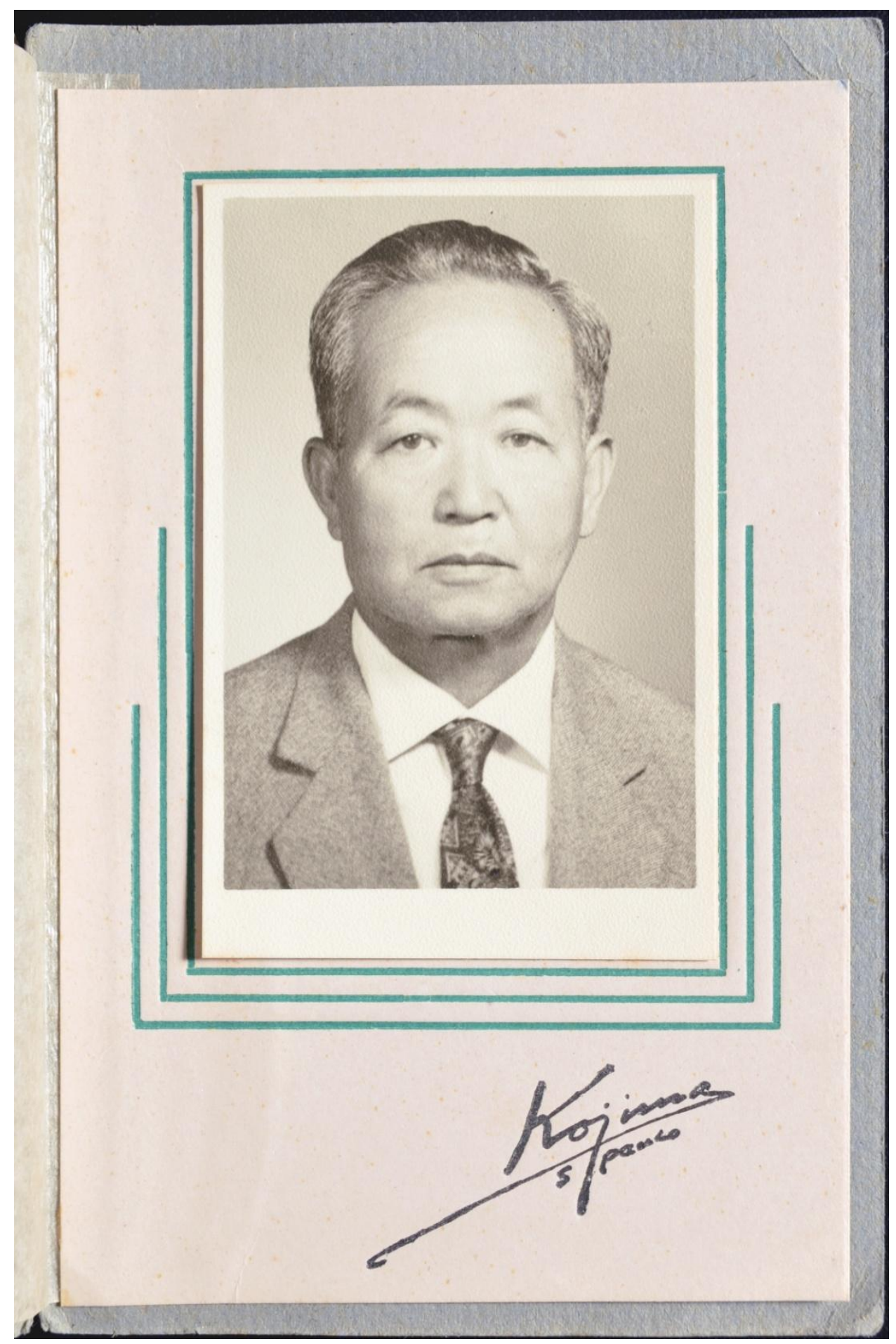

FIGURA 34. Hideo Matsuyama. São Paulo, SP. ca. 1960 


\subsection{Fotos avulsas em caixas}

Nem todas as fotos colecionadas pela família Matsuyama entraram nos álbuns.

Muitas delas permaneceram avulsas e foram guardadas em caixas por Akie. Há uma série de motivos que não figuram nos álbuns. Os temas mais chamativos são as fotos relacionadas ao trabalho e ao lazer (Figuras 30 e 33). Com sua câmera, Hideo registrou alguns lugares históricos (viagens), pescarias (lazer), construções em andamento (trabalho), membros da família e visitas a parentes, amigos, animais de estimação e de trabalho, e outros motivos (inclusive uma locomotiva chegando na estação de Avanhandava, em 1923, coincidentemente, um dos primeiros temas cinematográficos e um símbolo da modernidade industrial - ele foi funcionário da NOB, Estrada de Ferro Noroeste do Brasil).

Richard Chalfen (1991) nota em seu influente estudo sobre as fotos de imigrantes japoneses que o trabalho é uma categoria de fotos que raramente figura em álbuns de outros estadunidenses, e chega a suspeitar que essa categoria seria exclusiva dos imigrantes japoneses. Uma razão para isso, ainda segundo o mesmo autor, seria a tendência dos imigrantes japoneses em associar o sucesso econômico com o sucesso familiar. "O trabalho parece ser uma extensão da unidade familiar, assim, colegas de trabalho são tratados como membros da família estendida." (CHALFEN, 1991, p. 138)

A partir de um contexto diferente, André Rouillé também afirma que situações de trabalho são raras em álbuns de família europeus (ROUILLÉ, 2005, P. 243).

Em ainda outro contexto, Nelson Schapochnik observa sobre as fotos relacionadas ao trabalho, feitas no Brasil.

O mundo do trabalho também aparece nos álbuns de família. Patrões ou empregados posam geralmente com os atributos materiais e instrumentos que explicitam sua atividade. Corpos higienizados, roupas e uniformes alinhados, sapatos reluzentes aparecem como uma alegoria do sucesso e bem-estar, mas também denotam a complexidade e diversidade do mundo do trabalho numa era pautada pelo esforço de modernização e diversificação de atividades. A atitude deliberada de convocar um fotógrafo para registrar o cenário de trabalho pode ser interpretada como uma 
estratégia de autoconsagração e individuação que apontava para a valorização da distinção pela rivalidade e concorrência. Nesse caso, além de funcionar como um elemento que se integrava na construção da imagem heroica do homem que se deu bem na vida graças ao seu esforço, dedicação e racionalidade, essas fotografias indicam o processo de aburguesamento do retratado. (SCHAPOCHNIK, 1998, p. 484-5)

De qualquer modo, apesar de existirem fotos dessa natureza na coleção, elas não entraram nos álbuns da família Matsuyama, com a exceção de uma única fotografia da família Sakasegawa em sua plantação de tomate, já mencionada anteriormente.

Parece que um critério de seleção para figurar nos álbuns era o interesse familiar coletivo que uma determinada imagem poderia suscitar. Assim, interesses individuais foram deixados de fora.

Mesmo sem demonstrar uma narrativa, como nos caso dos álbuns, as fotos avulsas podem auxiliar a vislumbrar uma série de interesses das pessoas que as guardaram. Assim, os temas recorrentes, já mencionados por outros autores, como família, casamento, bebês e crianças, lazer, trabalho, viagens, etc., indicam os motivos caros ao coração. Longe de esconder as intimidades em favor de papéis sociais, as fotos temáticas, por se constituírem como tal através de sua repetição, marcam claramente (tão claramente quanto uma imagem fotográfica pode ser, ou seja, apenas fragmentariamente) os afetos pessoais. Ainda assim, de modo algum, as fotos de família achatam as pessoas e as tornam de tal forma semelhantes que se poderia ver nelas apenas estereótipos. É preciso apenas sensibilidade, paciência e atenção aos detalhes e ao que uma fotografia pode comunicar. Quando se exige da imagem fotográfica mais do que sua natureza permite que ela seja, invariavelmente, o resultado será frustrante.

Independentemente de terem sido organizadas de modo narrativo, as coleções de fotos invariavelmente revelam as intenções de seus possuidores. A neutralidade simplesmente não é possível. “Assim como existe um sentido para a preservação e exposição das imagens fotográficas que incidem sobre a memória familiar, certamente deve haver uma lógica interna presidindo a formação e organização das coleções." (SCHAPOCHNIK, 1998, p. 462) 
Há cerca de cento e setenta fotos de suporte em gelatina guardadas em diferentes caixas de papelão por Akie. Quarenta e quatro possuem 8 x $6 \mathrm{~cm}$; são fotos caseiras e referem-se a bebês e crianças, amigos, animais, viagens e pesca. Cinquenta e sete possuem 10 x 7 cm; são fotos caseiras e referem-se a bebês e crianças, família, amigos, trabalho, cenas rurais e urbanas. Cinquenta possuem 13 x $9 \mathrm{~cm}$; são fotos tanto de profissionais quanto amadoras e referem-se a casamentos, família, crianças, trabalho, viagens e gincanas (undokai). De maiores dimensões, 16,5 x $12 \mathrm{~cm}$, há apenas duas fotografias feitas por profissionais: uma de escola primária para meninas e uma cena rural de família. Há dezessete fotos que foram enviadas pela família Matsuyama do Japão: cinco 10 x $8 \mathrm{~cm}$ da família e das crianças, cinco 12 × $8 \mathrm{~cm}$ também da família e crianças e sete 9 × 6,5 cm dos sobrinhos de Hideo. Nem todas as fotos estão datadas, mas cobrem o período de 1910 a 1960.

Da mesma forma que nos álbuns fotográficos, os temas familiares são fundamentais nas coleções. Os retratos de família (Figuras 21, 24, 25 e 26), de casamento (Figura 23), de bebês (Figura 29), de crianças e jovens, de amigos, de animais de estimação (Figura 28), todos eles se referem à vida privada familiar. Tanto o círculo mais fechado quanto relações menos estreitas figuram na coleção. Evidente que, nas fotos avulsas, aparecem outras relações de amizade que não entraram nos álbuns, relações provavelmente mais superficiais e passageiras.

Alguns temas que proliferam na coleção de fotos avulsas mas que praticamente não aparecem nos álbuns são aqueles relacionados ao trabalho (Figura 30) e lazer (Figura 33). Dentre esses dois temas, há muito mais fotos de lazer e viagens do que de trabalho. Talvez uma razão para não terem entrado nos álbuns seja o fato da maioria ser fotos vernaculares, ou seja, produzidas com a câmera da família. Essas fotos possuem pequenas dimensões e a grande maioria apresenta baixa qualidade técnica. Então, talvez por esses motivos, tenham sido deixadas de fora dos álbuns. 
Talvez, ainda, lhes falte um ar de solenidade, uma certa respeitabilidade, necessária para ser uma parte que vai compor a história do grupo familiar. Sua característica instantaneidade contraria em alguma medida a ideia de eternidade expressa nos álbuns de fotografias.

Além das fotos e cartas guardadas em caixas de papelão pela família Matsuyama, também tive acesso às fotos guardadas numa caixa de madeira pela família Sakasegawa. Essa caixa de madeira foi confeccionada por Hideo, que era carpinteiro, e, provavelmente dada de presente para Eiji ou Ine.

Apesar de não terem sido organizadas em álbuns, as fotos que Ine guardou são mais variadas do que as de sua filha. Sua coleção possui cinco cartes-de-visite com suporte em gelatina, sendo que quatro delas foram realizadas no começo do século XX no Japão (Figuras 35 e 36), e uma foi feita no Brasil na década de 1920. Também consta um ferrótipo, variação mais barata do daguerreótipo, realizado em Iguape, em 1921. Além desses itens pouco comuns, a caixa contém cerca de cento e setenta fotos de gelatina. Dezenove possuem 7 x 6 cm e são fotos amadoras de viagens. Vinte possuem 8,5 x $6,5 \mathrm{~cm}$, dentre as quais, onze são fotos amadoras e referem-se a crianças, filhas, sobrinhas e cães, e nove são fotos de profissionais e referem-se a crianças, filhos, sobrinho e genro. Nove possuem 7 x $5 \mathrm{~cm}$ e são fotos amadoras de amigos, filhos e netos. Trinta e oito possuem $8,5 \times 7 \mathrm{~cm}$, dentre as quais, vinte são fotos de profissionais e referem-se a crianças e viagens, e dezoito são fotos amadoras da família. Vinte e seis possuem 11,5 x 8,5 cm, dentre as quais, treze são fotos de profissionais e referem-se a bebês, amigos, família e cenas rurais, doze são fotos amadoras de amigos, crianças e família, e uma, trazida do Japão, é um retrato de Ine com suas amigas. Trinta e duas possuem 13,5 x $9 \mathrm{~cm}$, foram realizadas por profissionais e referem-se a viagens, primeira comunhão, trabalho e colegas de trabalho, amigos, família, casamentos, bebês e grupos escolares. Dezessete de 17 x $12 \mathrm{~cm}$ são trabalhos de profissionais e referem-se a cenas 
rurais, casamentos, amigos, trabalho e colegas de trabalho, primeira comunhão, família e grupos escolares.

Mesmo sem ter sido organizada em uma forma narrativa, a coleção fotográfica de Ine Sakasegawa exibe temas que cercam a vida familiar e contam histórias sobre a família da qual ela fazia parte. Ao olhar para as fotos que compõem a coleção, a impressão que se tem é a de estar diante de fragmentos da vida de uma imigrante japonesa e de suas famílias, nuclear e estendida, e amigos. Assim, as intenções que nortearam a formação da coleção através dos anos são claras e inequívocas.

Novamente, os temas recorrentes à família são os retratos de família, de casamentos, de filhos e netos, e de atividades familiares como visitas, reuniões e festas. Apesar disso, outros temas familiares também aparecem, como animais de trabalho e de estimação, primeiras comunhões, trabalho (Figuras 31 e 32), lazer, etc. Por não estarem compartimentadas na forma de álbum fotográfico, as fotos avulsas possuem maior elasticidade temática.

Na coleção de Ine ainda é possível notar as relações que ela mantinha com parentes e amigos na terra natal. Diferentemente de Hideo, que saiu do Japão com doze anos de idade, Ine deixou a terra de seus antepassados com cerca de vinte anos. Assim, sua experiência e vínculos têm maior profundidade e diversidade. As relações que Hideo mantinha no Japão giram quase que exclusivamente em torno de sua família nuclear (pais e irmãos). No caso de Ine, há maior incidência da família estendida e de amigos. Por conta disso, torna-se mais difícil dizer quem são as pessoas em muitos dos retratos em sua coleção. Afinal, quanto mais longe do centro familiar, mais fugidios são os registros passíveis de consulta. Em outras palavras, os retratos de amigos são aqueles que apenas ela poderia reconhecer. Também por conta da diferença de idade, a coleção de Ine possui cinco cartes-de-visite, uma forma fotográfica típica do final do século XIX, que não aparece no espólio de Hideo e Akie. Apesar 
das cartes-de-visite de Ine serem do começo do século XX, elas indicam uma prática e consumo de imagens que estava caindo em desuso. Assim, Ine ainda participou dos últimos anos de produção dessa forma fotográfica tão particular.

Há uma diferença básica na forma que Ine e Hideo consideravam a fotografia. Ine não possuiu uma câmera, foram seus filhos (Toshio, por exemplo) que adquiriram câmeras e produziram retratos familiares. A atitude de Ine, em relação ao ato fotográfico, parece ter tido um quê de passividade (nada absoluto, afinal ela encomendou diversos retratos a profissionais, além de ter mandado fazer uma reprodução de um antigo retrato seu, como se verá mais adiante). Hideo, por outro lado, teve pelo menos duas câmeras (uma antes da guerra, outra após), o que necessariamente fez com que ele tivesse de assumir uma posição mais ativa, para produzir imagens com uma câmera sua.

Apesar de não ser o objeto deste estudo, devo também notar que na caixa de Ine existem muitos recortes de revistas especializadas que retratam artistas japoneses contemporâneos. Um motivo para isso é o contínuo interesse pelas artes nipônicas mesmo após a imigração ao Brasil. Outro motivo correlato é a identificação de Ine com artistas de mesma nacionalidade que a sua, ou seja, que possuíam um universo de referências culturais em comum. É possível e provável que Ine se divertisse e se identificasse com artistas brasileiros também. Desse modo, a identidade dos imigrantes surge como algo multifacetado, nem unicamente japonês, nem exclusivamente brasileiro.

À semelhança dos álbuns, as fotos avulsas também possuem intenções de contar a história do grupo familiar. Apesar de ainda menos ordenadas, essas coleções não deixaram de se orientar pela vida familiar. Uma diferença notável é que os cantos estão menos polidos, a organização temática é mais solta, e menos rígida. Há lugar para alguns assuntos que talvez o álbum não comportasse. A falta de organização e a consequente desnecessidade de eloquência conferem às coleções de fotos mais liberdade e maior diversidade. 


\subsection{Correspondência (cartas)}

Junto às fotografias, havia diversas cartas, todas escritas em japonês, nas caixas com pertences íntimos de Akie Sakasegawa Matsuyama. Trata-se de cartas escritas por seus parentes e amigos no Brasil, além de cartas recebidas do Japão da família Matsuyama. Não foi possível saber em quais correspondências vieram as fotografias, pois as cartas e as fotos já estavam separadas e os poucos envelopes remanescentes, vazios. Apesar de apenas seis cartas estarem datadas (entre 1946 e 1962), é possível perceber que esse conjunto de cartas foi recebido no período após a Segunda Guerra Mundial, devido ao estilo linguístico e às idades mencionadas nos textos. As cartas recebidas antes da guerra provavelmente se perderam durante o período de conflito, quando a circulação de cartas ficou proibida. Mais do que isso, possuir qualquer material escrito em japonês (ou, em alemão, também) era ilegal.

As cartas guardadas foram escritas pelos irmãos de Hideo (quinze cartas ao todo, dez de Fumi), tios e cunhados (três) e sobrinhos (duas). Escritas pelo casal Sakasegawa, há cinco, e, ainda, redigidas por primo (uma) e amigos (três). Há também quatro cartas que Hideo escreveu, mas não postou. Duas para parentes no Japão, uma para os sogros no Brasil, e uma para um amigo, também no Brasil.

Os tópicos são diversos, porém, na maior parte do tempo, típicos: saúde, trabalho, escola, visitas, etc. Há ainda menções a dívidas, empréstimos e pagamentos. Elizabeth Bott (1971, p. 102), em seu estudo sobre as relações familiares, nota que laços econômicos, auxílios financeiros e empreendimentos conjuntos são fatores que aumentam a união (“connectedness") na rede de parentesco e amizade.

Hideo e a família Sakasegawa (creio que outras famílias também), enquanto não se estabeleceram em uma cidade, recebiam suas correspondências do Japão através dos irmãos Ohara, para quem Eiji trabalhou em diversas ocasiões. Seus negócios com máquinas para beneficiar café e arroz eram prósperos, o que conferia a seu estabelecimento um endereço fixo 
(coisa que a família Sakasegawa por muito tempo não possuiu; a constante mudança de endereço e emprego prejudicava um pouco a comunicação com os parentes na terra natal, mas, através da amizade com a família Ohara, ela pôde ser mantida quase que regularmente). Conforme Françoise Noël, a correspondência era fundamental para manter os laços de parentesco.

A correspondência, embora geralmente entre dois indivíduos, mantém um número muito maior de indivíduos informados sobre o bem-estar de amigos e parentes. Embora manter uma correspondência regular claramente atende a uma necessidade emocional, ela também serve para manter uma rede de apoio social. (NOËL, 2003, p. 272)

Fato que Wendy Cameron, Sheila Haines e Mary McDougall Maude reiteram em sua compilação de cartas.

\footnotetext{
Uma carta muitas vezes servia a muitas pessoas. Além de serem mostradas aos membros da família, os autores repetidamente pediam para que elas fossem mostradas a amigos ou a pessoas que haviam pedido, antes da partida, por um relato sobre as impressões do novo país (...) Se os imigrantes estivessem dispostos a incentivar a emigração - muitos preferiam uma posição neutra - eles indicavam pessoas que deveriam ser convocadas, algumas vezes sugerindo que as cartas fossem mostradas a elas. (CAMERON; HAINES; MAUDE, 2000, p. XXX)
}

O conteúdo das cartas era desconhecido aos filhos do casal Matsuyama, devido à ignorância da língua japonesa. Tanto a família Sakasegawa quanto a família Matsuyama, uma vez no Brasil, sentiam que a educação japonesa não seria de grande utilidade aos filhos. Ambas as famílias puseram ênfase no aprendizado da língua portuguesa, pois sua urgência era maior. Mesmo antes da Segunda Guerra, quando a grande maioria dos imigrantes relegou a segundo plano a educação nipônica, as famílias em questão já tinham como certa a necessidade de plena convivência no meio que os cercava. Por isso, a língua portuguesa obnubilou o aprendizado do japonês. Desse modo, há raras fotos de grupos de escolas 
japonesas. Por outro lado, são abundantes as fotos de grupo escolar em instituições brasileiras e as de formatura em trajes ocidentais.

De qualquer modo, os filhos do casal Sakasegawa cursaram, paralelamente à escola brasileira, o curso de japonês em escolas da colônia; nenhum chegou a completar o curso, mas todos tinham alguma noção da língua nativa de seus pais. Já os filhos do casal Matsuyama não chegaram a cursar as escolas de japonês. Eiji e Ine conversavam em japonês entre si e em casa, o que deve ter auxiliado a fixação da língua japonesa nos filhos em alguma medida. Também Hideo e Akie conversavam entre si em japonês, mas não exclusivamente, e isso deve ter, por outro lado, enfraquecido a possibilidade de aprendizado da língua (mesmo que apenas a fala coloquial) entre os filhos.

A grande maioria dessas cartas, guardadas por Akie, foram traduzidas por um colaborador desta pesquisa, senhor Takashi Kayano, a quem devo profundos agradecimentos. Um primeiro problema da tradução foi certa ilegibilidade de parte das laudas. Outro problema é que as cartas não foram guardadas em seus envelopes e poucas estavam datadas. Um outro problema foi que algumas páginas se misturaram, através dos anos, e as sequências foram alteradas ou perdidas.

De qualquer modo, sua importância foi a possibilidade de constatar a continuidade das relações entre a família Matsuyama, mesmo muitos anos depois da imigração de Hideo.

Sua principal pertinência a esta pesquisa se deve aos trechos onde as fotos são mencionadas. Através dessas cartas, pude asseverar que a troca de fotos se deu através da correspondência entre Japão e Brasil. Hideo saiu de Kagoshima aos doze anos e nunca mais voltou à terra natal. A única forma de se fazer conhecer, como adulto, e de fazer conhecer sua família aos parentes no Japão foi através da fotografia. Da mesma forma, o desenvolvimento da família Matsuyama (nascimento de novos integrantes e envelhecimento dos antigos) só pôde ser conhecido através das fotos recebidas. "Como uma forma de comunicação 
interpessoal, a troca de fotografias pode servir como uma espécie de laço simbólico que reúne membros da família que moram longe uns dos outros.” (CHALFEN, 1991, p. 163).

A troca de cartas e fotos é de extrema importância para a manutenção das relações. Sem ela, a comunicação simplesmente não seria possível e os contatos se perderiam. No entanto, isso não é o suficiente. Estar frente a frente, poder olhar-se nos olhos, sentir os cheiros das pessoas, ouvir as vozes e risadas, dividir a mesa, nada pode substituir o encontro factual. O sentimento de saudade fica ainda mais pungente conforme a idade vai pesando. As duas irmãs mais velhas de Hideo, Mine e Shina, escrevem uma carta em julho de 1960:

\begin{abstract}
Saudações! Desculpe-nos por escrevermos poucas cartas, mas não esquecemos a separação há 24 anos e sempre pensamos em vocês. Aqui, como você sabe, o pai fez 78 anos, a mãe 71 anos, Mine 57 anos, e Shina 55 anos. Todos já são velhos. A mãe está com problema no pé direito e o pai, com o avanço da idade, não pode trabalhar como antes. A vida em casa está muito difícil. A Shina também não está passando bem este ano. Aqui, estamos nessa situação. Pedimos que vocês regressem logo, ainda este ano, se for possível, enquanto os pais ainda estão fortes. Não sabemos até quando a vida da gente pode aguentar, por isso, pedimos que voltem no fim deste ano ou até a primavera do ano que vem. Sabemos que viajar com crianças é difícil, mas rogamos que voltem com urgência. E pedimos o obséquio de dar notícias ao senhor Kaichiro Otsuji e enviar saudações da família. Tenho muitas coisas para escrever, mas deixo para a próxima carta, esperando sua missiva.
\end{abstract}

Infelizmente, Hideo nunca pôde retornar à terra natal; assim, nunca mais reencontrou sua família. Seus pais, Kojiro e Kesa, faleceram poucos anos após a remessa dessa carta.

Na ocasião de falecimento de Hideo, as fotos trocadas ganharam um significado especial, o de substituir a pessoa em si. Françoise Noël, assim como Jay Ruby (1999), corroboram essa visão e indicam que os retratos serviam como substitutos para o corpo no luto.

Trecho de uma carta de Fumi para Akie, após o falecimento de Hideo, sem data (após 1962): 
Recebi a notícia de falecimento de Hideo, mas não tive oportunidade de manifestar meu pesar, por esse motivo, eu sinto profundamente. Fiquei sabendo que Hideo faleceu depois que foi operado do estômago, e imagino o quanto ele lutou pela família. A senhora deve estar muito chocada com esse acontecimento, eu gostaria de consolá-la pessoalmente, mas a distância impossibilita. Assim, expus a fotografia de Hideo e pedi ao bonzo (sacerdote budista) para orar e comunicar a seus antepassados.

Trecho de uma carta de Fumi para Akie, sem data (após 1962):

\begin{abstract}
À Deicy, Satiko e Neli, todas já bem crescidas, recomendo tratar bem da mãe e da casa, eu sempre estarei pensando em vocês. A senhora Akie foi uma esposa excelente, criou seus filhos com carinho e lutou sempre ao lado do amado marido, encorajando e lutando sempre, no país distante. Estou arrependida agora por não ter escrito com mais frequiência para Hideo, porém, agora estou colocando as coisas diante da foto enfeitada do falecido. Ia mandar alguns objetos, mas é muito difícil, segundo informação do correio, portanto estou esperando a oportunidade adequada. As cartas que recebemos de sua família, mandamos para as famílias de meus irmãos (maior e menor). Depois, foram colocadas em frente de fotos do pai, da mãe e de irmãos já falecidos, para consolar os antepassados.
\end{abstract}

Em outra carta, de Fumi para Akie, também sem data (após 1962):

A carta e a fotografia que nos mandou, mostrei a todos os parentes, os quais ficaram muito contentes. Também para a irmã que mora em Yakushi remetemos em primeiro de novembro. Ela expôs junto com doces, frutas e demais coisas e comunicou aos antepassados. E, no dia dez de novembro (dia em que faleceu o senhor Hideo), rezou perante a fotografia dele. Eu também, em dez de novembro, juntamente com a fotografia, flor de crisântemo, doces e frutas expostos no altar, rezei a benção do senhor Hideo.

Fumi continuou a se corresponder com Akie depois da morte de Hideo. Numa dessas cartas, ela lista os filhos dos irmãos, sobrinhos de Hideo. Através da carta que Hideo escreveu mas não enviou ao Japão, pode-se ver que ele também atualiza os empregos e a escolaridade dos diferentes filhos. Para Fumi, o número de parentes sobre os quais ela teria de informar é muito maior do que os familiares no Brasil. Assim, ela recorre a uma espécie de diagrama genealógico. Esses três tipos distintos de textos, fotografias, cartas e diagramas genealógicos, são centrais para a construção do ideal da família moderna. “As cartas podiam ser mais 
importantes por seu valor simbólico do que pelas informações que de fato continham.”

(NOËL, 2003, p. 271)

A figura da mãe aparece em algumas cartas, a do pai, é mais circunspecta. A ligação entre mães e filhos é um importante aspecto da cultura japonesa, conforme Takeo Doi (1973). A dor da mãe pela separação torna-se explicitamente visível após seu falecimento.

Em uma carta (sem data) de Taka, esposa de Masao, para o cunhado, Hideo, ela conta sobre os últimos dias da mãe, Kesa:

Sua mãe sempre falava de você, que partiu daqui aos 12 anos de idade, nem consigo calcular sua idade atual, pois faz muito tempo. Numa visita que fiz a sua mãe, ela estava olhando suas fotos e me mostrou algumas de suas muitas fotografias. Dois ou três dias depois, ela sofreu um derrame. Nós queríamos salvá-la a qualquer custo, mas foi impossível. Apesar de todos os cuidados, ela faleceu após doze dias. Como seu irmão era professor de uma escola para meninas, todas as alunas participaram do enterro de sua mãe.

Em outra carta (sem data) para Hideo, Fumi comenta sobre a mãe:

Desde criança nos separamos, longe em um país estrangeiro, não tive nenhuma oportunidade de encontrá-los. Mamãe sempre falava de vocês, até na hora de morrer.

Em diversas outras cartas, é possível identificar a sede e o desejo por fotografias, de ambos lados, pois era a única forma que as pessoas tinham de se ver.

Um trecho final, de uma carta escrita por Satsuo para seu irmão Hideo (sem data):

Tenho muitas saudades de você, me mande fotografias da família e escreva sobre a vida daí, que eu também mandarei cartas sempre. E cuide bem da saúde.

Em suma, a correspondência era o que tornava a troca de fotografias possível.

(...) enviar uma fotografia para parentes é precisamente uma prática que representa a família. (...) As fotografias que circulam na forma de presentes, então, são objetos de 
peso, densos não somente com a presença dos retratados nas fotos, mas também com os traços da pessoa que as está enviando. (ROSE, 2010, p. 64)

Françoise Noël, em seu estudo sobre diários e correspondência familiar, também nota que os retratos eram uma parte importante da herança familiar. Com o advento da fotografia, cada vez mais os apelos para que os retratos fossem feitos e enviados eram abundantes. Antes disso, retratos pintados à óleo, pastéis, miniaturas e silhuetas eram mais comuns. Nesse estudo, a pesquisadora encontrou diversos retratos junto às cartas e diários, o que parece, novamente, comprovar os laços intrínsecos entre esses documentos.

As cartas escritas, trocadas e guardadas por pessoas comuns começaram há pouco a atrair a atenção de diferentes pesquisadores. Além de Noël, destacam-se, ainda, Alain Boureau, Roger Chartier e outros (1991), Cécile Dauphin, Pierrette Lebrun-Pézerat e Danièle Poublan (1995), Wendy Cameron, Sheila Haines e Mary McDougall Maude (2001), e Irene Nogueira de Rezende (2004). Bem como a coletânea de artigos, Teresa, revista de literatura brasileira, número 8/9 (2008), dedicada a correspondências.

Muitos desses autores comentam que a correspondência é repleta de conteúdos afetivos implícitos. As cartas podem revelar muito sobre as relações mantidas entre as várias partes da família, mas elas nunca revelam absolutamente tudo de maneira cristalina. É evidente que o quanto elas podem dar a conhecer depende da natureza das pessoas que escrevem e do modo particular como lidam com a linguagem. O quanto elas podem informar também depende muito do modo como elas foram guardadas.

A correspondência que pude avaliar é fragmentária, não acredito que tive acesso a todas as cartas trocadas entre as famílias. As muitas mudanças de endereço (de ambas as partes) fizeram com que muitas cartas se perdessem. A guerra foi outro fator de dispersão, assim como um pouco de descuido dos descendentes. Dessa forma, as cartas que utilizei são apenas um vislumbre de uma totalidade perdida. Mas, de qualquer modo, qualquer totalidade é apenas uma idealização. 
Muitos dos pesquisadores que se debruçam sobre o tema das correspondências afirmam que é incomum as pessoas derramarem abertamente seus sentimentos e darem completa vazão ao que o coração estima, talvez com a exceção das cartas de amor entre duas pessoas exclusivamente. Assim, um dos motivos para certa reserva é o fato de muitas pessoas terem acesso às cartas, ponto já notado mais acima, conforme Nöel. Isso de maneira alguma indica frieza ou artificialidade nas relações, pelo contrário, apenas aponta para um consenso sobre o bom-tom das redações. Apesar da conhecida reserva nipônica, principalmente em relação aos sentimentos, as cartas que consultei são cheias de emoções declaradas. Apesar de provavelmente possuírem muitos conteúdos implícitos inapeláveis, o que está expresso em muitas delas são corações generosamente abertos, talvez pelo fato de que as cartas eram a única e exclusiva forma das pessoas se comunicarem.

Depois de se aposentar, em busca de suas origens, a filha mais nova do casal Matsuyama, Neli, minha mãe, através do empenho e da boa vontade da senhorita Kumiko Kamihogi, bolsista da Associação Cultural (Kenjinkai) da província de Kagoshima, conseguiu o endereço atual de Fuyoko Shinmyozu, filha de Fumi, irmã de Hideo. Fumi era uma das pessoas que mais escrevia para Hideo.

Uma das cartas guardadas por Akie foi remetida por essa filha de Fumi, Fuyoko, que nunca conheceu o tio Hideo. Mesmo assim, ela escreveu uma carta, na tentativa de manter as relações familiares, ainda que muito distantes. Uma coisa curiosa é que nessa carta ela pergunta se o tio Hideo não possui uma filha, mais ou menos da idade dela (na época, com cerca de vinte anos), com quem ela pudesse manter correspondência. Nem passava por sua cabeça que seus primos no Brasil não eram alfabetizados na língua japonesa.

Cerca de cinquenta anos depois do envio dessa carta, esse contato foi reestabelecido. Atualmente, minha mãe, Neli, se corresponde regularmente com a prima, Fuyoko. A barreira linguística persiste; a princípio, como Neli sabe pouco japonês, elas tentaram se corresponder 
em inglês, mas devido à dificuldade de Fuyoko com essa língua, as cartas agora são escritas em japonês. Da parte do Brasil, um tradutor é necessário, tanto para traduzir o que Neli quer enviar para a prima, quanto para traduzir as cartas recebidas. Além das cartas, pequenos presentes também são enviados pelo correio, em datas como Natal e aniversários.

Em minha visita à Kagoshima, Fuyoko mostrou-me três cartas recebidas por sua mãe, Fumi, da família no Brasil. Uma, escrita em inglês, é de autoria de minha mãe, Neli, em comemoração do natal de 1965. Outra foi escrita por minha avó Akie para informar a ocasião, a data e as circunstâncias (em decorrência de uma cirurgia de câncer no estômago) de falecimento de meu avô, Hideo. Essa é uma missiva curta, de poucas linhas, com palavras pesarosas e inconsoláveis. Lágrimas de muitas pessoas caíram nessa página, e evaporaram sem deixar marcas.

A última foi escrita por Hideo e começa por assuntos triviais: comunica que a família está bem e pergunta pela saúde dos familiares no Japão. Em seguida, pergunta se ela recebeu a carta anterior. Pela falta de resposta, ele não sabia se ela havia sido entregue. Parece que houve uma perda de contato temporária, fato que o deixou muito triste, se sentindo solitário. Assim, ele comunica seu novo endereço em Lins. Nessa carta, ele ainda pede por fotografias da família e lamenta a distância e a impossibilidade de se visitarem. Essa carta é, como as demais, muito tocante, pois é possível sentir as saudades nas palavras do autor.

Após deixar o Japão, continuo a escrever para Fuyoko e seu filho, Makoto, exatamente pelo desejo de manter as relações familiares. Minha viagem ao Japão serviu, acima de tudo, para reestabelecer os laços familiares. Apesar de minha estadia ter sido extraordinária e de termos estreitado as relações nesse período, caso a correspondência cesse, os laços novamente se tornarão frouxos, com o risco de se perderem mais uma vez.

Devo novamente ressaltar que a maioria das cartas utilizadas foram encontradas no espólio do casal Matsuyama, guardadas por Akie, no Brasil. Outras poucas cartas foram 
encontradas no espólio de Fumi, irmã de Hideo, guardadas por Fuyoko, no Japão. Não foi possível consultar as cartas guardadas pelo casal Sakasegawa, uma vez que foram queimadas após o falecimento de Ine, junto com um diário de Eiji. Irene Nogueira de Rezende ressalta que essa "piromania documental" (2004, p. 21) está longe de ser incomum. As motivações para essas ações são diversas, assim como seus resultados. Desse modo, quem decide o que vai ser destruído e o que vai ser conservado segue escolhas pessoais de várias ordens. Não obstante, Toshio me disse repetidas vezes que se arrependia muito em não ter guardado esses documentos de seus pais. Assim, creio que essa perda foi fruto de um ato impensado mais do que resultado de uma motivação deliberada.

\subsection{Repetição de fotos entre parentes}

As principais coleções consultadas foram as do casal Hideo e Akie Matsuyama, guardado pela filha Satiko, e de Eiji e Ine Sakasegawa, guardado pelo neto Honório. Honório, a propósito, está no Japão, trabalhando em Shizuoka; mantemos contato via e-mail, através do qual posso fazer eventuais perguntas sobre a família, que assumem o caráter de questionário não estruturado.

As entrevistas não estruturadas com fotografias que conduzi tomaram a feição de visitas sociais. Afinal, todas as pessoas que entrevistei fazem parte da minha família, seja ela nuclear ou estendida. Todos os entrevistados sabiam que eu estava fazendo uma pesquisa acadêmica e aceitaram de bom grado em ajudar. Desse modo, tive muita liberdade para tomar notas durante os encontros, e, eventualmente, fazer registros audiovisuais. Todas as conversas giraram em torno das fotografias da família e das memórias. No início, eu mostrava as fotos que havia recolhido e, em seguida, em geral, as pessoas me mostravam as fotos que elas haviam guardado. Muito desse material foi confiado a mim para que fizesse reproduções para 
minha pesquisa. Essas novas cópias também serviram para que as famílias pudessem conservar seu acervo fotográfico.

Conheci um pouco os filhos do casal Sakasegawa, Munenori e Toshio. Na visita à Munenori, Satiko, minha tia, acompanhou-me, assim como nas conversas com Toshio, hospedadas por uma outra tia minha, Luci, e seu marido, Kikuo Nakamura. Passei bastante tempo com Toshio, tivemos conversas agradáveis, creio que foi bom para ele falar desses assuntos com alguém que estava disposto a ouvir, mas que tem também certa noção sobre eles (faz perguntas pertinentes, que revelam que uma pesquisa prévia foi realizada, por exemplo). Senti que isso fez bem para Toshio, mexer com suas lembranças e rememorar a história de sua família, reelaborar e desabafar seus sentimentos.

Também visitamos, Satiko e eu, o neto de Eiji e Ine, Sérgio, filho de Matsuo, assim como a sobrinha de Ine, Kiwa Makinodan Irino. Esta última se interessou deveras por meu estudo e, portanto, nos encontramos diversas vezes. Ao longo dos encontros, sua confiança em mim foi aumentando, assim como nossa intimidade.

Como já mencionado, a irmã de Ine e seu marido, Keisuke Makinodan, pais de Kiwa, também vieram ao Brasil no Kanagawa-maru, em 1912. Este ano, 2012, portanto, Kiwa encomendou uma cerimônia budista em memória aos cem anos de chegada dos antepassados, no templo Nambei Honganji Brasil Betsuin, no bairro do Ipiranga.

Por fim, fui sozinho à Kyushu, no Japão, para encontrar uma parte da família estendida Matsuyama. Em Kagoshima, fiquei na casa de Fuyoko, sobrinha de Hideo e Akie, e sua família, Shinmyozu. O neto de uma irmã mais velha de Hideo levou-nos à província de Kaseda, lar das duas famílias, Sakasegawa e Matsuyama. Em Kumamoto, fiz um passeio com outras duas sobrinhas de Hideo, Ichiko (Figura 27) e Hisako, filhas de seu irmão mais novo, Satsuo. Nessa última ocasião, Fuyoko levou cartas e fotos que, durante o almoço, foram de 
extrema utilidade para que pudéssemos todos visualizar as ramificações da família Matsuyama.

Em todos os lares que visitei, encontrei fotos que se repetem. A reprodutibilidade fotográfica é o que faz com que diversas imagens possam ser trocadas, além de reiterar os modos pelos quais diferentes membros da família se reconheçam entre si. A repetição de fotos em lares diversos comprova que trocas ocorreram de fato e que determinadas imagens realmente são significativas para as pessoas retratadas. As fotografias encontradas com diferentes membros das famílias Matsuyama e Sakasegawa e parte de suas famílias estendidas se referem a retratos de família, casamento e crianças, principalmente. A reunião da família em retratos fotográficos é importante pois mostra a união do grupo e evidencia que, mesmo um processo dispersivo como a migração, não chegou a separar todas as suas partes e não isolou os indivíduos do convívio familiar. O casamento também é um rito familiar de peso pois marca o enlace através do qual a família poderá alcançar a continuidade. E, os bebês, as crianças e os jovens, enfim, os descendentes são essa continuação da história familiar. É através deles que o nome da família será perpetuado. Desse modo, os temas mais importantes para a família são aqueles que contam sua história, mesmo que fragmentariamente.

As fotografias servem também para que os diferentes membros da família se reconheçam nos semblantes uns dos outros.

Carta de Fumi para Akie, sem data:

Soube que Shigeru (Milton) se casou e tem um filho que já começou a andar, gostaria de conhecer a esposa dele. Pela foto, achei Shigeru igualzinho ao meu irmão, Masao, e ao terceiro filho dele, Masashi. A Luci é mais parecida com o pai, interessante o efeito do laço sanguíneo.

Carta da esposa de Satsuo (irmão de Hideo) para Akie, sem data: 
Recebi sua prezada carta e fiquei imensamente grata. É uma pena que Hideo faleceu antes que eu pudesse conhecê-lo pessoalmente. Em casa, temos quatro filhas e um filho, que é o terceiro, Takafumi. O marido Satsuo é costureiro e sempre fica em casa. O filho Takafumi está muito contente de ter recebido a carta e pede todo dia para eu escrever a resposta. Ele acha que o Shigeru e o Masao são parecidos com um amigo.

Cameron, Haines e Maude também apresentam um exemplo desse passatempo familiar (2000, p. 331). As semelhanças físicas são uma forte evidência de pertencimento ao mesmo grupo familiar. Assim, a procura e o reconhecimento de aparências são atos comuns à fruição de fotografias de família. Para os imigrantes, como a única forma de conhecer certos parentes era através de retratos, traços físicos similares eram um reconforto familiar e a reafirmação do sentimento de pertencimento. O que se busca nesses exercícios é a união familiar expressa na genética, o que gera a impressão de que os laços consanguíneos são eternos e inquebrantáveis.

Ao discutir como o valor de culto havia de regredir frente ao valor de exposição, Walter Benjamin, apesar de não se dirigir especificamente às fotos vernaculares em seu famoso ensaio, comenta: "O refúgio derradeiro do valor de culto foi o culto da saudade, consagrada aos amores ausentes ou defuntos. A aura acena pela última vez na expressão fugaz de um rosto, nas antigas fotos. É o que lhes dá sua beleza melancólica e incomparável.” (BENJAMIN, 1985, p. 174) 


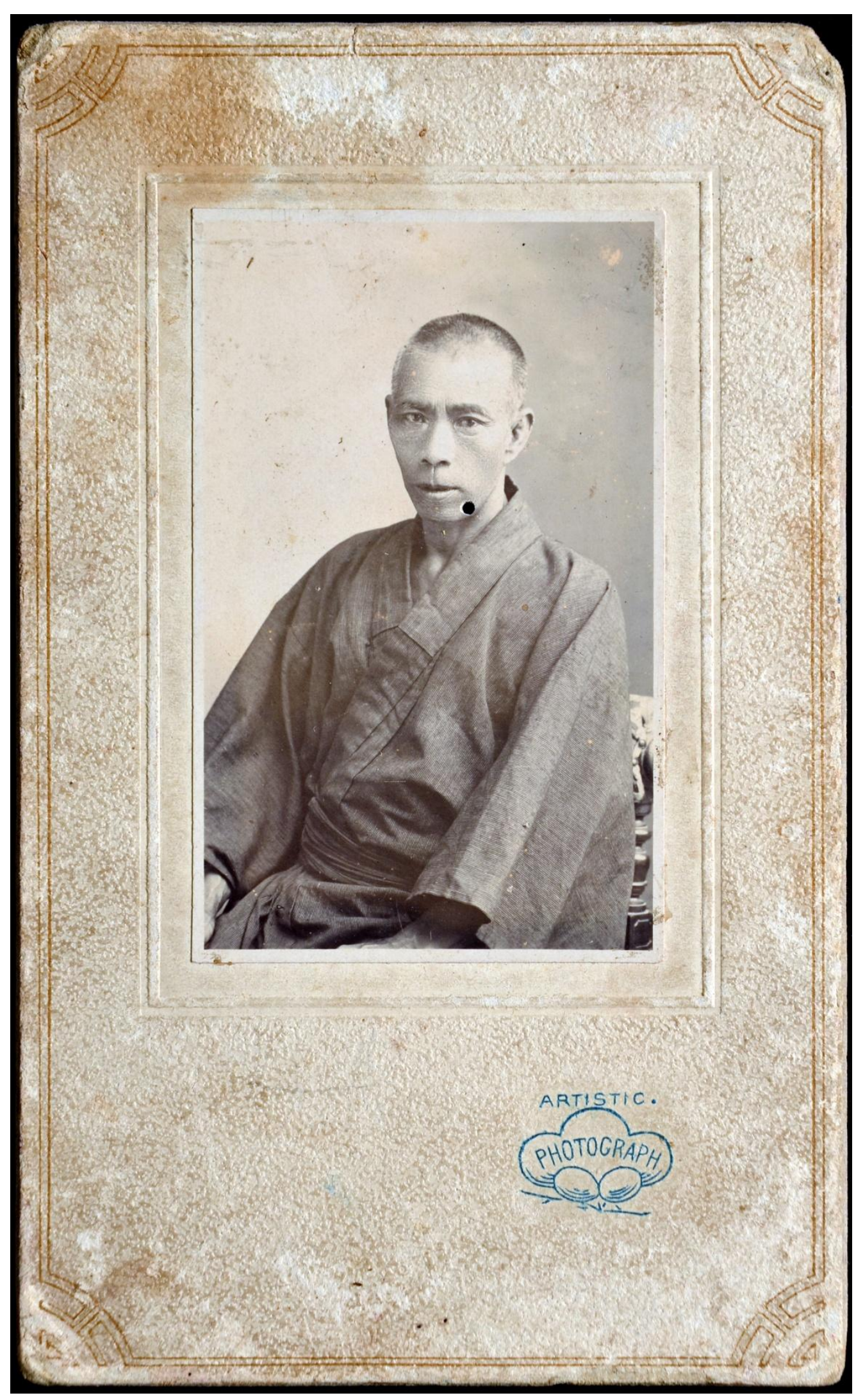

FIGURA 35. Soemon Sakasegawa. Kagoshima, Japão. ca. 1900 


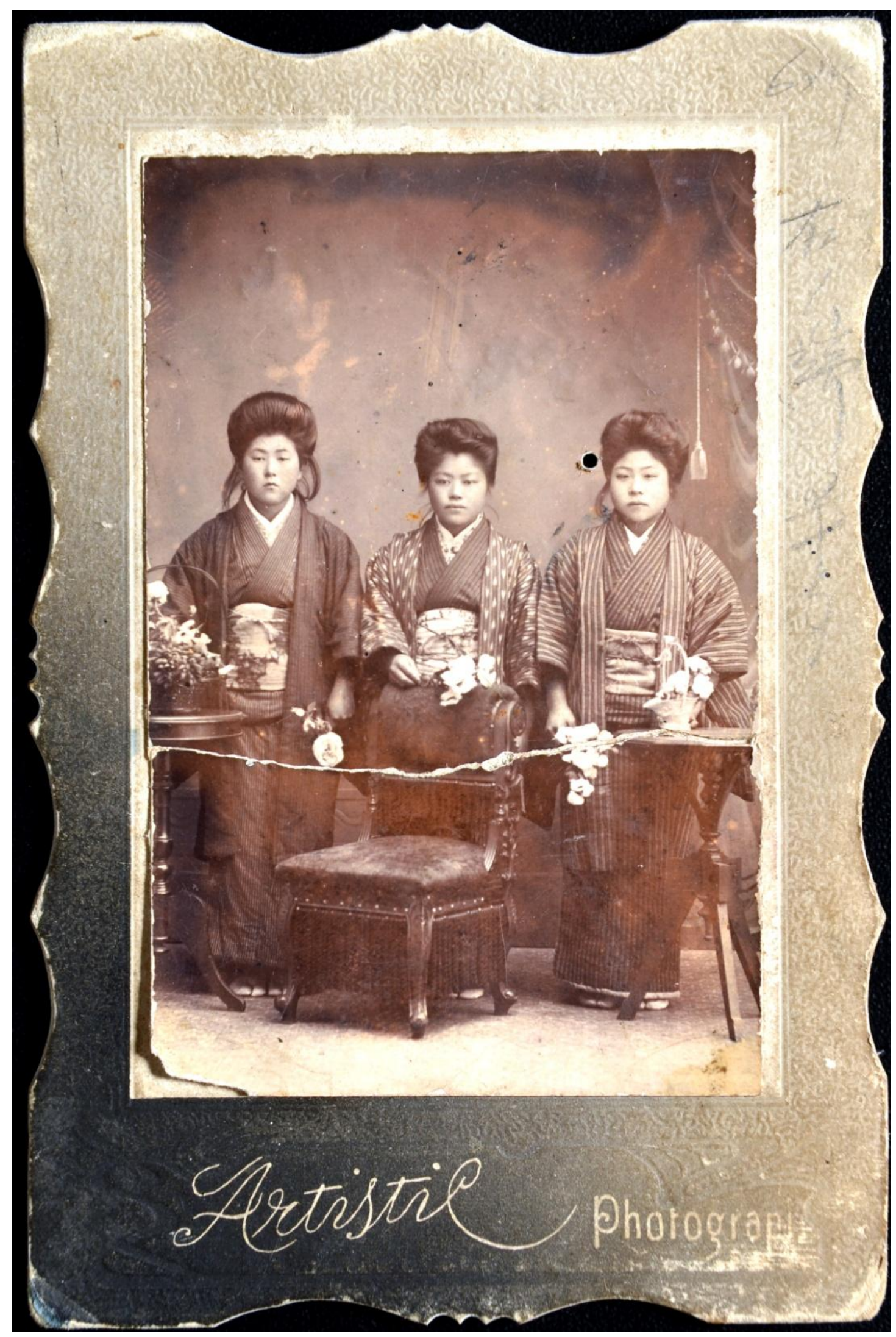

FIGURA 36. Ine Narita e amigas. Kagoshima, Japão. 1907 


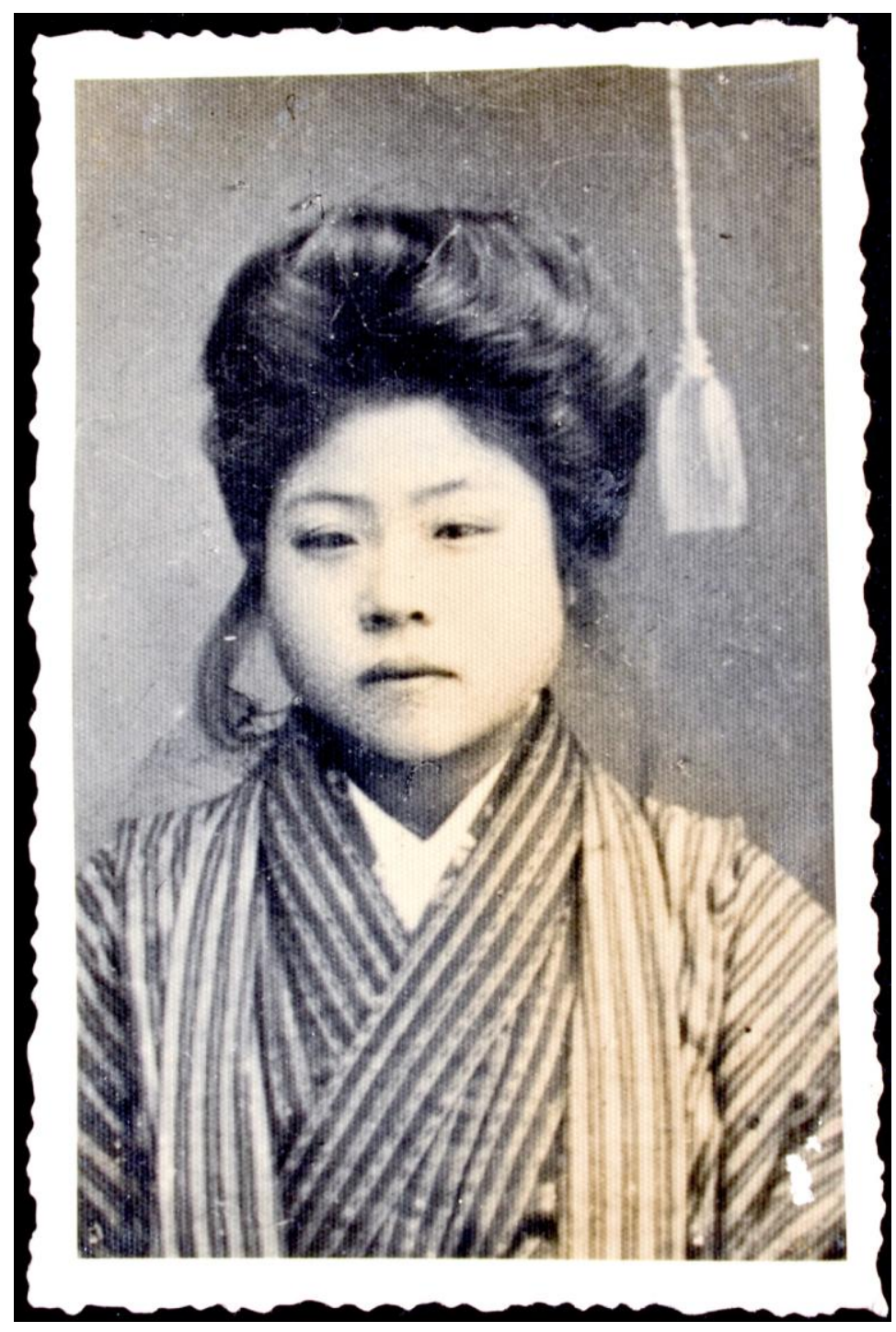

FIGURA 37. Reprodução de retrato de Ine Narita. São Paulo, SP. ca. 1950 


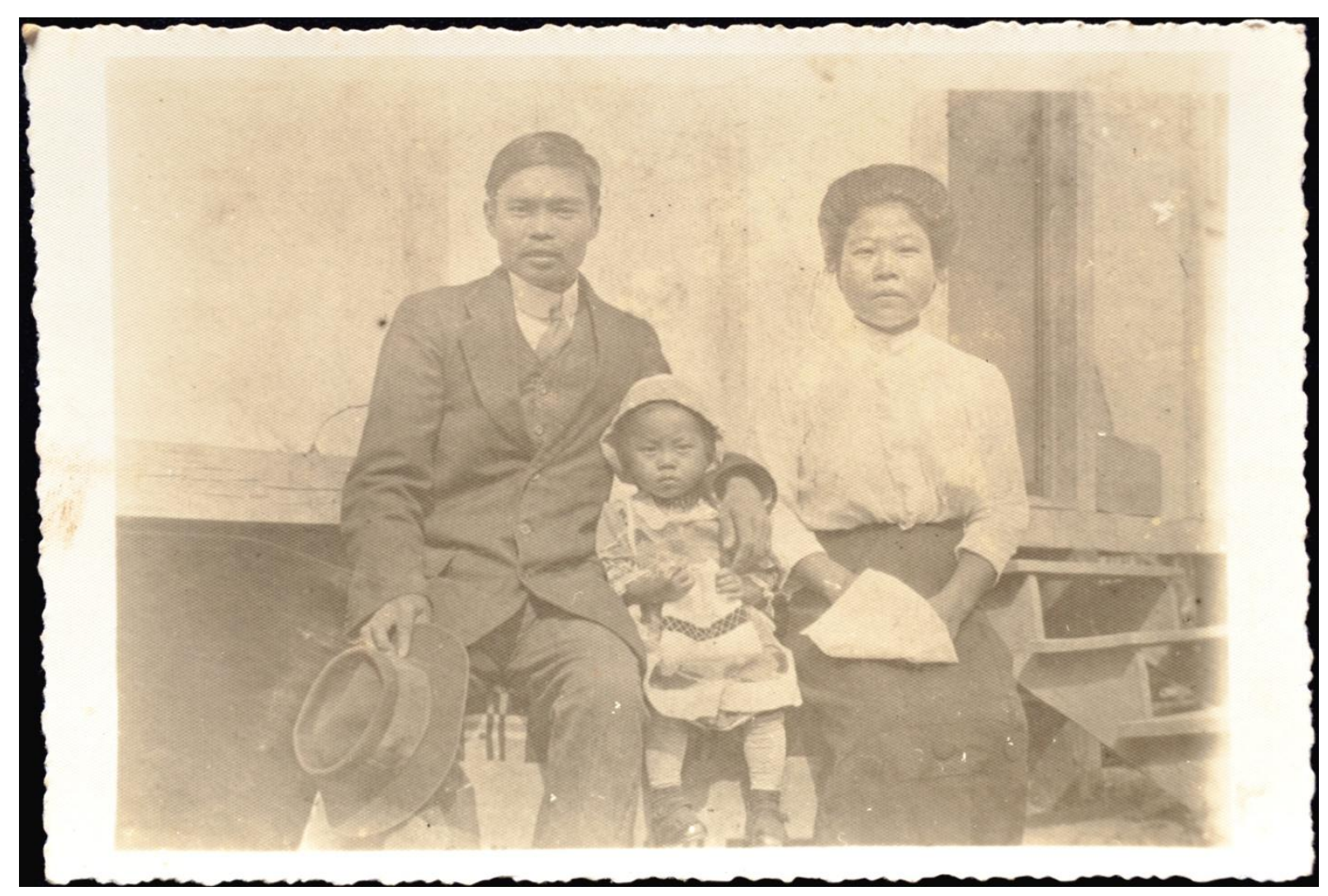

FIGURA 38. Eiji, Ine e Akie Sakasegawa. Iguape, SP. 1916 


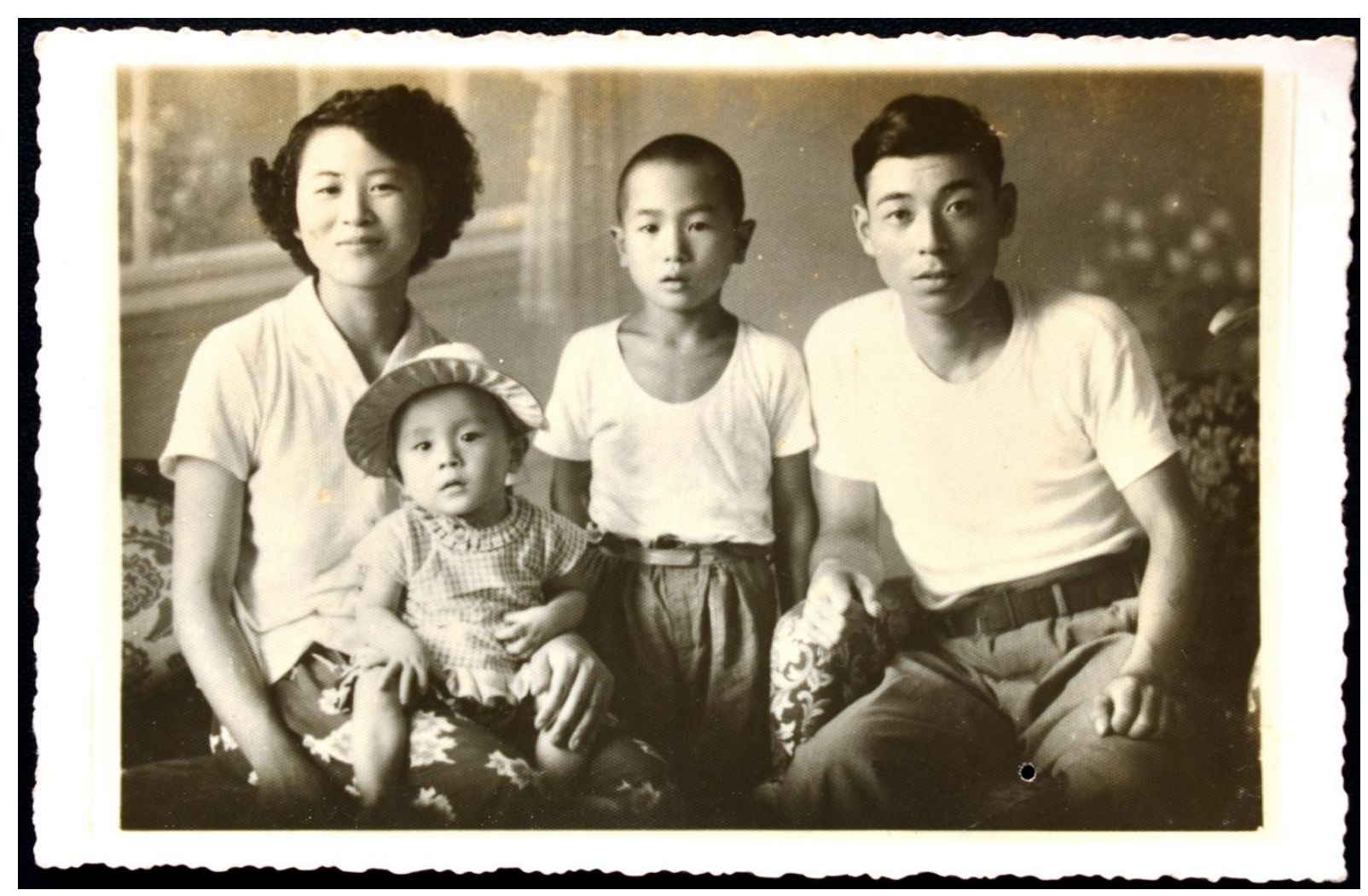

FIGURA 39. Masato Narita e família. Kagoshima, Japão. 1952 


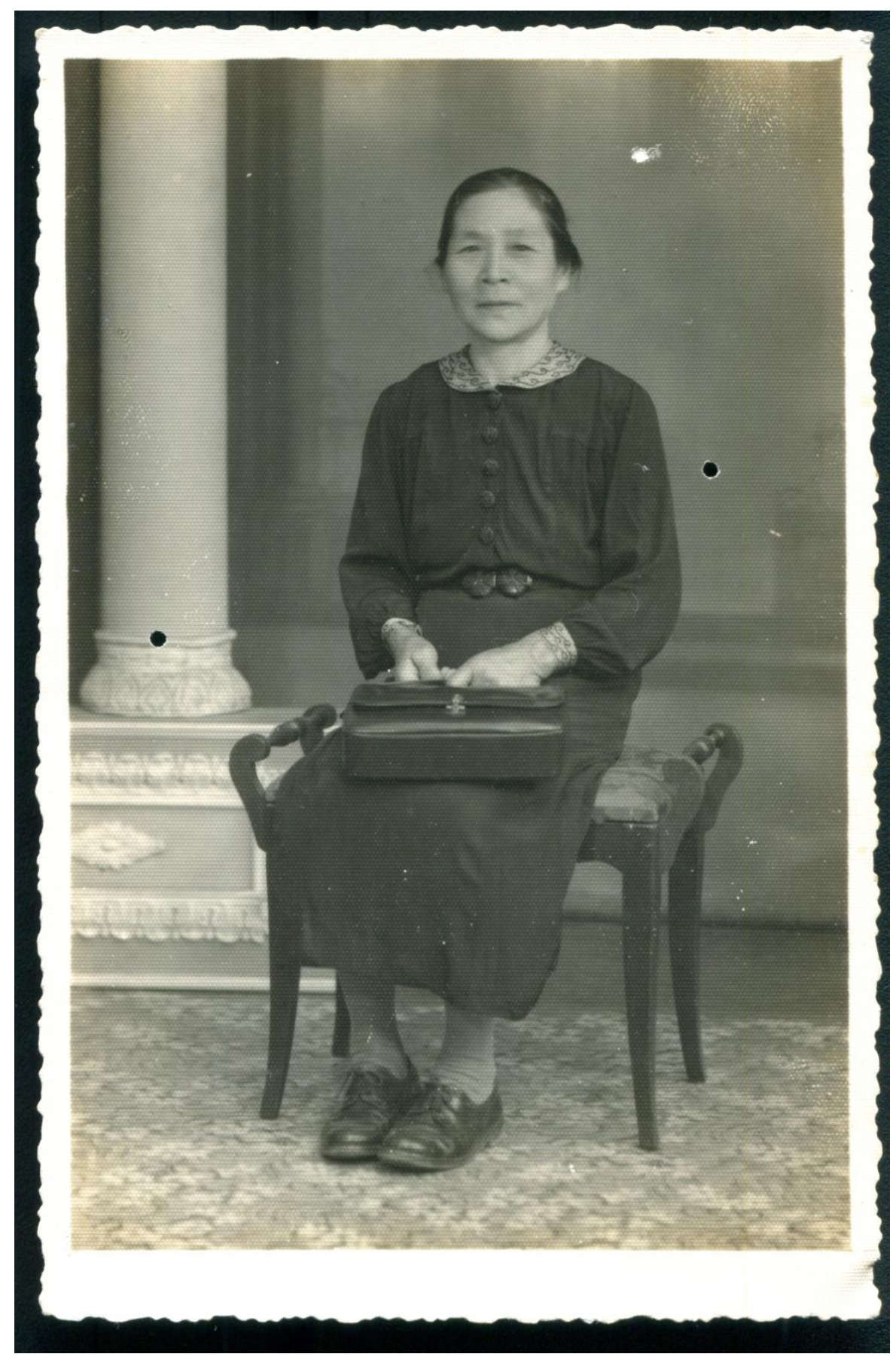

FIGURA 40. Ine Narita Sakasegawa. São Paulo, SP. ca. 1950 


\subsection{As diversas encarnações de uma imagem (estudo de caso)}

No espólio fotográfico de Ine Narita Sakasegawa, há cinco cartes-de-visite, que constituem uma exceção nessa coleção. Não foi possível comprovar se outros imigrantes que chegaram na década de 1910 também possuíam cartes-de-visite. A natureza repetitiva da fotografia leva a crer que sim.

Das cinco imagens, quatro cartes-de-visite foram produzidas no Japão no começo do século XX. São os retratos de Soemon Sakasegawa (pai de Eiji; Figura 35), Kikumori Kijima (primo de Ine, que imigrou para o Brasil no Kasato-maru), duas meninas não identificadas, e de Ine com duas amigas (Figura 36). A outra carte-de-visite foi produzida no Brasil, é um retrato do senhor Namba com uma menina (provavelmente, sua filha) na colônia de Jipovura, onde as duas famílias (Sakasegawa e Namba) foram vizinhas (Nihonjin no Nanbei ni Hattenseshimu, 2008).

Por outro lado, cópias em papel (suporte em gelatina) são muito mais comuns. Uma das primeiras fotos feitas no Brasil do casal Sakasegawa e sua primogênita, Akie, a princípio de suporte em gelatina, foi escolhida para ser impressa diversas vezes, a um custo menor, e, assim, através da monotipia, tornou-se uma carte postale (encontrei uma cópia dessa imagem com diversos netos de Eiji e Ine; Figura 38). As fotos são mais numerosas quando Ine tem mais idade, o que parece evidenciar uma melhora na condição econômica.

Há uma lacuna de nove anos entre a carte-de-visite de 1907 (Figura 36) feita no Japão e o primeiro retrato de família no Brasil de 1916 (Figura 38), o que indica parte do período de acomodação após a chegada ao Brasil. Quatro anos após o desembarque, já com uma filha, pode-se ver a família Sakasegawa um pouco mais próspera. De fato, todos os informantes referiram-se ao tempo em Iguape, onde Eiji teve uma destilaria de cana-deaçúcar, como próspero e feliz. Em 1922, a família vendeu tudo e se mudou para Santos, devido à contínua sucumbência à malária, especialmente de Eiji. 
Essa carte-de-visite foi feita no Japão em 1907, poucos meses antes de Ine completar dezesseis anos. Nesse momento, a carte-de-visite já não era novidade ou moda havia tempo, mesmo no Japão, onde a fotografia chegou alguns anos depois de seu anúncio oficial (1839, Louis-Jacques-Mandé Daguerre e Nicéphore Niépce, na França; 1840, William Henry Fox Talbot, na Inglaterra; meados da década de 1840, no Japão).

Depois de séculos isolado, o Japão se abriu, frente a pressões inglesas e estadunidenses, para o comércio internacional. A era Meiji (1868-1912) foi um período de grande modernização, quando muitas inovações tecnológicas adentraram o país, dentre elas, a fotografia. Pela ruptura que esse período trouxe, muitos costumes antigos conviveram com costumes modernos, sem desaparecer por completo.

O padrão carte-de-visite foi criado por André-Adolphe-Eugène Disdéri, na França, em 1854. Seu suporte, albúmen, barateou o retrato e, por isso, tornou-se mais popular; o daguerreótipo, desde então, é um item de luxo, mas nunca parou de ser produzido. Juntamente com a fotografia estereoscópica, a carte-de-visite teve seu apogeu nas décadas de 1860 e 1880. Na virada do século, o albúmen foi substituído por colódio ou gelatina. Gradualmente, a gelatina se destacou dos outros suportes, por sua facilidade de manuseio e baixos custos.

A carte-de-visite de Ine (Figura 36) possui suporte de gelatina que, colado ao papel cartão, compõe o objeto final. É um retrato de três meninas, uma delas é minha bisavó, as outras duas, não foi possível identificar. Todas estão com roupas japonesas e de penteado tradicional. No entanto, a cortina pintada ao fundo, o mobiliário ou objetos de cena (cadeiras e mesinha de madeira) são tipicamente europeus, o que cria um contraste estranho na imagem. As moças japonesas não parecem à vontade naquele cenário. Ao invés de se sentarem, estão todas de pé, atrás dos móveis de madeira.

O papel cartão foi cortado nas margens de modo a enfatizar a sensação tátil; são espécies de espaços para os dedos se acomodarem. Não fui capaz de encontrar outra carte-de- 
visite com esse corte, nem em bibliografias específicas, nem em museus, nem em acervos online. É um tipo de material que ainda está longe de ter sido esgotado; em muitas coleções particulares, encontram-se formas fotográficas esquecidas.

Pouco abaixo do meio da fotografia, há um amassado irregular, que não se encontra no cartão. Não há como saber se essa imagem estava originalmente colada no cartão, e esse dano foi resultado de uma tentativa de removê-la. Ou se ela estava solta e, por estar se danificando, foi então colada no cartão. Por outro lado, as outras cartes-de-visite não possuem danos na imagem. Havia também duas fotos muito similares a essa em questão, sem cartão, todas com algum tipo de dano físico. Não é possível saber se essas imagens foram descoladas de um cartão ou de um álbum fotográfico. O fato é que todas têm resquícios de descolamento no verso. Impossível saber que tipos de acidentes, involuntários ou não, causaram tais danos.

No verso da carte-de-visite em questão, consta a data em que foi feita, em japonês e em algarismos arábicos (23.01.1907), além do nome de Ine, em japonês. Seu nome de família, na época, ainda solteira, é Narita. No entanto, não estão escritos os nomes das duas outras meninas, que suponho terem sido amigas de minha bisavó. Não pude precisar quem escreveu essas informações no verso do cartão, mas devem ter sido escritos muito tempo depois da foto ter sido tirada. A ausência dos outros nomes pode indicar: familiaridade (Ine sabia o nome de suas amigas, portanto, não precisaria escrevê-los) ou simples ignorância (nenhum de seus filhos ou netos sabia senão o seu nome). Não vejo motivo para ela escrever apenas o próprio nome.

Em uma das entrevistas, o filho caçula de Ine, Toshio, me forneceu as seguintes informações: Ine trouxe essas cartes-de-visite do Japão (como imaginava que sua estadia seria temporária, ela deve ter apanhado alguns retratos de relações mais próximas na época, mas não se preocupou em trazer imagens de todos os parentes e amigos), as meninas que aparecem nas fotos e que não foram identificadas eram amigas, colegas de escola de Ine. 
Durante a Segunda Guerra, a correspondência entre Japão e Brasil teve um hiato. Não era permitido receber cartas do Japão nem escrever em japonês. Aos poucos, as cartas recomeçaram a circular no pós-guerra. Nesse período, segundo Toshio, um sobrinho de Ine enviou um retrato de si e um retrato com sua mulher e filhos (Figura 39).

Para retribuir, Ine quis enviar alguns retratos daqui. Ela encomendou um retrato em um estúdio professional, Foto Ueno, no Largo de Pinheiros (Figura 40). Também foram feitas duas reproduções de fotos existentes, uma 3 x 4 de Eiji, que já havia falecido, e um recorte da carte-de-visite de Ine (Figura 37).

A reprodução retira as duas desconhecidas da imagem, assim como o estranho mobiliário europeu. O corte, na verdade, remove da imagem o que havia de idiossincrático, deixando apenas um detalhe fora de lugar (puxador de cortina, no canto superior direito). $\mathrm{O}$ conflito cultural é apagado e as antigas relações de amizade, provavelmente perdidas após a migração, subtraídas do quadro.

Nessa reprodução, o aspecto tátil fica mais sutil, porém não desaparece. As bordas foram cortadas por uma tesoura de corte irregular, processo comum em fotos de família do período (meados do século XX). Os tons de sépia da imagem original ficaram esmaecidos na reprodução, restando principalmente tons de cinza, com algum pigmento amarelo. Essa iniciativa particular de conservação não é rara de ser encontrada dentro de coleções fotográficas de imigrantes. Certas imagens (de antepassados, por exemplo) recebem atenção especial e escapam à deterioração por meio de uma cópia nova.

Na década de 1950, Ine era uma senhora de sessenta anos, seus filhos estavam crescidos e a maioria casada. Seu marido faleceu em 1952. A carta do sobrinho que não conheceu pessoalmente trouxe uma prazerosa obrigação: apresentar-se, ou seja, retratar-se. Quando Ine atualiza um retrato de sua juventude, escolhe aquele onde sua aparência mais a agrada: jovem, com marcas de sua origem nipônica. Essa escolha de se apresentar como havia 
sido indica uma necessidade de assumir um vínculo com o Japão, que a imigração, no foro, não poderia romper.

No entanto, ela enviou também um retrato atual de si, no Brasil, com sessenta anos. Na velhice, Ine não pensava mais em retornar à terra natal; sua vida havia transcorrido em outra terra, que, conforme os filhos e netos foram nascendo, foi se tornando familiar e querida. A escolha dos dois retratos, tão distantes no tempo, um da juventude no Japão, outro da maturidade no Brasil, demonstra uma identidade que não era exclusivamente japonesa nem brasileira. Esses dois lados complementares indicam uma negociação identitária muito bem explicada por Jeffrey Lesser (2001) e que se exprime como uma nacionalidade nipo-brasileira, marcada pela necessidade de não optar por apenas um lado, a herança japonesa ou a realidade brasileira, mas por aceitar a multiplicidade.

A correspondência com um sobrinho reafirma o laço com o país natal. E, nessas circunstâncias, os retratos servem para enfatizar esses laços. Isso corrobora as afirmações de que, para os issei ou imigrantes, "o grupo de referência são os parentes e amigos no Japão" e “os valores básicos internalizados são japoneses, enquanto as atitudes exteriores crescentemente tornam-se americanizadas" (CONNOR, 1977, p. 297-8).

O percurso de um retrato de Ine mostra como a relação entre retrato e identidade é estreita. A primeira versão da imagem é a carte-de-visite (Figura 36), que foi reproduzida em gelatina, resultando na segunda (Figura 37). Segundo Toshio, essa reprodução ainda serviu de modelo para um retrato pintado do casal Sakasegawa, que não foi encontrado. A última atualização, pelo menos por enquanto, é a reprodução digital para esta apresentação, resultado da pesquisa acadêmica, o que a retira da esfera estritamente familiar para o âmbito público. Além dessa mudança política, a imagem de Ine passou também por algumas mudanças morfológicas: de carte-de-visite para reprodução em gelatina, em seguida, para retrato pintado e fotografia digital. 
A passagem dessa imagem por tantos meios indica sua importância tanto para Ine como para seus filhos, netos, bisnetos e parentes; a transposição para novos meios ou a atualização dessa imagem revela o afeto e o cuidado para que Ine fosse lembrada.

\title{
3.8. Relações de parentesco e amizade
}

Hiroshi Saito é um dos pesquisadores da imigração japonesa no Brasil que acreditam que a família "composta" (mínimo de três pessoas capazes de trabalho, entre 12 e 50 anos política das "três enxadas”) era artificial, “da qual não se poderia esperar relações estáveis entre seus membros nem uma unidade constante como grupo primário em confronto com a família naturalmente formada.” (1961, p. 62)

Por outro lado, Francisca Isabel Schurig Vieira contesta:

\begin{abstract}
Entretanto, não podemos deixar de apontar que a grande maioria dos imigrantes veio em família ou com membros da família (...) Ora, o tipo mesmo da imigração propiciava a manutenção da família como unidade econômica coesa e coletivamente orientada. (VIEIRA, 1973, p. 113)
\end{abstract}

Para os imigrantes, parece haver diversas famílias: família nuclear, família estendida, rede de amizades (na falta de um nome melhor. Os africanos que sobreviveram nas mesmas embarcações para o Brasil formaram uma rede social de amizade, baseada em alguma ideia de família estendida, e, chamavam-se, entre si, malungos, segundo Mary C. Karasch (2000, p. 393) e Jaime Rodrigues (2005, p. 242), ou seja, companheiros de travessia). O fato de terem feito a viagem na mesma embarcação formava entre os imigrantes um elo afetivo mantido após o desembarque, na forma de associações de auxílios mútuos.

No caso da família nuclear, mesmo que o terceiro membro, postiço mesmo, evadisse, o casal acabaria tendo filhos. E, o filho ou a filha adotiva também se casaria e teria filhos. A família estendida envolve parentes no Japão e parentes no Brasil (tendo imigrado juntos ou 
não). A rede de amizades se refere aos amigos de travessia e aos companheiros ou sócios de trabalhos, passados e atuais.

De um contexto bem diferente, uma pesquisadora holandesa observa: "Quaisquer que fossem as distâncias percorridas, os imigrantes não eram subitamente privados de sua cultura tradicional, na verdade, eles a utilizaram efetivamente em seu processo de adaptação.” (JANSSENS, 1993, p. 161)

No Brasil, o processo de adaptação para os imigrantes levou-os a um período de nomadismo. Até acharem seu lugar no novo mundo, a procura por ele era motivada por melhorias econômicas. As constantes mudanças faziam com que a rede de relações sociais fosse frágil. Essa rede social não foi provocada por proximidade ou vizinhanças, mas por uma herança cultural comum. Foi preciso certo empenho, através da correspondência, por exemplo, para que as relações fossem mantidas.

Por um lado, a crescente modernização do Estado de São Paulo foi o que possibilitou que a correspondência fosse mantida (através da rede ferroviária), e, ironicamente, também foi cada vez mais motivo de mudanças de endereço, isto é, novamente, separações. Com a industrialização ascendente, a mobilidade geográfica também aumenta. A família nuclear se cristaliza e a família estendida se mantém através de cartas, fotos, e ocasionais visitas.

Além das relações familiares, baseadas em laços de sangue, as relações sociais dos imigrantes japoneses se estabeleceram em torno de conterrâneos (pessoas que haviam nascido nas mesmas províncias ou cidades no Japão) e de companheiros de travessia (pessoas que vieram nas mesmas embarcações ao Brasil).

\subsection{Construção e reconstrução de memórias}

No instante em que as cartas eram escritas e as fotografias eram produzidas, os motivos familiares não envolviam a ideia de permanência ou continuidade histórica. Esses 
materiais foram confeccionados para usufruto imediato, ou seja, foram feitos para as pessoas vivas naquele momento. Esses objetos de memória, na visão de quem os fez, serviam apenas para os próprios fins.

A noção de que esses materiais simples e domésticos pudessem ter importância histórica é recente e ainda não muito difundida. Os imigrantes e seus filhos tinham humildade em demasia para acreditar que suas cartas e fotos poderiam suscitar interesses fora da esfera familiar. De fato, esses materiais eram tão pessoais e íntimos que mesmo os netos foram privados de uma fruição na forma de transmissão oral.

Jamais poderiam eles imaginar que suas cartas e fotos um dia seriam objeto de uma dissertação acadêmica. Minha mãe e suas irmãs chegaram a se espantar quando viram as fotos de sua mãe e avó em meios acadêmicos, como congressos e artigos. Eu mesmo acho incrível o quão longe esse material me levou. Afinal, minha viagem ao Japão foi possível por conta de minha pesquisa de mestrado. Chega a ser estranho que as cartas e as fotos de minha família me levaram de volta à cidade natal de meus antepassados.

Na visão dos imigrantes de minha família, parece que o consenso era que o passado ao passado pertencia. Mas talvez esse tipo de atitude, isto é, completa imersão na sobrevivência diária, seja um atributo dos imigrantes em geral, além de ser característica de uma determinada faixa etária. “A idade adulta é norteada pela ação presente: e quando se volta para o passado é para buscar nele o que se relaciona com suas preocupações atuais.” (BOSI, 1998, p. 76)

Mas, para os imigrantes e seus filhos, a luta por um futuro mais confortável economicamente era premente. A necessidade de pertencer à sociedade receptora, e a ela adaptar-se, fez com que atividades subjetivas e emocionais como as reminiscências fossem vistas sem importância e, portanto, supérfluas. 
Devo relembrar que as histórias que pretendi retratar aqui são reinterpretações das histórias de vida de meus antepassados maternos. Assim, apesar de ter podido contar com diversos materiais, informantes e pesquisadores, a responsabilidade pelas escolhas interpretativas repousa unicamente em minhas costas. É uma visão parcial e pessoal sobre os eventos e sentimentos compartilhados através de fotografias e cartas.

É uma visão especialmente parcial porque se refere aos meus antepassados, à minha família. Um pouco de distanciamento parecia possível, pois, de todas as pessoas cujas vidas são abordadas no estudo, conheci apenas minha avó, Akie. No entanto, ao contrário do que preza o bom senso crítico, o objetivo desta pesquisa não foi me distanciar dos objetos de estudo. Pelo contrário, minha intenção era me aproximar de meus antepassados, e aprofundarme em suas histórias através dos fragmentos deixados por eles.

Os parentes se afastando e morrendo, as testemunhas desaparecendo, a imagem empalidece, as lacunas crescem. (...) Traços novos afloram, outros se apagam conforme as condições da vida presente, dos julgamentos que somos capazes de fazer sobre seu tempo. Nos velhos retratos, o impacto da figura viva vai-se apagando, ou vai sendo avivada, retocada. (BOSI, 1998, p. 426)

Espero, com este trabalho, ter conseguido preservar um pouco as memórias de meus avós e bisavós maternos, numa tentativa de lutar contra as forças dispersivas e inexoráveis do tempo.

Cabe a nós, enquanto vivos, continuar a olhar e estimar suas fotografias, contar suas histórias, amar suas pessoas e agradecer por seus esforços. 


\section{Considerações finais}

Uma das dificuldades que encontrei ao realizar este estudo foi a falta de parâmetros sobre os quais pudesse me apoiar. Faltam pesquisas semelhantes para servir de guias, faltam bastantes pesquisas no campo da fotografia. De todo modo, existem muitas variáveis que fazem com que as pesquisas em fotografia vernacular sejam extremamente específicas. $\mathrm{O}$ material fotográfico e as relações com os colaboradores, por exemplo, são suficientes para alimentar diversos trabalhos diferentes.

Não obstante, utilizei uma série de pesquisas que, mesmo não diretamente, se relacionam com os meus temas. Além dos volumes já citados, gostaria de agora nomear outros também consultados.

Sobre a imigração japonesa no Brasil, existem alguns estudos, em sua maioria, quantitativos, dentre os quais, merecem destaque: Cardoso (1972), Cem anos da imigração japonesa no Brasil através de fotografias (2008), Fujii e Smith (1959), Nogueira (1984), Saito (1961), Saito e Maeyama (1973), Saraki (s/d) e Suzuki (1969).

Também existem alguns estudos sobre fotografias vernaculares em diversos países, tais como: Geffroy (1990), Goulart e Mendes (2007), Kasher (2008), Kenyon (1992), Kim (2003), Pinney (1997), Pols (2002), Silber (1973) e Strassler (2010).

Sobre fotografia de família, destacam-se as seguintes publicações: Garat (1994), Julia Hirsch (1981), Marianne Hirsch (1997; 1999), Kuhn (1995), Lesy (1980), Levine e Snyder (2006) e Marcondes de Moura (1983).

E, alguns estudos sobre a história e a arte fotográfica no Japão: A century of Japanese photography (1980), Banta e Taylor (1988), Bennett (2006), Boyd e Izakura (2000), Dobson (2004), Morris (2009), Shimizu (1990), The advent of photography in Japan (1997), Worswick (1980) e Yoakemae (2011). 
Apesar de mais amplos, destaco ainda os estudos clássicos sobre a memória de Bergson (1997), Halbwachs (1997), Ricœur (2000), e um mais recente de Maluf(1995).

Por outro lado, há um estudo que muito se aproxima deste: Turning leaves, de Richard Chalfen (1991) e ele foi bastante utilizado. Outra publicação semelhante que destaco apenas agora é The Japanese American family album, de Hoobler e Hoobler (1996). Por seu aspecto panorâmico, composta por fotos de famílias japonesas que migraram para os EstadosUnidos e por depoimentos esparsos, ela pôde servir apenas como termo de comparação. No entanto, sua mera existência aponta para o interesse que o assunto vem despertando em meios leigos.

Engraçado que essa pesquisa me fez conhecer melhor minha própria família. Visitei diversos parentes que havia visto poucas e esparsas vezes, em ocasiões onde havia pouco espaço para trocas interpessoais (velórios e enterros sendo os mais comuns). Meu trabalho também despertou interesse em alguns de meus primos da família Matsuyama, eles também netos de imigrantes (sansei), tanto pela história pouco conhecida dos imigrantes de nossa família (Eiji e Ine Sakasegawa e, principalmente, Hideo Matsuyama), quanto pelo desejo que essa história possa ser contada às próximas gerações. Assim, minha pesquisa pode servir a diferentes círculos, além do acadêmico (como uma contribuição aos estudos de imigração japonesa no Brasil), também o familiar.

Minha experiência foi radicalmente diferente da de José Yamashiro (1996). Nada estranho, pois somos de gerações diferentes. Também foi diferente da de Akemi Kikumura (1991). Não conheci frieza ou desconfiança por parte de minha família recém-reencontrada no Japão. Muito pelo contrário, fomos capazes de reestabelecer laços de família. Assim, novamente, a individualidade das experiências faz com que as pesquisas tenham seu grau de especificidade. 
Além das fotos e cartas, existem outros objetos pessoais no espólio de Hideo e Akie, como as ferramentas de construção (esquadro, martelo e serrote) de Hideo e os livros, as louças, as roupas e a máquina de costura de Akie. Apesar de fugir do escopo desta pesquisa, esses itens também podem fornecer informações sobre a vida doméstica do casal e dos imigrantes. Schapochnik (1998), em seu artigo sobre fotos de família, se detém sobre outros objetos que compõem o ambiente doméstico e analisa alguns cômodos da casa. Kouwenhoven (1982), ao discorrer sobre a diversidade da arte vernacular, aponta para a infinidade de objetos vernaculares. $\mathrm{O}$ espaço vernacular é rico em artefatos que possuem significados para a vida em família. Desse modo, esses objetos domésticos podem ser úteis para investigar a história da intimidade. No entanto, essa história apresenta certas dificuldades ao pesquisador na medida em que as famílias estimam e guardam consigo esses objetos carregados de afetividade e histórias.

Ao longo do trabalho, algumas pessoas muito importantes tanto para mim quanto para este estudo faleceram. Gostaria de reiterar aqui minha gratidão por seu legado e amor. Logo no início da pesquisa, minha avó materna, Akie Sakasegawa Matsuyama, faleceu. Durante o período de trabalho, faleceram Tsuyako Tomita Okazaki e Maria Hisatsugui Kurita. Próximo do final da pesquisa, faleceu minha avó paterna, Kikue Hirata Hisatsugui.

Se tivesse começado minha pesquisa há mais tempo, poderia ter contado com os relatos e as memórias de Akie de modo direto. Isso não é necessariamente um arrependimento, apenas uma constatação de que o tempo de uma geração está em seu término. Se não pude começar meu estudo antes e, assim, perdi conhecimentos que se foram com as pessoas que os guardavam, por outro lado, quanto mais o tempo passa, menores são as chances de se compreender essas histórias.

Se esta pesquisa tivesse sido realizada em qualquer outro momento, os resultados seriam perceptivelmente diferentes. Procurei, ao longo do texto, deixar claros os processos 
pelos quais ele foi composto, na tentativa de mostrar o quão localizado e parcial, ele, de fato, é. 


\section{Bibliografia}

A century of Japanese photography. Japan Photographer's Association. Introduction by John W. Dower. New York: Pantheon Books, 1980.

African American Vernacular Photography: selections from the Daniel Cowin collection. Essays by Brian Wallis and Deborah Willis. Göttingen and New York: Steidl and International Center of Photography, 2005.

ALLEN, James; ALS, Hilton; LEWIS, Congressman John; LITWACK, Leon F. Without sanctuary: lynching photography in America. Santa Fe, NM: Twin Palms Publishers, 2008.

ARAMASA, Taku. A portrait of Japanese immigrants to South America. Tokyo: Dai Nippon Printing Co., Ltd., 1985.

ARAÚJO, Íris Morais. Militão Augusto de Azevedo: fotografia, história e antropologia. São Paulo: Alameda, 2010.

ARIÈS, Philippe. Les images de la famille. In: l'Ancien Régime. Paris: Éditions du Seuil, 1973.

BANTA, Melissa and TAYLOR, Susan (eds.). A timely encounter, nineteenth-century photographs of Japan: an exhibition of photographs from the collections of the Peabody Museum of Archaeology and Ethnology and the Wellesley College Museum. Cambridge, MA and Wellesley, MA: Peabody Museum Press and Wellesley College Museum, 1988.

BARNLUND, Dean C. Public and private self in Japan and the United States: communicative styles of two cultures. Tokyo: The Simul Press, Inc., 1975.

BARTHES, Roland. A câmara clara: nota sobre a fotografia. Tradução: Júlio Castañon Guimarães. Rio de Janeiro: Nova Fronteira, 1984.

BATCHEN, Geoffrey. Vernacular photographies. In: —_. Each wild idea: writing photography history. Cambridge: The Massachusetts Institute of Technology Press, 2001.

. Forget me not: photography and remembrance. Amsterdam and New York: Van Gogh Museum and Princeton Architectural Press, 2004.

Suspending time: life - photography - death. With essays by Yoshiaki Kai and Masashi Kohara. Shizuoka and Tokyo: Izu Photo Museum and Nohara Co., Ltd., 2010.

BATCHEN, Geoffrey (ed.). Photography degree zero: reflections on Roland Barthes's Camera Lucida. Cambridge: The Massachusetts Institute of Technology Press, 2009.

BENJAMIN, Walter. A obra de arte na era de sua reprodutibilidade técnica. In: Magia e técnica, arte e política: ensaios sobre literatura e história da cultura. Tradução: Sérgio Paulo Rouanet. Prefácio: Jeanne Marie Gagnebin. 7. ed. São Paulo: Brasiliense, 1994. 
BENNETT, Terry. Photography in Japan 1853-1912. Tokyo, North Clarendon, VT, Singapore: Tuttle Publishing, 2006.

BERGSON, Henri. Matière et mémoire: essai sur la relation du corps à l'esprit. 5. ed. Paris: Presses Universitaires de France, 1997.

BOOTH, William James. Communities of memory: on witness, identity, and justice. Ithaca and London: Cornell University Press, 2006.

BOSI, Ecléa. Memória e sociedade: lembranças de velhos. 6. ed. São Paulo: Companhia das Letras, 1998.

BOTT, Elizabeth. Family and social network: roles, norms and external relationships in ordinary urban families. Preface by Max Gluckman. 2. ed. London: Tavistock Publications, 1971.

BOUQUET, Mary. Making kinship, with an old reproductive technology. In: FRANKLIN, Sarah \& MCKINNON, Susan (eds.). Relative values: reconfiguring kinship studies. Durham \& London: Duke University Press, 2001.

BOURDIEU, Pierre et alli. Un art moyen: essai sur les usages sociaux de la photographie. 2. ed. Paris: Les éditions de minuit, 1965.

BOUREAU, Alain et alli. La correspondance: les usages de la lettre au XIXe siècle. Paris: Fayard, 1991.

BOYD, Torin and IZAKURA, Naomi. Portraits in sepia: from the Japanese carte de visite collection of Torin Boyd and Naomi Izakura. Tokyo: Asahi Sonorama, 2000.

CADAVA, Eduardo and CORTÉS-ROCCA, Paola. Notes on love and photography. In: BATCHEN, Geoffrey (ed.). Photography degree zero: reflections on Roland Barthes's Camera Lucida. Cambridge: The Massachusetts Institute of Technology Press, 2009.

CAMERON, Wendy; HAINES, Sheila; MAUDE, Mary McDougall (eds.). English immigrant voices: labourers' letters from Upper Canada in the 1830s. Montreal \& Kingston, London, Ithaca: McGill-Queen’s University Press, 2000.

CARDOSO, Ruth Corrêa Leite. Estrutura familiar e mobilidade social: estudo dos japoneses no Estado de São Paulo. Tese de doutorado - Faculdade de Filosofia, Letras e Ciências Humanas, Universidade de São Paulo. São Paulo, 1972.

CAUGHEY, John L. Negotiating cultures \& identities: life history issues, methods, and readings. Lincoln: University of Nebraska Press, 2006.

Cem Anos da Imigração Japonesa no Brasil através de Fotografias. História dos 100 Anos da Imigração Japonesa no Brasil - Suplemento. Museu Histórico da Imigração Japonesa no Brasil, Associação para Comemoração do Centenário da Imigração Japonesa no Brasil Comissão da Compilação da Historiografia dos 100 anos da Imigração Japonesa no Brasil. Tokyo: Fukyosha, 2008. 
CHALFEN, Richard. Turning leaves: the photograph collections of two Japanese American families. Albuquerque: University of New Mexico Press, 1991.

- Snapshot versions of life. Bowling Green, OH: Bowling Green State University Popular Press, 1987.

COE, Brian and GATES, Paul. The snapshot photograph: the rise of popular photography, 1888-1939. London: Ash \& Grant, 1977.

CONNOR, John W. Tradition and change in three generations of Japanese Americans. Chicago: Nelson-Hall Inc., 1977.

CONWAY, Martin A. and RUBIN, David C. The structure of autobiographical memory. In: COLLINS, Alan F., GATHERCOLE, Susan E., CONWAY, Martin A., MORRIS, Peter E. (eds.). Theories of memory. Hove and Hillsdale: Lawrence Erlbaum Associates, 1993.

CUTSHAW, Stacey McCarroll and BARRETT, Ross. In the vernacular: photography of the everyday. With essays by Bernard L. Herman and Daile Kaplan. Boston: Boston University Art Gallery, 2008.

DAUPHIN, Cécile; LEBRUN-PÉZERAT, Pierrette; POUBLAN, Danièle. Ces bonnes lettres: une correspondance familiale au XIXe siècle. Préface de Roger Chartier. Paris: Albin Michel, 1995.

DAVIES, Charlotte Aull. Reflexive ethnography: a guide to researching selves and others. 2. ed. London and New York: Routledge, 2008.

DEMARTINI, Zeila de Brito Fabri. Relatos orais de famílias de imigrantes japoneses: elementos para a história da educação brasileira. Educação \& Sociedade, ano XXI, no. 72, Agosto de 2000. Disponível em http://www.scielo.br/pdf/es/v21n72/4193.pdf Acesso em 19.02.2011

DENNETT, Terry. Popular photography and labour albums. In: SPENCE, Jo and HOLLAND, Patricia (eds.). Family snaps: the meanings of domestic photography. London: Virago, 1991.

DOBSON, Sebastian et alli. Art \& artifice: Japanese photographs of the Meiji Era. Selections from the Jean S. and Frederic A. Sharf collection. Boston: Museum of Fine Arts, 2004.

DODIER, Virginia. Clementina, Lady Hawarden: studies from life 1857-1864. Introduction by Marina Warner. Afterword by Mark Haworth-Booth. New York: Aperture Foundation, Inc., 1999.

DOI, Takeo. The anatomy of dependence. Translated by John Bester. Tokyo, New York \& San Francisco: Kodansha International Ltd., 1973.

EDWARDS, Elizabeth. Raw histories: photographs, anthropology and museums. Oxford and New York: Berg Publishers Ltd., 2001. 
EDWARDS, Elizabeth (ed.). Anthropology \& Photography 1860 1920. New Haven and London: Yale University Press, 1992.

ERMAKOFF, George. O negro na fotografia brasileira do século XIX. Versão para o inglês: Carlos Luís Brown Scavarda. Rio de Janeiro: George Ermakoff Casa Editorial, 2004.

FABRIS, Annateresa (org.). Fotografia: usos e funções no século XIX. 2. ed. São Paulo: Editora da Universidade de São Paulo, 1998.

FAUSTO, Boris. Imigração: cortes e continuidades. In: NOVAIS, Fernando A. (coord.); SCHWARCZ, Lilia Moritz (org.). História da vida privada no Brasil: contrastes da intimidade contemporânea, vol. 4. São Paulo: Companhia das Letras, 1998.

FOGARASI, Klára. Mounting, matting, passe-partout, presentation. In: HANNAVY, John (ed.). Encyclopedia of nineteenth-century photography. New York and Oxon: Routledge, 2008 .

FRANK, Robin Jaffee. Love \& loss: American portrait and mourning miniatures. New Haven and London: Yale University Press, 2000.

FRIZOT, Michel (ed.). The new history of photography. Köln: Könemann, 1998.

FUJII, Yukio and SMITH, T. Lynn. The acculturation of the Japanese immigrants in Brazil. Gainesville: University of Florida Press, 1959.

GARAT, Anne-Marie. Photos de familles. Paris: Éditions du Seuil, 1994.

GEFFROY, Yannick. Family photographs: a visual heritage. Visual Anthropology, 3: 4, 367409, 1990. Disponível em http://dx.doi.org/10.1080/08949468.1990.9966540 Acesso em 19.02.2011

GOLDIN, Nan; ARMSTRONG, David; HOLZWARTH, Hans Werner (ed.). I $7 l$ be your mirror. Curated by Elisabeth Sussman and David Armstrong. With contributions by James Fenton et alli. New York and Zurich: Whitney Museum of American Art and Scalo, 1996.

GOULART, Paulo Cezar Alves \& MENDES, Ricardo. Noticiário geral da photographia paulistana: 1839-1900. São Paulo: Centro Cultural São Paulo, Imprensa Oficial do Estado de São Paulo, 2007.

GUSTAVSON, Todd. Camera: a history of photography from daguerreotype to digital. New York and London: Sterling Publishing Co., Inc., 2009.

HALBWACHS, Maurice. La mémoire collective. Édition critique établie par Gérard Namer préparée avec la collaboration de Marie Jaisson. Paris: Albin Michel, 1997.

HANDA, Tomoo. O imigrante japonês: história de sua vida no Brasil. São Paulo: Centro de Estudos Nipo-brasileiros, 1987. 
HASSNER, Rune. La fotografía amateur. In: LEMAGNY, Jean-Claude y ROUILLÉ, André (dir.). Historia de la fotografía. Traducción: Fabián García-Prieto. Barcelona: Ediciones Martínez Roca, S.A., 1988.

HEIFERMAN, Marvin et alli. Now is then: snapshots from the Maresca collection. New York and Newark: Princeton Architectural Press and The Newark Museum, 2008.

HILL, Reuben and KÖNIG, René (eds.). Families in East and West: socialization process and kinship ties. Paris: Mouton, 1970.

HIRSCH, Julia. Family photographs: content, meaning and effect. New York: Oxford University Press, 1981.

HIRSCH, Marianne. Family frames: photography, narrative, and postmemory. Cambridge, MA and London: Harvard University Press, 1997.

1999.

(ed.). The familial gaze. Hanover and London: University Press of New England,

HOLLAND, Patricia. Introduction: History, memory and the family album. In: SPENCE, Jo and HOLLAND, Patricia (eds.). Family snaps: the meanings of domestic photography. London: Virago, 1991.

HOOBLER, Dorothy and HOOBLER, Thomas. The Japanese American family album. New York: Oxford University Press, 1996.

IKEDA, Juuji. Kagoshima Kenjinkai Burajiru Ishokumin Shi. São Paulo: Kagoshima Kenjinkai Burajiru Ishokumin Shi Hensanjo, 1941.

JANSSENS, Angélique. Family and social change: the household as a process in an industrializing community. Cambridge, New York and Melbourne: Cambridge University Press, 1993.

KARASCH, Mary C. A vida dos escravos no Rio de Janeiro (1808-1850). Tradução: Pedro Maia Soares. São Paulo: Companhia das Letras, 2000.

KASHER, Steven (org.). America and the tintype. New York and Göttingen: International Center of Photography, Steidl Publishers, 2008.

KENYON, Dave. Inside amateur photography. London: B.T. Batsford Ltd., 1992.

KIKUMURA, Akemi. Promises kept: the life of an issei man. Novato, CA: Chandler and Sharp Publishers, Inc., 1991.

KIM, Yoon Ho. A fotografia como projeto de memória. In: Cadernos de Antropologia e Imagem no 17, Departamento de Ciências Sociais, Instituto de Filosofia e Ciências Humanas, Universidade do Estado do Rio de Janeiro, 2003.

KOSSOY, Boris \& CARNEIRO, Maria Luiza Tucci. O olhar europeu: o negro na iconografia brasileira do século XIX. São Paulo: Editora da Universidade de São Paulo, 2002. 
KOUTSOUKOS, Sandra Sofia Machado. Negros no estúdio do fotógrafo: Brasil, segunda metade do século XIX. Campinas, SP: Editora da Unicamp, 2010.

KOUWENHOVEN, John A. Half a truth is better than none: some unsystematic conjectures about arts, disorder, and American experience. Chicago and London: The University of Chicago Press, 1982.

KUHN, Annette. Family secrets: acts of memory and imagination. London: Verso, 1995.

LANGFORD, Martha. Suspended conversations: the afterlife of memory in photographic albums. Montreal \& Kingston, London, Ithaca: McGill-Queen’s University Press, 2001.

LANGNESS, Lewis. L. and FRANK, Gelya. Lives: an anthropological approach to biography. Novato, CA: Chandler \& Sharp Publishers, Inc., 1981.

LEBRA, Takie Sugiyama and LEBRA, William P. Japanese culture and behavior: selected readings. Revised edition. Honolulu: University of Hawaii Press, 1986.

LEITE, Miriam Moreira. Retratos de família: leitura da fotografia histórica. 3. ed. São Paulo: Editora da Universidade de São Paulo, 2001.

LEJEUNE, Philippe. Photos d'enfance. In: - Pour l'autobiographie: chroniques. Paris: Éditions du Seuil, 1988.

LESSER, Jeffrey. A negociação da identidade nacional: imigrantes, minorias e a luta pela etnicidade no Brasil. Tradução: Patricia de Queiroz Carvalho Zimbres. São Paulo: Editora UNESP, 2001.

LESY, Michael. Time frames: the meaning of family pictures. New York: Pantheon Books, 1980.

LEVINE, Barbara and SNYDER, Stephanie (org.). Snapshot chronicles: inventing the American photo album. New York and Portland, OR: Princeton Architectural Press and The Reed Institute DBA Reed College, 2006.

Lista de bordo do Kasato-maru. Disponível em http://www.arquivoestado.sp.gov.br/kasatomaru.php Acesso em 09.03.2012

MALUF, Marina. Ruídos da memória. São Paulo: Siciliano, 1995.

MANN, Sally. Immediate family. Afterword by Reynolds Price. New York: Aperture Foundation, Inc., 1992.

MARCONDES, Marli. Conservação e Preservação de Coleções Fotográficas. Boletim do Arquivo (São Paulo), Imprensa Oficial SP, v. 1, p. 1-13, 2005. Disponível em http://www.historica.arquivoestado.sp.gov.br/materias/anteriores/edicao01/materia02/conserv acao_de_colecoes.pdf Acesso em 19.02.2011

MARCONDES DE MOURA, Carlos Eugênio (org.). Retratos quase inocentes. São Paulo: Nobel, 1983. 
MORRIS, Rosalind C. (ed.). Photographies East: the camera and its histories in East and Southeast Asia. Durham \& London: Duke University Press, 2009

MULLIGAN, Therese and WOOTERS, David (eds.). Photography from 1839 to today: George Eastman House, Rochester, NY. Köln: Benedikt Taschen, 2000.

Nihonjin no Nanbei ni Hattenseshimu: Nihonjin no Burajiru Ijyû Shibusawa Eiichi. Tôkyo: Kikakuten Zuroku, Shibusawa Shiryoukan, 2008.

NOËL, Françoise. Family life and sociability in Upper and Lower Canada, 1780-1870: a view from diaries and family correspondence. Montreal \& Kingston, London, Ithaca: McGillQueen's University Press, 2003.

NOGUEIRA, Arlinda Rocha. Imigração japonesa na História contemporânea do Brasil. São Paulo: Massao Ohno Editor, 1984.

PINK, Sarah. Doing visual ethnography: images, media and representation in research. London, Thousand Oaks and New Delhi: Sage Publications, 2001.

PINNEY, Christopher. The parallel histories of Anthropology and Photography. In: EDWARDS, Elizabeth (ed.). Anthropology \& Photography 1860 1920. New Haven and London: Yale University Press, 1992.

Camera Indica: the social life of Indian photographs. Chicago and London: The University of Chicago Press and Reaktion Books Ltd, 1997.

Photography and Anthropology. London: Reaktion Books Ltd, 2011.

PINNEY, Christopher and PETERSON, Nicolas (eds.). Photography's other histories. Durham: Duke University Press, 2003.

POLS, Robert. Family photographs 1860-1945. Surrey: Public Record Office Publications, 2002.

PROSSER, Jon (ed.). Image-based research: a sourcebook for qualitative researchers. London and New York: Routledge Falmer, 2003.

REZENDE, Irene Nogueira de. O paraíso e a esperança: vida cotidiana de fazendeiros na Zona da Mata de Minas Gerais (1889-1930). São Paulo: Humanitas, 2004.

RHEM, James. Ralph Eugene Meatyard: the family album of Lucybelle Crater and other figurative photographs. New York: D.A.P./Distributed Art Publishers, Inc., 2002.

RICEEUR, Paul. La mémoire, l'histoire, l'oubli. Paris: Éditions du Seuil, 2000.

RODRIGUES, Jaime. De costa a costa: escravos, marinheiros e intermediários do tráfico negreiro de Angola ao Rio de Janeiro (1780-1860). São Paulo: Companhia das Letras, 2005.

ROSE, Gillian. Visual methodologies: an introduction to the interpretation of visual methods. London, Thousand Oaks and New Delhi: Sage Publications, 2007. 
Doing family photography: the domestic, the public and the politics of sentiment. Farnham, Surrey: Ashgate Publishing Limited, 2010.

ROSENBERGER, Nancy R. (ed.) Japanese sense of self. Cambridge, New York, Melbourne: Cambridge University Press, 1992.

ROUILLÉ, André. La photographie: entre document et art contemporain. Paris: Éditions Gallimard, 2005.

RUBY, Jay. Secure the shadow: death and photography in America. Cambridge: The Massachusetts Institute of Technology Press, 1999.

SAITO, Hiroshi. O japonês no Brasil: estudo de mobilidade e fixação. São Paulo: Sociologia e política, 1961.

SAITO, Hiroshi \& MAEYAMA, Takashi. Assimilação e integração dos japoneses no Brasil. Petrópolis e São Paulo: Vozes e Editora da Universidade de São Paulo, 1973.

SARAKI, John. Japanese emigrants in Brazil: a study of integration of the Japanese people. Rio de Janeiro: SESI, s/d.

SCHAPOCHNIK, Nelson. Cartões-postais, álbuns de família e ícones da intimidade. In: NOVAIS, Fernando A. (coord.); SEVCENKO, Nicolau (org.). História da vida privada no Brasil: da Belle Époque à Era do Rádio, vol. 3. São Paulo: Companhia das Letras, 1998.

SCHERER, Joanna C. The photographic document: photographs as primary data in anthropological enquiry. In: EDWARDS, Elizabeth (ed.). Anthropology \& Photography 1860 1920. New Haven and London: Yale University Press, 1992.

SEKULA, Allan. The body and the archive. In: BOLTON, Richard. (ed.). The contest of meaning: critical histories of photography. Cambridge: The Massachusetts Institute of Technology Press, 1989.

SHIMIZU, Christine. Le Japon du XIXe siècle: la redécouverte. Marseille: Éditions AGEP, 1990.

SILBER, Mark (ed.). The family album: photographs of the 1890s \& 1900s by Gilbert Wight Tilton \& Fred. Boston: David R. Godine, 1973.

SILVA, Armando. Álbum de família: a imagem de nós mesmos. Tradução: Sandra Martha Dolinsk. São Paulo: Editora Senac, Edições SESC SP, 2008.

SIMONDON, Gilbert. Du mode d'existence des objets techniques. Edition augmentée d'une préface de John Hart et d’une postface de Yves Deforge. Paris: Éditions Aubier, 1989.

SONTAG, Susan. On photography. New York: Anchor Books, 1990.

SPENCE, Jo and HOLLAND, Patricia (eds.). Family snaps: the meanings of domestic photography. London: Virago, 1991. 
STEIER, Frederick (ed.). Research and reflexivity. London, Thousand Oaks and New Delhi: Sage Publications, 1991.

STRASSLER, Karen. Refracted visions: popular photography and national modernity in Java. Durham and London: Duke University Press, 2010.

SUZUKI, Teiiti. The Japanese immigrant in Brazil. Tokyo: University of Tokyo Press, 1969.

SZARKOWSKI, John (ed.). Callahan. With an introduction by John Szarkowski. New York: Aperture, Inc. in association with The Museum of Modern Art, 1976.

TAGG, John. The burden of representation: essays on photographies and histories. Amherst: The University of Massachusetts Press, 1988.

Teresa, Revista de Literatura Brasileira, no 8/9. Departamento de Letras Clássicas e Vernáculas. Faculdade de Filosofia, Letras e Ciências Humanas, Universidade de São Paulo. São Paulo: Editora 34, 2008.

The advent of photography in Japan. Tokyo and Hokkaido: Tokyo Metropolitan Museum of Photography and Hakodate Museum of Art, 1997.

TUFTE, Virginia and MYERHOFF, Barbara (eds.). Changing images of the family. New Haven and London: Yale University Press, 1979.

VIEIRA, Francisca Isabel Schurig. O japonês na frente de expansão paulista: o processo de absorção do japonês em Marília. São Paulo: Livraria Pioneira Editora, Editora da Universidade de São Paulo, 1973.

WELLER, Susan C. Structured interviewing and questionnaire construction. In: BERNARD, Harvey Russel (ed.). Handbook of methods in cultural anthropology. London, Thousand Oaks and New Delhi: Sage Publications, 1998.

WICKENS-FELDMAN, Renate. Domestic and family photography. In: HANNAVY, John (ed.). Encyclopedia of nineteenth-century photography. New York and Oxon: Routledge, 2008.

Family Photography. In: WARREN, Lynne (ed.). Encyclopedia of twentieth-century photography. New York and Oxon: Routledge, 2006.

WILLIS, Deborah. Reflections in black: a history of black photographers, 1840-1999. New York and London: W. W. Norton \& Company, 2000.

WORSWICK, Clark (ed.). Japan: photographs 1854-1905. London: Hamish Hamilton, 1980.

YAMASHIRO, José. Trajetória de duas vidas: uma história de imigração e integração. São Paulo: Aliança Cultural Brasil-Japão, Centro de Estudos Nipo-brasileiros, 1996.

YANAGISAKO, Sylvia Junko. Transforming the past: tradition and kinship among Japanese Americans. Stanford, CA: Stanford University Press, 1985. 
Yoakemae: Shirarezaru Nihon Shashin Kaitaku-shi - Shikoku Kyushu Okinawa hen. Tôkyo: Tôkyoto Shashin Bijutsukan, 2011. 


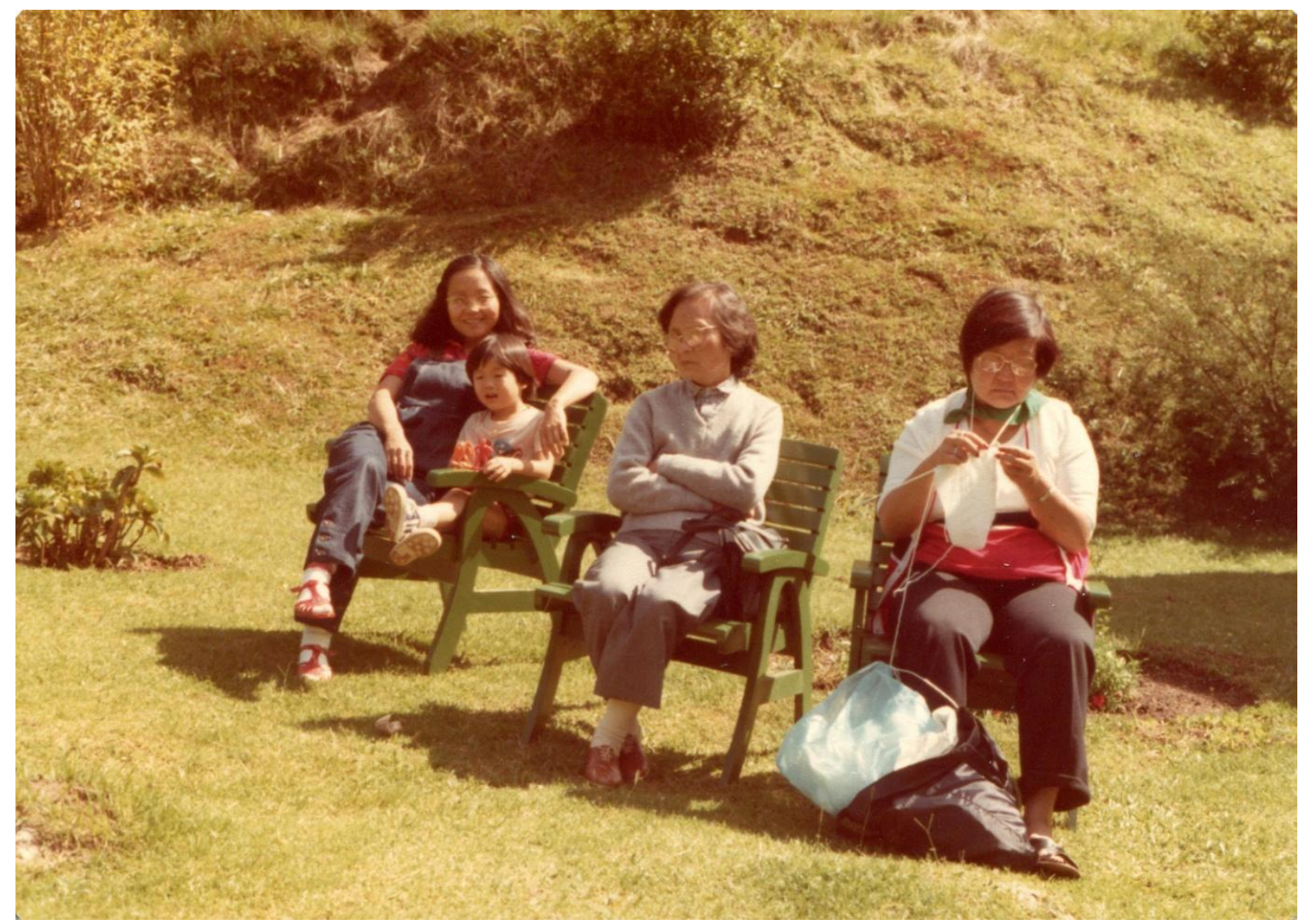

FIGURA 41. Neli, Bruno, Akie e Satiko. Campos do Jordão, SP. 1982/3 


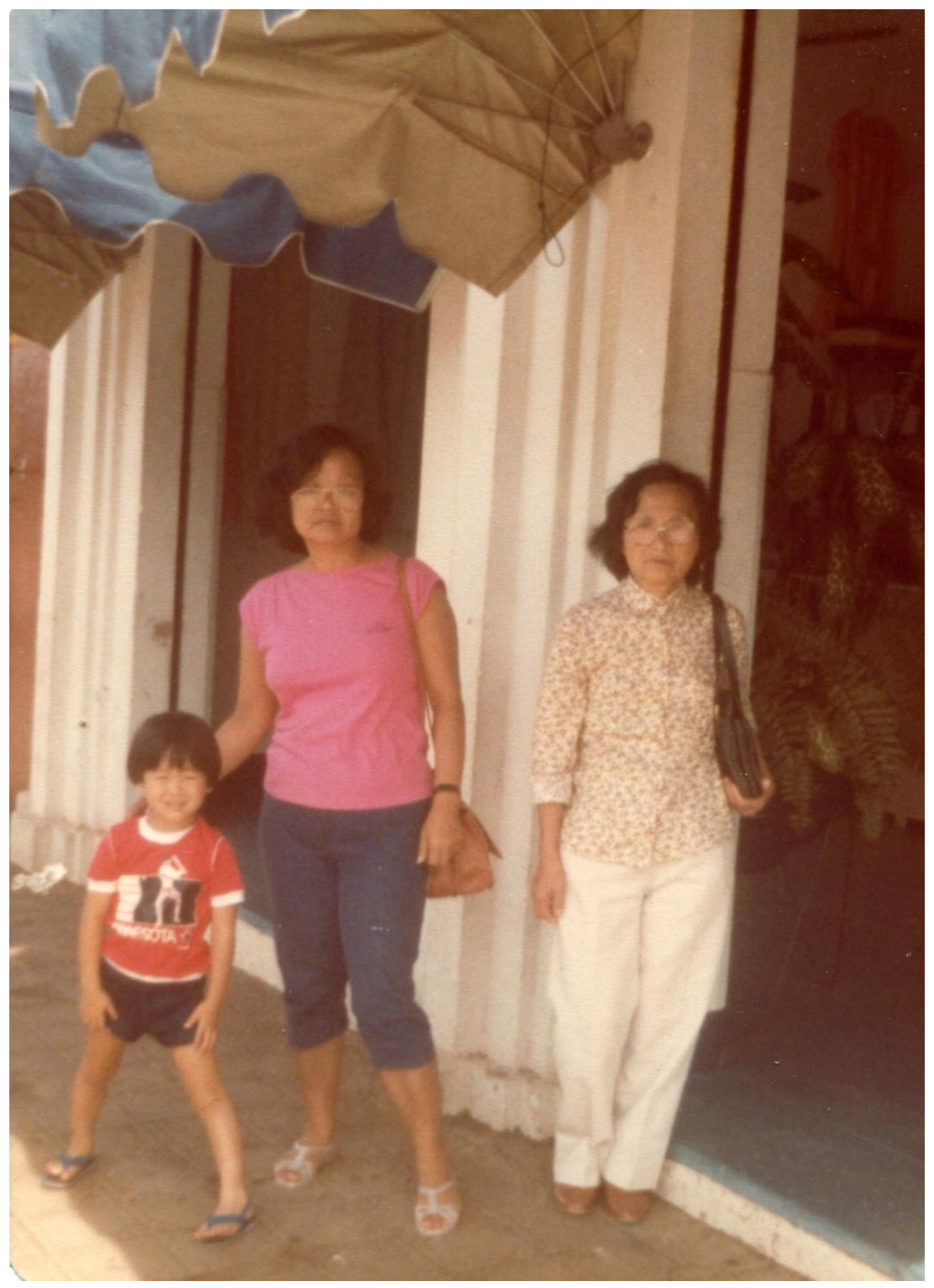

FIGURA 42. Bruno, Luci e Akie. Bariri, SP. 1983 


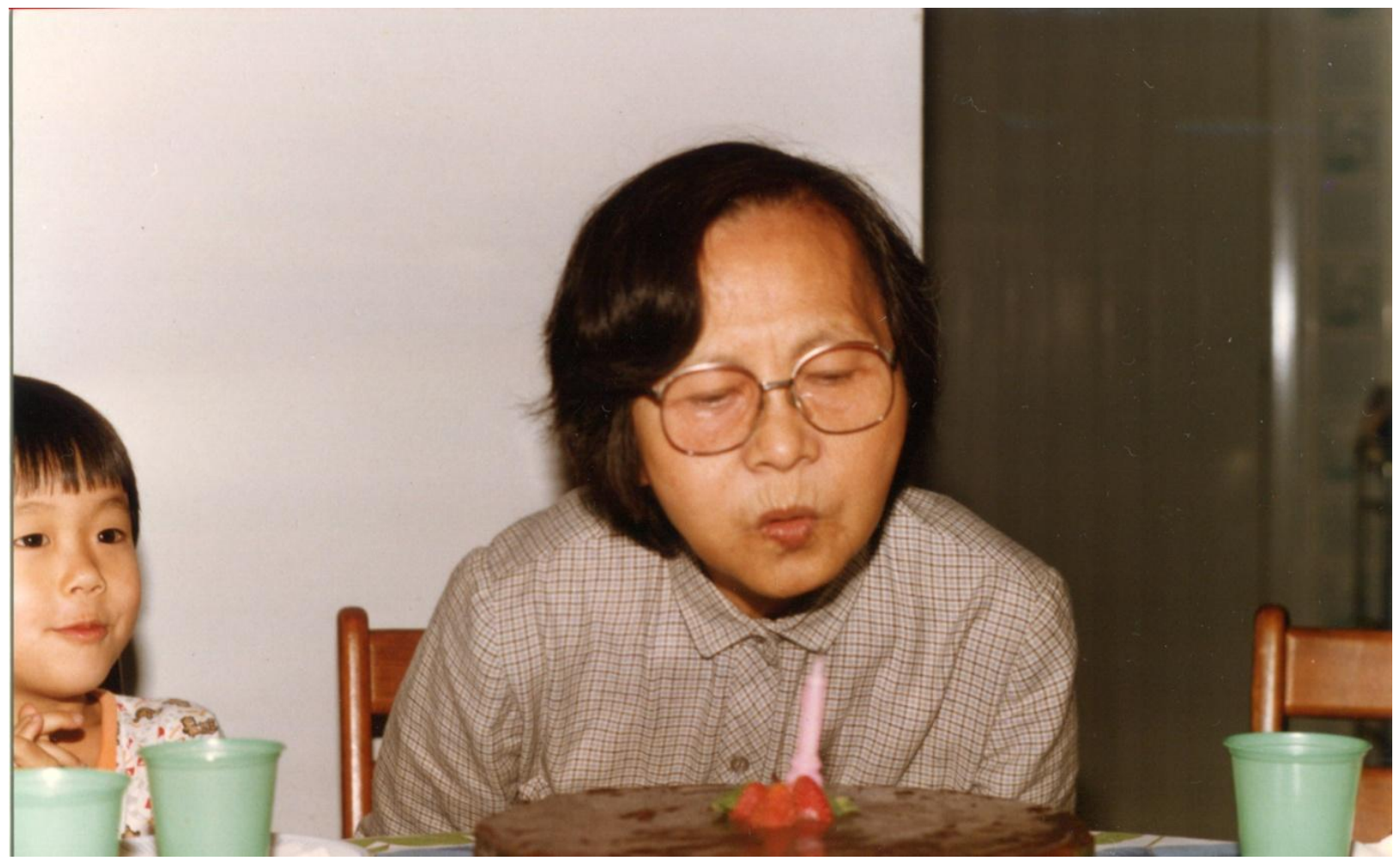

FIGURA 43. Bruno e Akie - aniversário de 70 anos. São Paulo, SP. 1984 


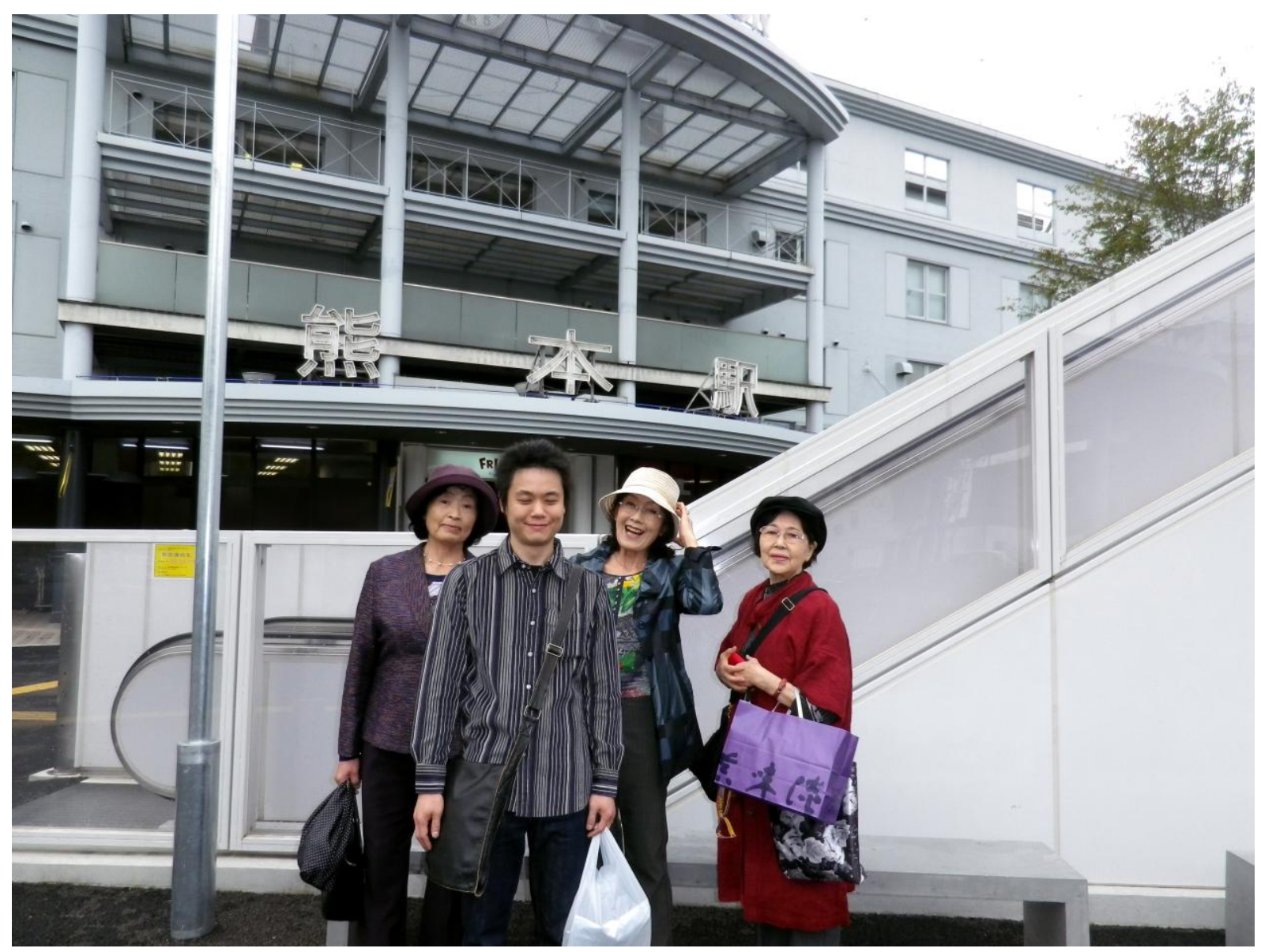

FIGURA 44. Ichiko, Bruno, Hisako e Fuyoko. Kumamoto, Japão. 2011 


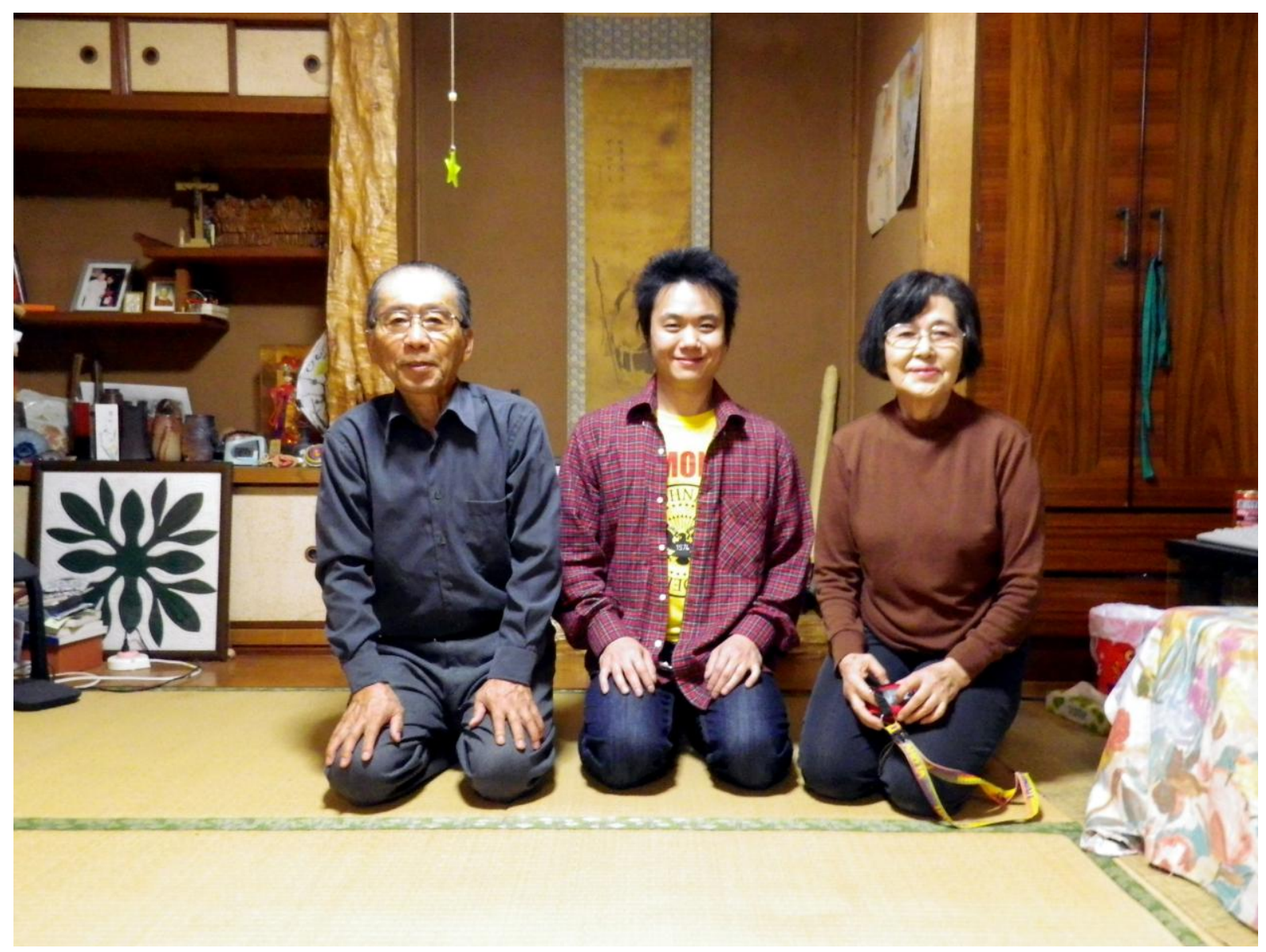

FIGURA 45. Norio, Bruno e Fuyoko na casa da família Shinmyozu. Kagoshima, Japão. 2011 


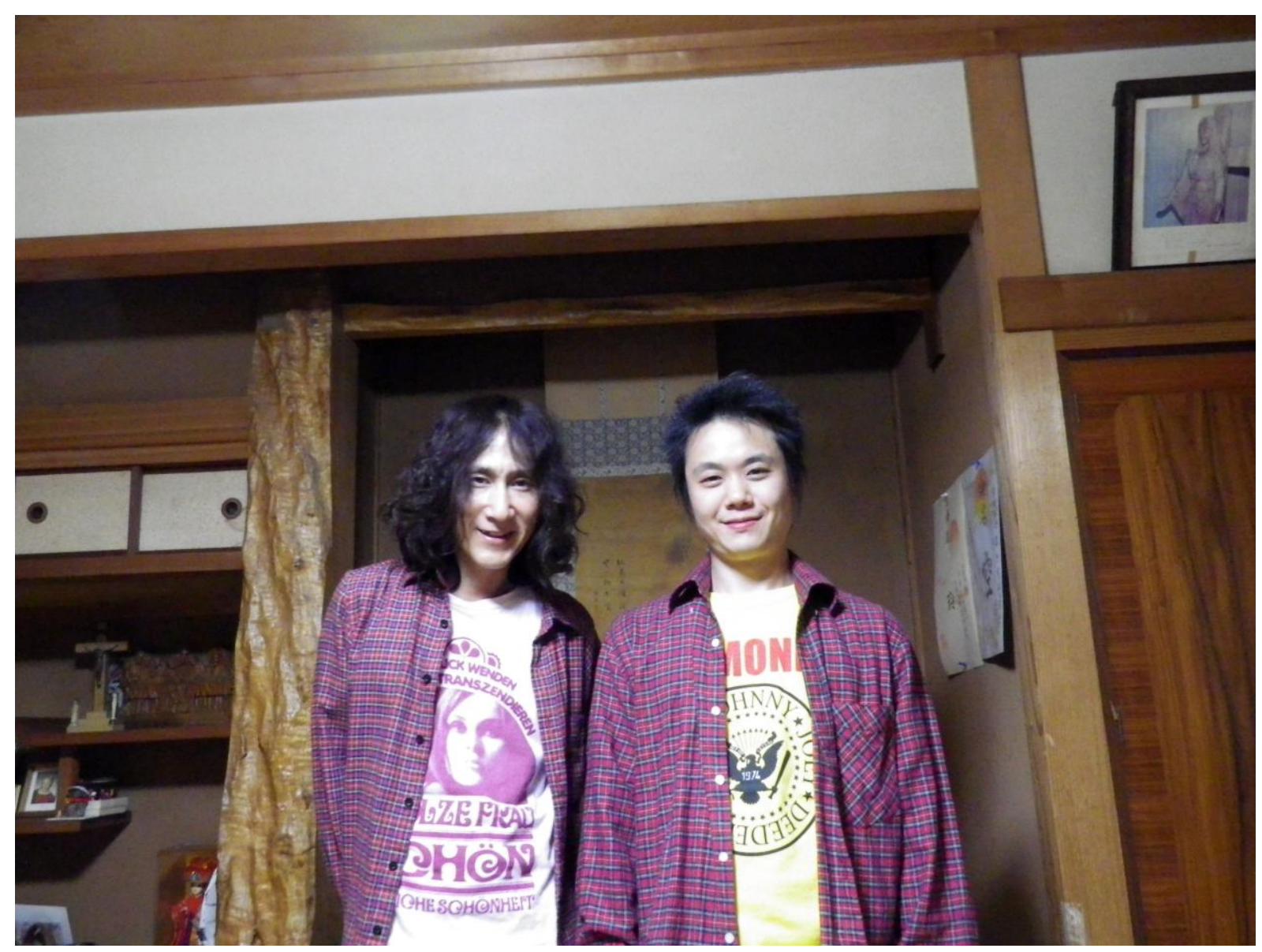

FIGURA 46. Makoto e Bruno. Kagoshima, Japão. 2011 


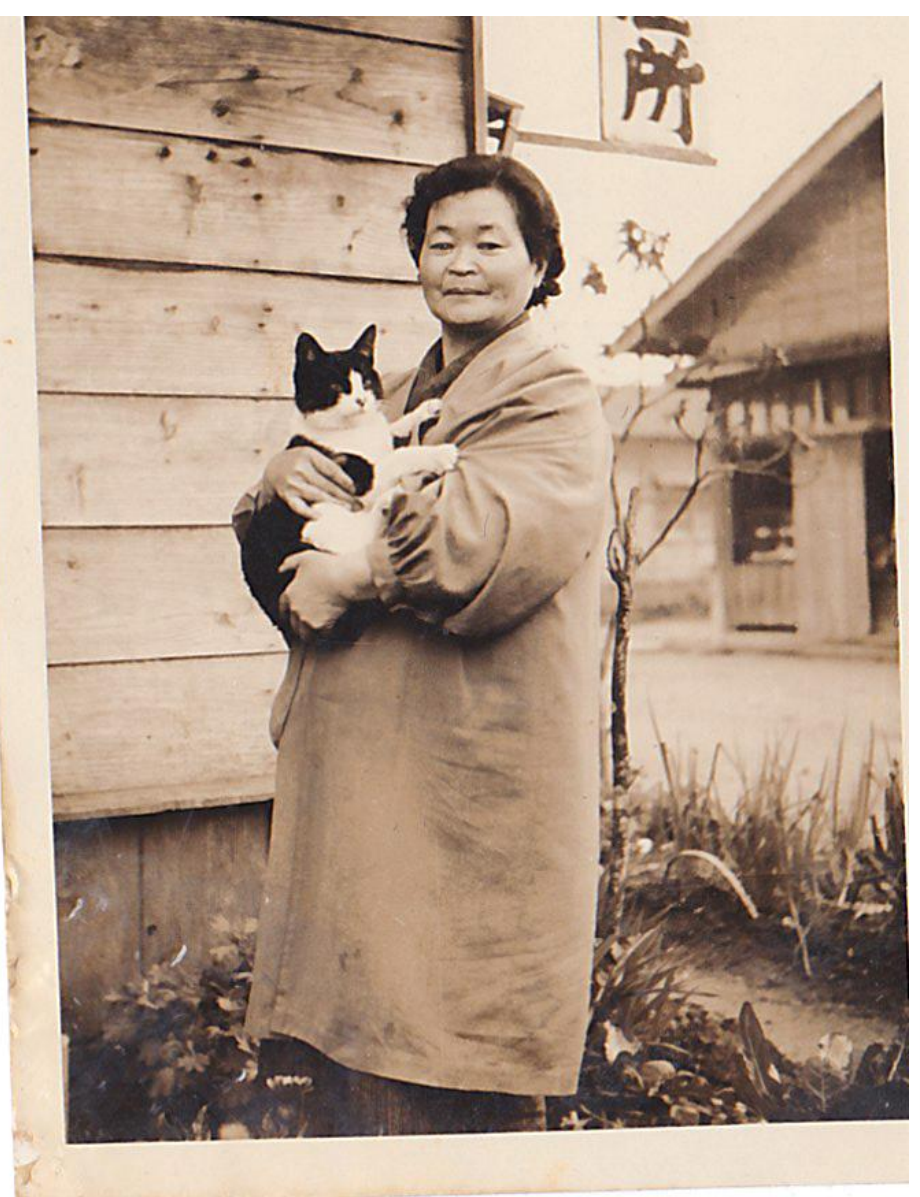

FIGURA 47. Fumi Matsuyama Nagano. Kagoshima, Japão. ca. 1940 


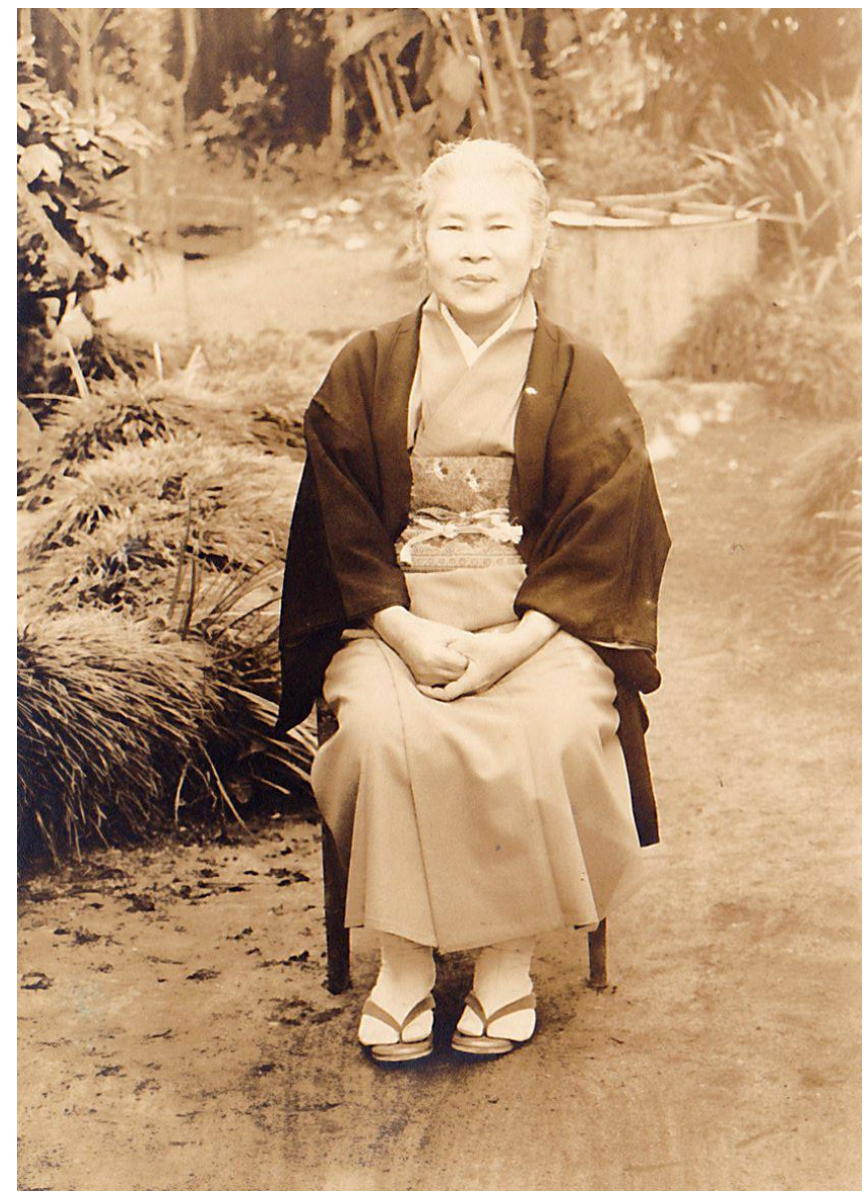

FIGURA 48. Shina Matsuyama. Kagoshima, Japão. ca. 1940 